National Water-Quality Assessment Program

Water-Quality Assessment of Part of the Upper Mississippi River Basin Study Unit, Minnesota and Wisconsin-Nutrients, Chlorophyll $a$, Phytoplankton, and Suspended Sediment in Streams, 1996-98

Water-Resources Investigations Report 02-4287

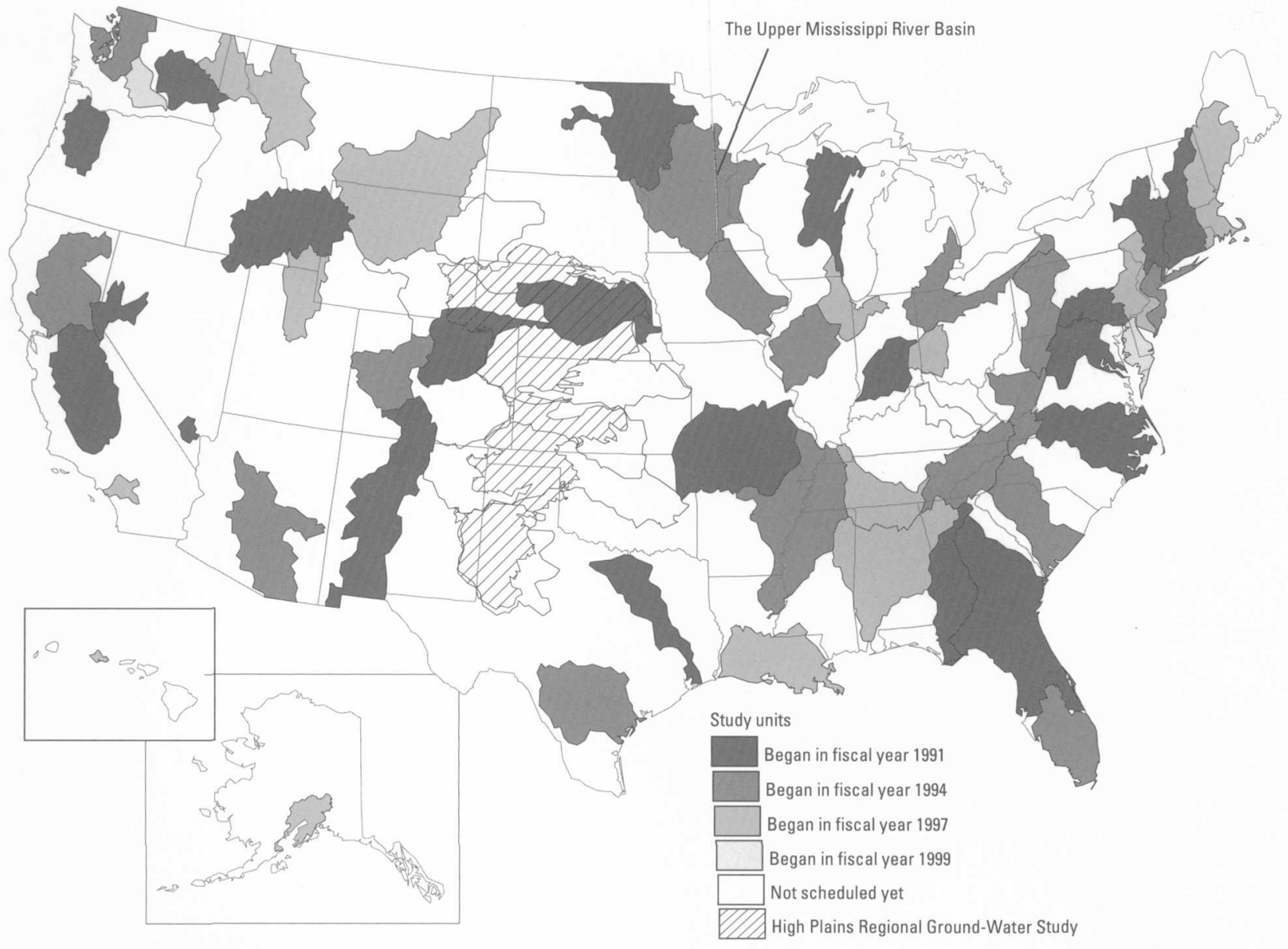

U.S. Department of the Interior

U.S. Geological Survey 

U.S. Department of the Interior

U.S. Geological Survey

\section{Water-Quality Assessment of Part of the Upper Mississippi River Basin Study Unit, Minnesota and Wisconsin-Nutrients, Chlorophyll $a$, Phytoplankton, and Suspended Sediment in Streams, 1996-98}

By S.E. Kroening, K.E. Lee, and R.M. Goldstein

Water-Resources Investigations Report 02-4287

Contribution from the National Water-Quality Assessment Program 


\section{U.S. DEPARTMENT OF THE INTERIOR}

Gale A. Norton, Secretary

U.S. GEOLOGICAL SURVEY

Charles G. Groat; Director

Use of firm, trade, and brand names in this report is for identification purposes only and does not constitute endorsement by the U.S. Geological Survey.

Mounds View, Minnesota, 2003

For additional information write to:

U.S. Geological Survey

District Chief

2280 Woodale Drive

Mounds View, MN 55112

Copies of this report can be purchased from:

\section{U.S. Geological Survey}

Branch of Information Services

Box 25286, MS 517

Federal Center

Denver, CO 80225

Information regarding the National Water-Quality Assessment (NAWQA) Program is available on the Internet via the World Wide Web. You may connect to the NAWQA Home Page using the Universal Resource Locator (URL) at: http://wwwrvares.er.usgs.gov/nawqa/nawqa_home.html

Information about the Upper Mississippi River Basin Project of the NAWQA Program is available at: http://mn.water.usgs.gov/umis/index.html

Water-Resources Investigations Report 02-4287 


\section{FOREWORD}

The U.S. Geological Survey (USGS) is committed to serve the Nation with accurate and timely scientific information that helps enhance and protect the overall quality of life, and facilitates effective management of water, biological, energy, and mineral resources. (http://www.usgs.gov/). Information on the quality of the Nation's water resources is of critical interest to the USGS because it is so integrally linked to the long-term availability of water that is clean and safe for drinking and recreation and that is suitable for industry, irrigation, and habitat for fish and wildlife. Escalating population growth and increasing demands for the multiple water uses make water availability, now measured in terms of quantity and quality, even more critical to the long-term sustainability of our communities and ecosystems.

The USGS implemented the National Water-Quality Assessment (NAWQA) Program to support national, regional, and local information needs and decisions related to waterquality management and policy. (http://water.usgs.gov/nawqa/). Shaped by and coordinated with ongoing efforts of other Federal, State, and local agencies, the NAWQA Program is designed to answer: What is the condition of our Nation's streams and ground water? How are the conditions changing over time? How do natural features and human activities affect the quality of streams and ground water, and where are those effects most pronounced? By combining information on water chemistry, physical characteristics, stream habitat, and aquatic life, the NAWQA Program aims to provide science-based insights for current and emerging water issues and priorities. NAWQA results can contribute to informed decisions that result in practical and effective water-resource management and strategies that protect and restore water quality.

Since 1991, the NAWQA Program has implemented interdisciplinary assessments in more than 50 of the Nation's most important river basins and aquifers, referred to as Study Units. (http://water.usgs.gov/nawqa/nawqamap.html). Collectively, these Study Units account for more than 60 percent of the overall water use and population served by public water supply, and are representative of the Nation's major hydrologic landscapes, priority ecological resources, and agricultural, urban, and natural sources of contamination.

Each assessment is guided by a nationally consistent study design and methods of sampling and analysis. The assessments thereby build local knowledge about water-quality issues and trends in a particular stream or aquifer while providing an understanding of how and why water quality varies regionally and nationally. The consistent, multi-scale approach helps to determine if certain types of water-quality issues are isolated or pervasive, and allows direct comparisons of how human activities and natural processes affect water quality and ecological health in the Nation's diverse geographic and environmental settings. Comprehensive assessments on pesticides, nutrients, volatile organic compounds, trace metals, and aquatic ecology are developed at the national scale through comparative analysis of the Study-Unit findings. (http://water.usgs.gov/nawqa/natsyn.html).

The USGS places high value on the communication and dissemination of credible, timely, and relevant science so that the most recent and available knowledge about water resources can be applied in management and policy decisions. We hope this NAWQA publication will provide you the needed insights and information to meet your needs, and thereby foster increased awareness and involvement in the protection and restoration of our Nation's waters.

The NAWQA Program recognizes that a national assessment by a single program cannot address all water-resource issues of interest. External coordination at all levels is critical for a fully integrated understanding of watersheds and for cost-effective management, regulation, and conservation of our Nation's water resources. The Program, therefore, depends extensively on the advice, cooperation, and information from other Federal, State, interstate, Tribal, and local agencies, non-government organizations, industry, academia, and other stakeholder groups. The assistance and suggestions of all are greatly appreciated.

Robert M. Hirsch

Associate Director for Water 

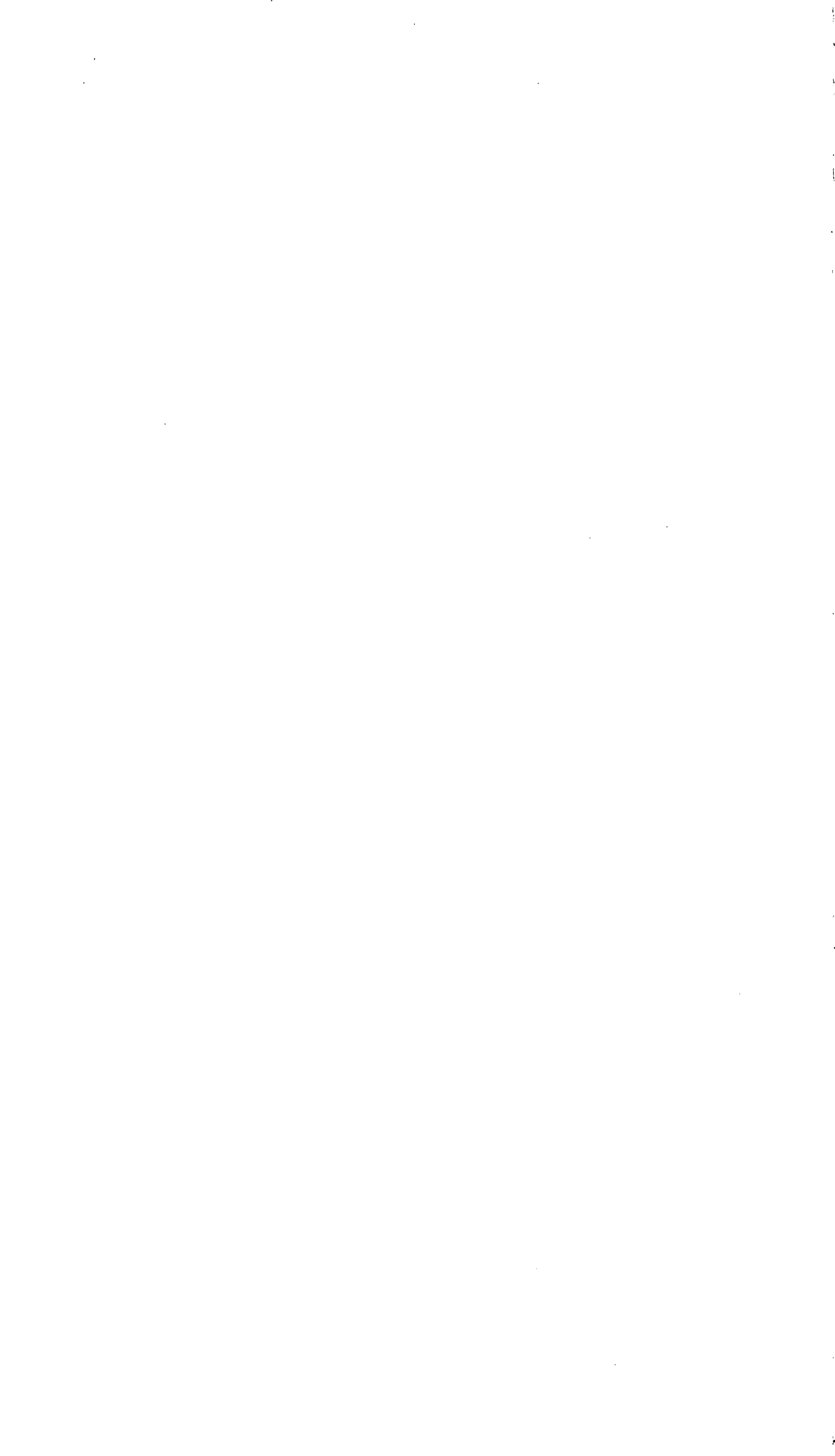

. 


\section{CONTENTS}

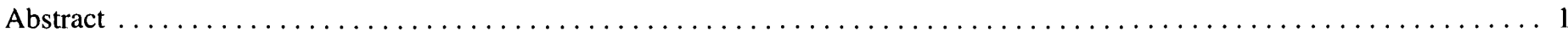

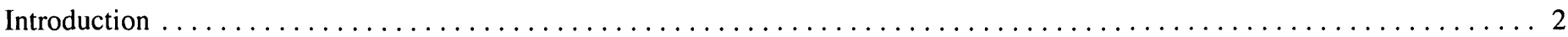

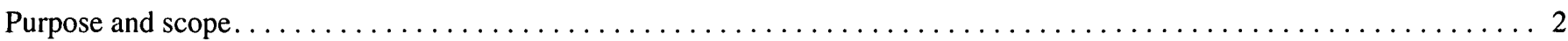

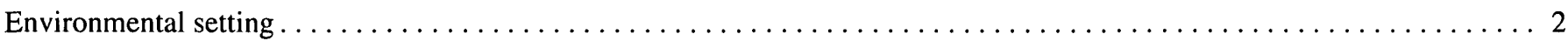

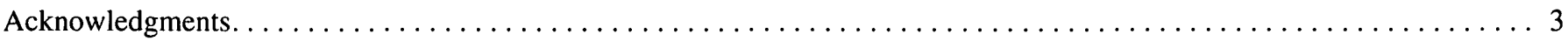

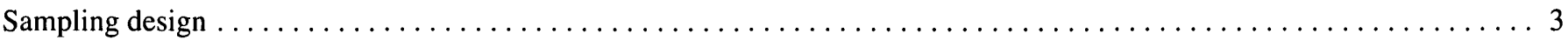

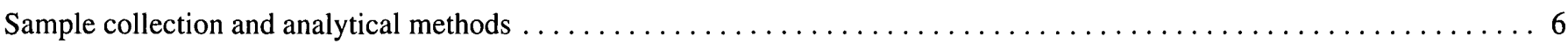

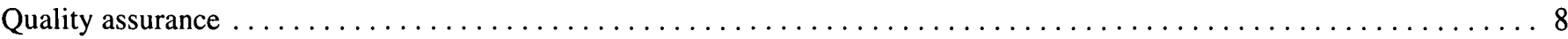

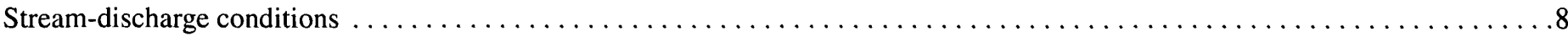

Nutrients, chlorophyll $a$, phytoplankton, and suspended sediment in streams $\ldots \ldots \ldots \ldots \ldots \ldots \ldots \ldots \ldots \ldots \ldots \ldots$

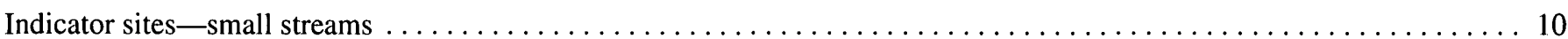

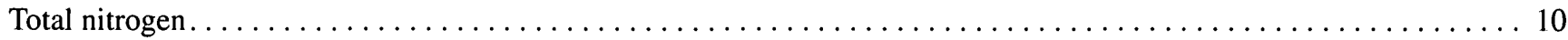

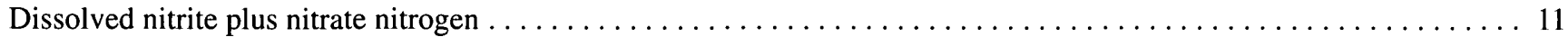

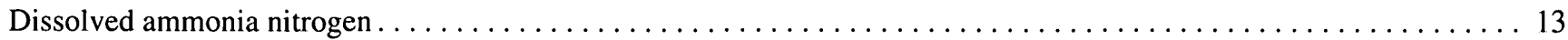

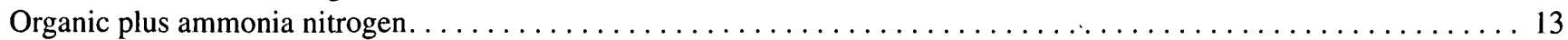

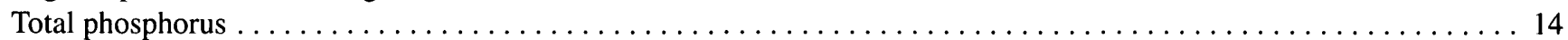

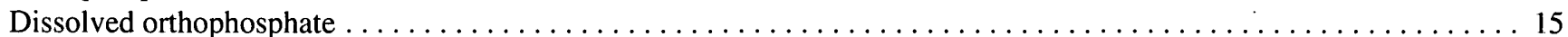

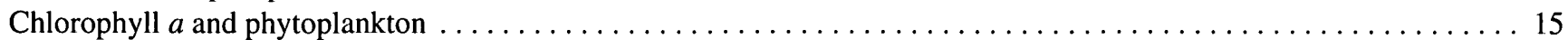

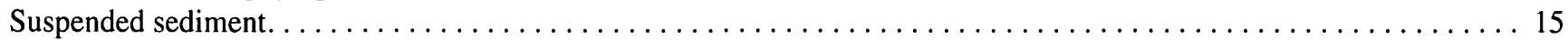

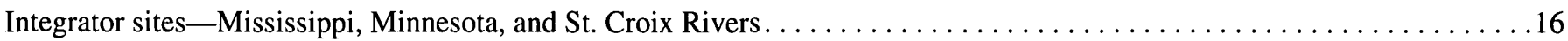

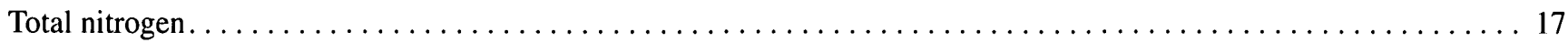

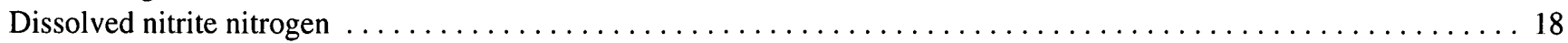

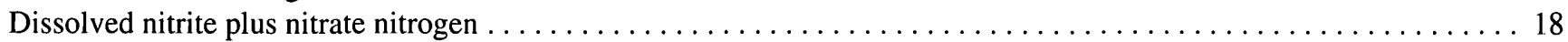

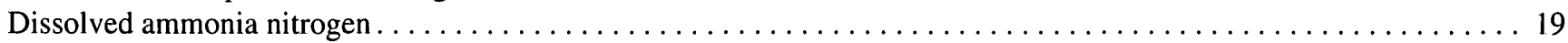

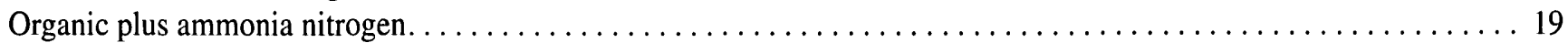

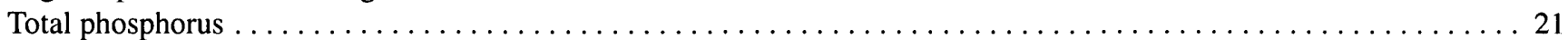

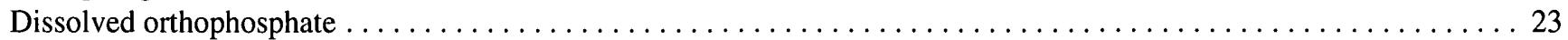

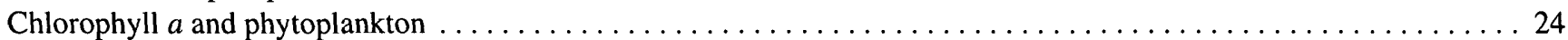

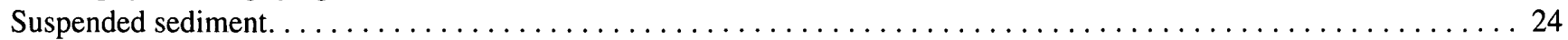

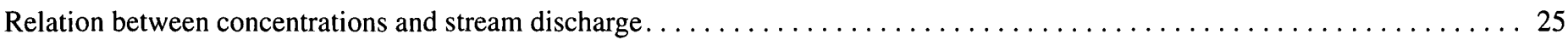

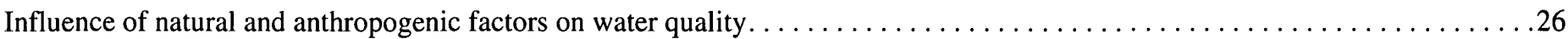

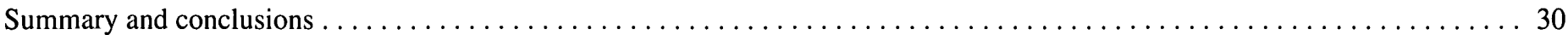

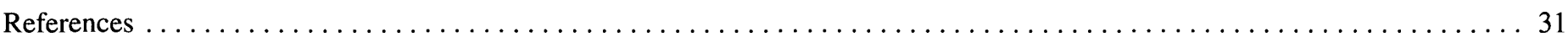

\section{ILLUSTRATIONS}

Figures 1-2. Maps showing:

1. Location of the Upper Mississippi River Basin Study Unit and sampling sites $\ldots \ldots \ldots \ldots \ldots \ldots \ldots \ldots \ldots \ldots$

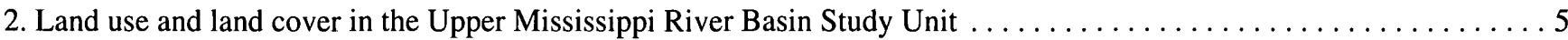

Figures 3-8. Boxplot showing:

3. Total nitrogen concentrations as nitrogen at the indicator sites in the Upper Mississippi River Basin, Study Unit,

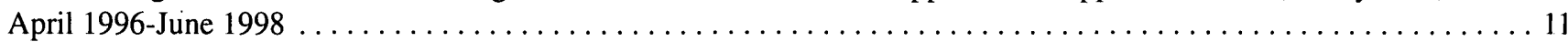

4. Seasonal variations of dissolved nitrite plus nitrate nitrogen concentrations as nitrogen at the indicator sites

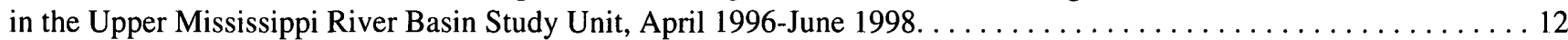

5. Seasonal variations of dissolved ammonia nitrogen concentrations as nitrogen at the indicator sites in the Upper Mississippi River Basin Study Unit, April 1996-June 1998. . . . . . . . . . . . . . . . . . . . . . . . . 13

6. Total phosphorus concentrations at the indicator sites in the Upper Mississippi River Basin Study Unit,

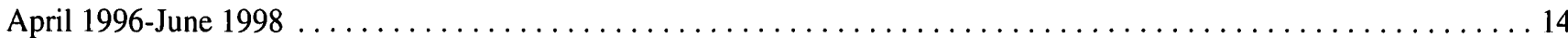

7. Seasonal variations of dissolved orthophosphate concentrations as phosphorus at the indicator sites in the Upper

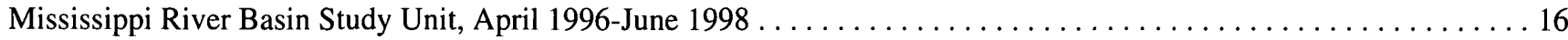

8. Chlorophyll $a$ concentrations during the growing season at the indicator sites in the Upper Mississippi River

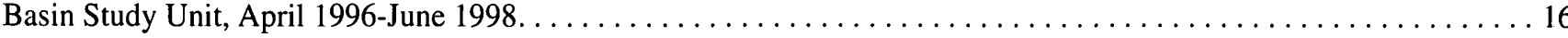




\section{ILLUSTRATIONS--CONTINUED}

Figure 9. Bar chart showing seasonal variations in the phytoplankton community, by algal group, in the North Fork Crow River above Paynesville, Minnesota, and the Little Cobb River near Beauford, Minnesota, in the Upper Mississippi

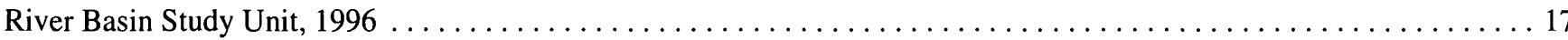

Figures 10-17. Boxplots showing:

10. Suspended-sediment concentrations at the indicator sites in the Upper Mississippi River Basin Study Unit,

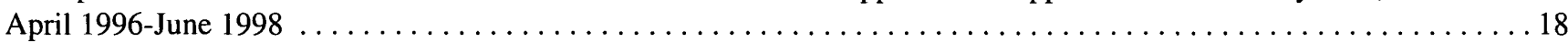

11. Total nitrogen concentrations as nitrogen at the Mississippi, Minnesota, St. Croix River sites in the Upper

Mississippi River Basin Study Unit, April 1996-June 1998 . . . . . . . . . . . . . . . . . . . . . . . . . . 19

12. Dissolved nitrite plus nitrate nitrogen concentrations as nitrogen at the Mississippi, Minnesota, and St. Croix

River sites in the Upper Mississippi River Basin Study Unit, April 1996-June 1998 . . . . . . . . . . . . . . . . 20

13. Seasonal variations in dissolved nitrite plus nitrate nitrogen concentrations as nitrogen at the Mississippi,

Minnesota, and St. Croix River sites in the Upper Mississippi River Basin Study Unit, April 1996-June 1998 . . . . . . . 21

14. Seasonal variations of dissolved ammonia nitrogen concentrations as nitrogen at the Mississippi, Minnesota, and St. Croix River sites in the Upper Mississippi River Basin Study Unit, April 1996-June 1998. . . . . . . . . . . . 22

15. Total phosphorus concentrations at the Mississippi, Minnesota, and St. Croix River sites in the Upper Mississippi

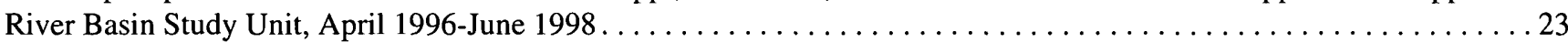

16. Seasonal variations in total phosphorus concentrations at the Mississippi, and Minnesota River sites in

the Upper Mississippi River Basin Study Unit, April 1996-June $1998 \ldots \ldots \ldots \ldots \ldots \ldots \ldots \ldots \ldots \ldots \ldots \ldots \ldots \ldots . . \ldots 25$

17. Dissolved orthophosphate concentrations as phosphorus and chlorophyll $a$ concentrations at the Mississippi,

Minnesota, and St. Croix River sites in the Upper Mississippi River Basin Study Unit, April 1996-June 1998 . . . . . . 26

Figure 18. Bar chart showing seasonal variations in the phytoplankton community, by algal group, in the Mississippi River

near Royalton, Minnesota, and the Minnesota River near Jordan, Minnesota, Upper Mississippi River Basin Study

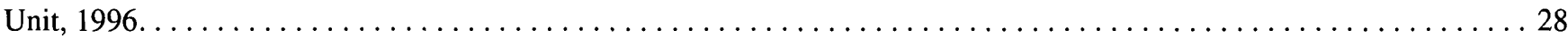

Figure 19. Boxplot showing suspended-sediment concentrations at the Mississippi, Minnesota, and St. Croix River sites in

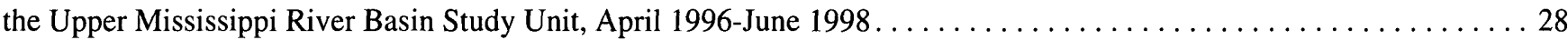

\section{TABLES}

Table 1. Sites sampled for nutrients, chlorophyll $a$, phytoplankton, and suspended sediment in streams of the Upper

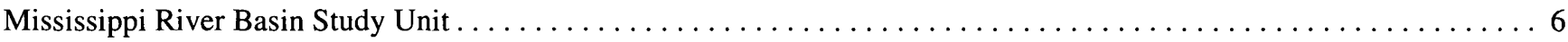

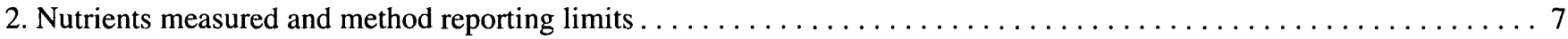

3. Ninety-percent confidence level upper tolerance bounds that specified percentages of concentrations of nitrogen and phosphorus exceeded based on all field blank data $\ldots \ldots \ldots \ldots \ldots \ldots \ldots \ldots \ldots \ldots \ldots \ldots \ldots$

4. Variability in selected nutrient compound and suspended-sediment concentrations $\ldots \ldots \ldots \ldots \ldots \ldots \ldots \ldots \ldots 9$

5. Stream-discharge characteristics for selected streams in the Upper Mississippi River Basin Study Unit . . . . . . . . . 10

6. Total nitrogen loads and yields at the indicator sites in the Upper Mississippi River Basin Study Unit . . . . . . . . . .11

7. Total phosphorus loads and yields at indicator sites in the Upper Mississippi River Basin Study Unit. . . . . . . . . . . . 14

8. Median algal abundance at indicator sites in the Upper Mississippi River Basin Study Unit, June-September 1996. . . . 17

9. Suspended-sediment loads and yields at indicator sites in the Upper Mississippi River Basin Study Unit . . . . . . . . . 18

10. Total nitrogen loads and yields at the Mississippi, Minnesota, and St. Croix River sites in the Upper Mississippi

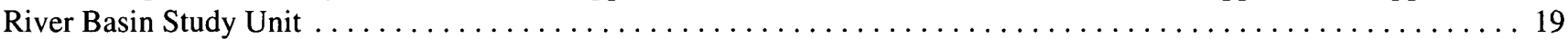

11. Dissolved nitrite plus nitrate nitrogen loads and yields at the Mississippi, Minnesota, and St. Croix River sites in

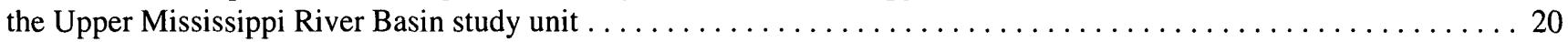

12. Total organic plus ammonia nitrogen loads and yields at the Mississippi, Minnesota, and St. Croix River sites

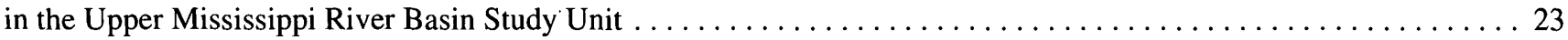

13. Total phosphorus loads and yields at the Mississippi, Minnesota, and St. Croix River sites in the Upper Mississippi

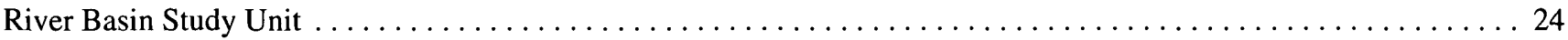

14. Dissolved orthophosphate phosphorus loads and yields at the Mississippi, Minnesota, and St. Croix River sites in

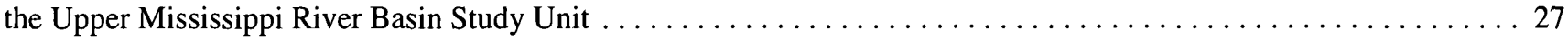

15. Median algal abundance in the Mississippi, Minnesota, and St. Croix Rivers in the Upper Mississippi River Basin

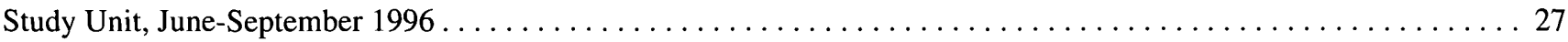




\section{TABLES--CONTINUED}

16. Suspended-sediment loads and yields at the Mississippi, Minnesota, and St. Croix River sites in the Upper Mississippi River Basin Study Unit. . . . . . . . . . . . . . . . . . . . . . . . . . . . . . . 29

17. Kendall tau-b correlation coefficients for nutrient, chlorophyll $a$, and suspended-sediment concentrations and stream discharge, by stream site

\section{CONVERSION FACTORS AND ABBREVIATED WATER QUALITY UNITS}

Multiply

inch (in.)

foot

mile

square mile $\left(\mathrm{mi}^{2}\right)$

tons per day (tons/d)

pounds per square mile per day $\left(\mathrm{lb} / \mathrm{mi}^{2} / \mathrm{d}\right)$

ounce (oz.) by

2.54

0.3048

1.609

2.590

0.9072

0.1751

28.35 to obtain

centimeter

meter

kilometer

square kilometer

megagram

kilograms per square kilometer per day gram

Chemical concentrations of substances in water are given in metric units of milligrams per liter (mg/L) and micrograms per liter $(\mu \mathrm{g} / \mathrm{L})$. Milligrams per liter is a unit expressing the concentration of chemical constituents in solution as mass (milligrams) of solute per unit volume (liter) of water. Micrograms per liter is a unit expressing the concentration of chemical constituents in solution as mass (micrograms) of solute per unit volume (liter) of water. Micrograms per liter are equivalent to milligrams per liter divided by 1,000 . 


\title{
Water-Quality Assessment of Part of the Upper Mississippi River Basin Study Unit, Minnesota and Wisconsin-Nutrients, Chlorophyll a, Phytoplankton, and Suspended Sediment in Streams, 1996-98
}

\author{
By S.E. Kroening, K.E. Lee, and R.M. Goldstein
}

\begin{abstract}
Stream water-quality data from part of the Upper Mississippi River Basin Study Unit (Study Unit) from 1995 through 1998 was used to describe the distribution of nutrients, chlorophyll $a$, phytoplankton, and suspended sediment; and the influence of natural and anthropogenic factors on reported concentrations, loads, and yields. During the study period, streamflows generally were near to greater than average. Agricultural land cover, particularly on tile-drained soils, had the most substantial influence on nutrients, chlorophyll $a$, and suspended sediment in the Study Unit. The greatest concentrations and yields of total nitrogen, dissolved nitrite plus nitrate nitrogen, dissolved nitrite nitrogen, total organic plus ammonia nitrogen, total phosphorus, and suspended sediment were measured in a stream representing agricultural land cover on tile-drained soils. Total nitrogen yields also were about 6 times greater in a stream representing agricultural land cover on tile-drained soils than in a stream representing agricultural land cover on naturally welldrained soils.

Urban-residential land cover also influenced nutrients and suspended sediment in streams in the Study Unit. Concentrations and yields of total nitrogen, dissolved nitrite plus nitrate nitrogen, total organic plus ammonia nitrogen, total phosphorus, dissolved orthophosphate phosphorus (orthophosphate), and suspended sediment in streams representing urban-residential land cover were less than those representing agricultural land cover on tile drained soil, and greater than those on forested land cover.

Nutrients and suspended sediment in the Mississippi, Minnesota, and St. Croix Rivers generally reflect the influence of primary land cover in drainage areas of streams tributary to these rivers. In the Mississippi River, total nitrogen, dissolved nitrite plus nitrate nitrogen, dissolved ammonia nitrogen, total phosphorus, dissolved orthophosphate, and suspended-sediment concentrations and loads increased substantially downstream of the confluence with the Minnesota River at Hastings, Minnesota. Greater concentrations and loads of dissolved orthophosphate in the Mississippi River at Hastings, Minnesota probably were caused by wastewater discharges from the Twin Cities Metropolitan Area (TCMA) and contributions from the Minnesota River. The median dissolved ammonia nitrogen concentration at the Mississippi River at Hastings, Minnesota, based on data collected during this study, was about one-half of the median concentrations previously reported for 1984-93, which can be attributed to reduced ammonia concentrations in municipal wastewater discharged from the TCMA.

In the St. Croix River, total nitrogen, dissolved nitrite plus nitrate nitrogen, and total organic plus ammonia nitrogen concentrations were significantly greater at St. Croix Falls, Wisconsin compared to near Danbury, Wisconsin. All nutrient and suspended-sediment loads and yields in the St. Croix River increased in the downstream direction from near Danbury to St. Croix Falls, Wisconsin.

Most sites had pronounced seasonal variations in dissolved nitrite plus nitrate nitrogen and dissolved ammonia nitrogen concentrations. At most sites, dissolved nitrite plus nitrate nitrogen concentrations were greatest in the winter and spring and least during the summer and fall. In contrast, the greatest dissolved nitrite plus nitrate nitrogen concentrations in the Little Cobb River near Beauford, Minnesota; Minnesota River near Jordan, Minnesota; and Mississippi River at Hastings and Red Wing, Minnesota occurred during the spring and summer. These seasonal variations in dissolved nitrite plus nitrate nitrogen concentrations may be the result of nitrogen cycling in the soils, as well as crop uptake and hydrologic conditions. The greatest concentrations of dissolved ammonia nitrogen at all sites occurred in the winter and spring. The maximum contaminant level for nitrate of 10 milligrams per liter $(\mathrm{mg} / \mathrm{L})$ as nitrogen set by the U.S. Environmental Protection Agency (USEPA) for drinking water was exceeded in 20 percent of the samples analyzed from the Little Cobb River near Beauford, Minnesota, and in 11 percent of the samples analyzed from the Minnesota River near Jordan, Minnesota.

The greatest chlorophyll- $a$ concentrations and algal abundances generally were measured in the Little Cobb River near Beauford, Minnesota; Minnesota River near Jordan, Minnesota; Mississippi River at Hastings, Minnesota; and the Mississippi River at Red Wing, Minnesota. Greater concentrations and algal abundances at these sites may have been the result of increased nitrogen and phosphorus concentrations. Total phosphorus concentrations at these sites most frequently exceeded the goal of $0.1 \mathrm{mg} / \mathrm{L}$ set by the USEPA to prevent eutrophication. Phytoplankton communities at these sites primarily were dominated by blue-green algae during the summer of 1996. In contrast, at most of the other sites, the phytoplankton community was dominated by diatoms.
\end{abstract}




\section{INTRODUCTION}

In 1991, the U.S. Geological Survey (USGS) began full implementation of the National Water-Quality Assessment (NAWQA) Program. Long-term goals of the NAWQA Program are to describe the status of, and trends in, the quality of the Nation's freshwater streams, rivers, and aquifers and to identify the major natural and anthropogenic factors that affect the quality of these resources. Information from the NAWQA Program supports development and evaluation of management, regulatory, and monitoring decisions by other Federal, state, and local agencies that protect, use, and enhance water resources. Goals of the NAWQA Program are achieved through investigations of the Nation's most important river basins and aquifer systems, which are referred to as study units. Study units comprise diverse hydrologic systems of river basins, aquifer systems, or both, and are assessed on a 9-year cycle. Greater than two-thirds of the Nation's freshwater use is present within the study units, and greater than two-thirds of the people served by public water-supply systems live within their boundaries.

The Upper Mississippi River Basin (UMIS) Study Unit (fig. 1) encompasses an area of about $47,000 \mathrm{mi}^{2}$, primarily in the states of Minnesota and Wisconsin.

The Study Unit includes 591 miles of the Mississippi River from its source in northern Minnesota to the outlet of Lake Pepin, a natural lake on the river located in the southeastern part of the Study Unit. The two largest tributaries to the Mississippi River in the Study Unit are the Minnesota and St. Croix Rivers. The Minnesota River drains approximately $17,000 \mathrm{mi}^{2}$ of the southern and western parts of the Study Unit, and the St. Croix River drains approximately $8,000 \mathrm{mi}^{2}$ in the northeastern part. Land cover in the Study Unit is diverse and includes areas of rich agricultural lands, coniferous and deciduous forests, wetlands, lakes, and the seven-county Twin Cities (Minneapolis and St. Paul) metropolitan area (TCMA).

Nitrogen in the Mississippi River are of concern nationally because major municipalities rely on the Mississippi
River as a source of public water supply, and because a zone of hypoxia (dissolved oxygen concentrations less than $2 \mathrm{mg} / \mathrm{L}$ ) that occurs seasonally in the bottom waters of the Gulf of Mexico has been linked to nitrogen loadings from the Mississippi River (Justic and others, 1993; Rabalais and others, 1994; Turner and Rabalais, 1994). Phosphorus in the Mississippi and Minnesota Rivers has received attention due to concerns about algal blooms and fish kills in Lake Pepin during a drought in 1988 (Minnesota Pollution Control Agency, 1989; Metropolitan Waste Control Commission, 1993a; Larson and others, 2002).

Most of the St. Croix River is designated as a National Wild and Scenic Riverway under the Wild and Scenic Rivers Act. National Wild and Scenic Rivers and associated riparian areas are to be protected for the benefit and enjoyment of future generations (Holmberg and others, 1997). The St. Croix River also is managed by the states of Minnesota and Wisconsin to protect the water quality and aquatic biota, and a no-net increase in phosphorus loading goal has been adopted by the St. Croix River Basin Water Resources Planning Team, an interstate, interagency committee formed to address water-quality issues in the basin (Minnesota Environmental Quality Board, 2000).

\section{PURPOSE AND SCOPE}

The purpose of this report is to (1) describe the spatial and temporal distribution of nutrients, chlorophyll $a$, phytoplankton, and suspended sediment in streams of the Upper Mississippi River Basin Study Unit, and (2) describe the influence of natural and anthropogenic factors on concentrations, loads, and yields. Throughout this report, the term nutrients refer to the following nitrogen and phosphorus species: total nitrogen, dissolved nitrite nitrogen, dissolved nitrite plus nitrate nitrogen (nitrate), dissolved ammonia nitrogen, total organic plus ammonia nitrogen, dissolved organic plus ammonia nitrogen, total phosphorus, and dissolved orthophosphate phosphorus (orthophosphate).

This report summarizes the results of water-quality sampling for nutrients, chlorophyll $a$, phytoplankton, and suspended sediment in 12 streams in the Study Unit during water years 1996 through 1998. A water year is the 12 month period from October 1 through September 30 , and is designated by the calendar year in which it ends.

\section{ENVIRONMENTAL SETTING}

The topography of the Study Unit consists of gently rolling hills and plains and a multitude of lakes and wetlands. There are two physiographic provinces within the Study Unit - the Superior Upland province in the northeast and the Central Lowland province in the south and west (Fenneman, 1938). The Superior Upland province consists of flat to hilly moraines and outwash plains. The Western Young Drift Section occupies most of the Central Lowlands province within the Study Unit and is characterized by flat to rolling ground moraines, outwash plains, and glacial lake plains. The Wisconsin Driftless and Dissected Till Plains sections occupy the southeastern part of the Study Unit and are characterized by hilly terrain (Stark and others, 1996).

The underlying bedrock in the Study Unit consists of igneous, metamorphic, and sedimentary rocks that are Precambrian to Cretaceous in age. In the northeastern part of the Study Unit, the bedrock is Precambrian-age sandstones and basalts (Green, 1982). The bedrock in the northern and southwestern parts of the Study Unit principally is Precambrian-age granites and gneisses (Ojakangas and Matsch, 1982) overlain by Cretaceous-age sandstones and shales (Wright, 1972). In the southeastern part of the Study Unit, the bedrock consists of Paleozoic-age sandstones and carbonates overlying Precambrian-age rocks.

The landscape of the Study Unit was shaped during the Pleistocene Epoch, when the Laurentide Ice Sheet covered much of the region. Glaciation during this period occurred as a series of multiple ice advances and retreats which left 
layers of glacial deposits that range in thickness from nearly zero to greater than $600 \mathrm{ft}$ covering most of the Study Unit. Glacial deposits covering the Study Unit include till plains, moraines, and outwash. Till plains and moraines generally are unstratified and primarily consist of an unsorted mixture of clay, silt, sand, and gravel. Outwash material generally is stratified and primarily consists of sorted sand and gravel. The relatively high altitudes of the bedrock in southeastern Minnesota and southwestern Wisconsin deflected ice advances from this area, which is commonly referred to as the Driftless area. The principal lobes from the Laurentide Ice Sheet, which advanced across the Study Unit, were the Superior, Rainy, Des Moines, and Wadena Lobes. The Superior and Rainy Lobes advanced through the northern or northeastern parts of the Study Unit (mostly the St. Croix River Basin), whereas the Des Moines and Wadena Lobes advanced from central Canada into the northwestern and western parts of the Study Unit. Because the Rainy and Superior Lobes primarily advanced over basalts and sandstones, glacial deposits from these ice sheets are principally siliceous. In contrast, the Des Moines and Wadena Lobe advanced over Paleozoic-age limestone and dolomite and are much more calcareous in composition than deposits from the Superior or Rainy Lobes. As a result of differing parent materials, glacial deposits in the Study Unit may be classified by their mineral composition. This classification is complicated in some areas of the Study Unit, such as just north of the TCMA. In these areas, the Des Moines and Superior Lobes both traversed the same location at different times (Ojakangas and Matsch, 1982), so calcareous and siliceous glacial deposits are interbedded.

Land use and land cover in the Study Unit are primarily agriculture, forest, and urban (fig. 2). The primary agricultural crops grown are corn and soybeans. Pigs, cattle, and poultry are the major livestock raised. Urban land cover comprises about 2 percent of the Study Unit, of which 80 percent is within the TCMA.

Most municipal wastewater generated in the Study Unit is treated and discharged to streams (Kroening and
Andrews, 1997). Within the TCMA, municipal wastewater is discharged to the Mississippi, Minnesota, St. Croix, and Vermillion Rivers. Approximately 80 percent of the wastewater generated within the TCMA is discharged to Pool 2 of the Mississippi River (C. Larson, Twin Cities Metropolitan Council, oral commun., 2002). Municipal wastewater treated within the TCMA undergoes additional treatment beyond secondary to further remove suspended solids, and oxygen-demanding substances. Ammonia nitrogen is converted to nitrate nitrogen at municipal wastewater treatment facilities within the TCMA, and phosphorus removal also has been implemented at some of these same facilities. Biological phosphorus removal was implemented on one-quarter of the wastewater treated by the largest municipal wastewater facility on the Mississippi River during 1998 and is anticipated to be implemented fully at this facility by the end of 2003 (Larson and others, 2002). During May 1997, the Metropolitan Council set a goal of removing phosphorus in municipal wastewater effluent to 1 $\mathrm{mg} / \mathrm{L}$ by 2015 (Larson and others, 2002).

The Mississippi River has the largest average streamflow in the Study Unit. Major tributaries to the Mississippi River in the Study Unit include the Crow Wing, Sauk, Crow, Rum, Elk, Minnesota, St. Croix, Cannon, and Vermillion Rivers. The Minnesota and St. Croix Rivers are the largest of these tributaries. Tributaries in the northern part of the Study Unit primarily drain forest areas and areas of mixed forest and agricultural land use and land cover. In contrast, tributaries in the southern part of the Study Unit typically drain areas of row-crop agriculture.

The hydrologic system in the Study Unit has been modified. The U.S. Army Corps of Engineers maintains locks and dams on the Mississippi River. These facilities were constructed primarily in the 1930's to maintain a 9-ft depth in the channel to improve navigation (Minnesota Department of Transportation, 1993). The result of the construction of the locks and dams is that this section of the Mississippi River has been transformed from a free-flowing river into a series of slack-water pools. To enhance crop production, poorly drained soils in the southern and western parts of the Study Unit are artificially drained by an extensive network of drainage ditches and subsurface drain tiles. The drainage ditch systems in part of the tile-drained area were inventoried by Quade and others (1980). Their data indicated the construction of drainage ditches more than doubled the length of the surface fluvial system and rapidly transformed the formerly lake-marsh environment into a geomorphically mature fluvial landscape.

\section{ACKNOWLEDGMENTS}

The authors acknowledge the hard work and dedication of Wallace W. Larson and Todd C. Schmitt of the U.S. Geological Survey who collected most of the data summarized in this report. The authors also express their appreciation to the National Park Service for the support of data collection at the St. Croix River near Danbury, Wisconsin, and the Twin Cities Metropolitan Council for providing river-stage data from Nine Mile Creek.

\section{SAMPLING DESIGN}

This study was designed to assess spatial and temporal distribution of nutrients, chlorophyll $a$, phytoplankton, and suspended sediment in streams in the Study Unit and to evaluate the influence of natural and anthropogenic factors on selected constituents. Five sites were selected to assess more specifically the natural and anthropogenic factors influencing water quality in the Study Unit. This set of sites are termed indicator sites in the NAWQA Program because samples collected at these sites represent influences from fairly homogeneous land cover, physiography, and surficial geology (fig. 1; table 1). Seven sites were selected to assess the three largest rivers in the Study Unit: the Mississippi, Minnesota, and St. Croix (fig. 1, table 1). These sites are termed integrator sites in the NAWQA Program (Gilliom and others, 1995) because samples collected at these sites represent influences from combinations of land covers, point 


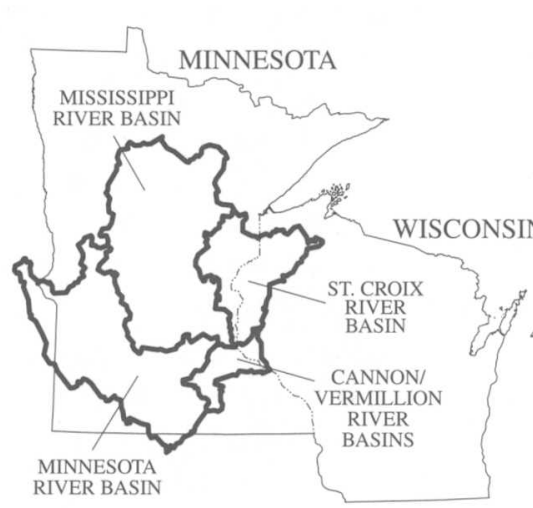

The NAWQA study unit

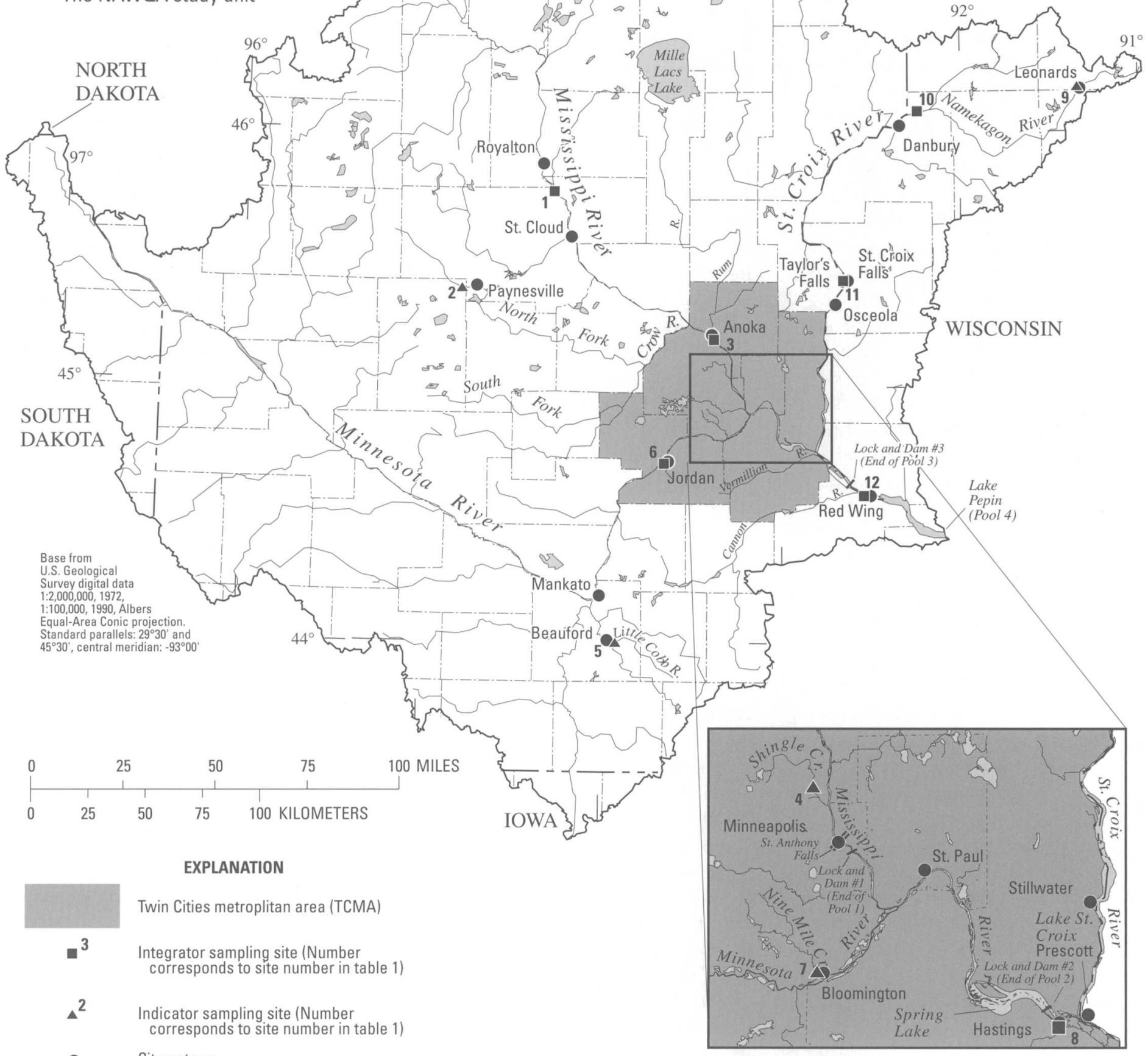

Figure 1. Location of the Upper Mississippi River Basin Study Unit and sampling sites. 


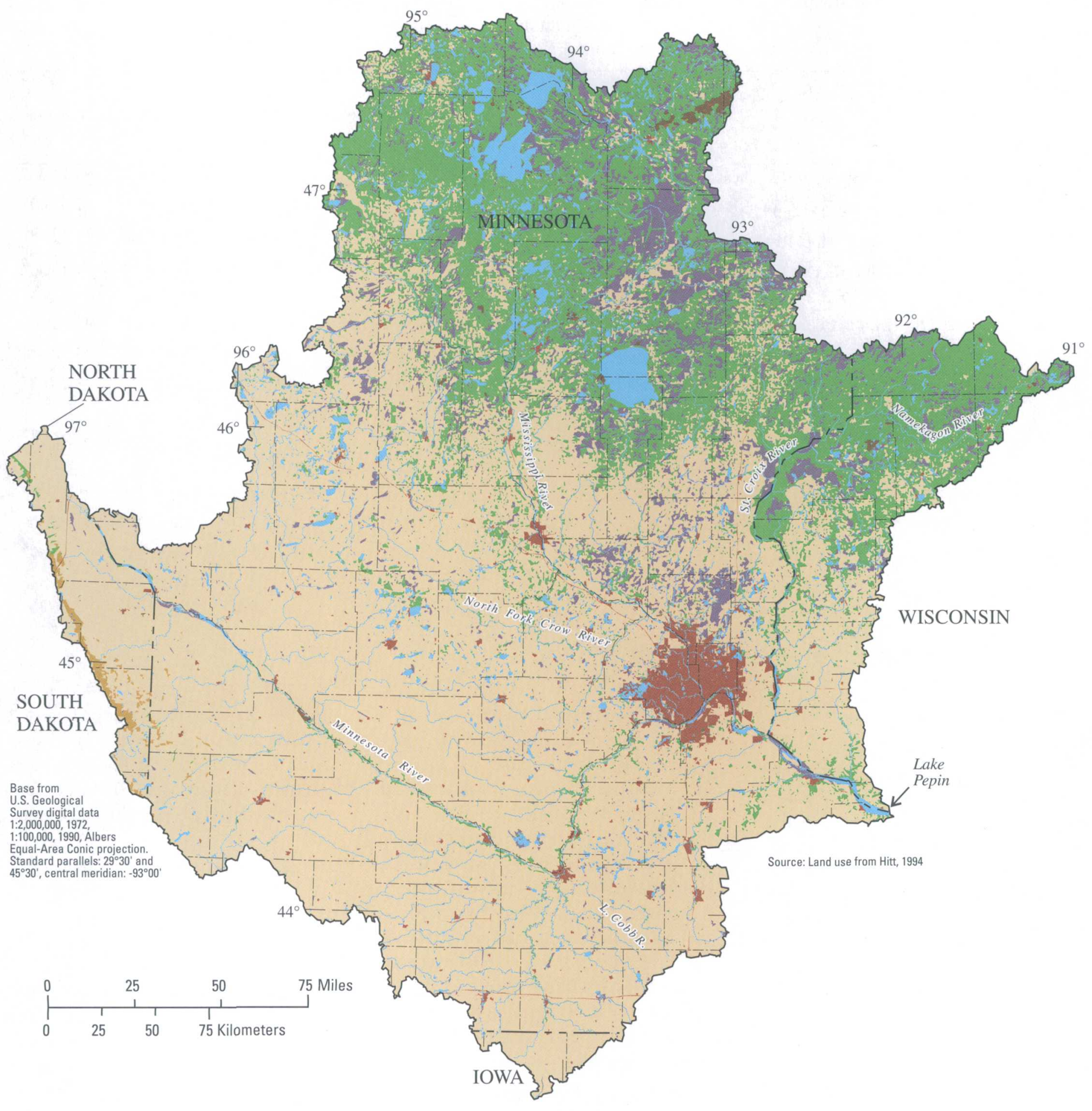

EXPLANATION

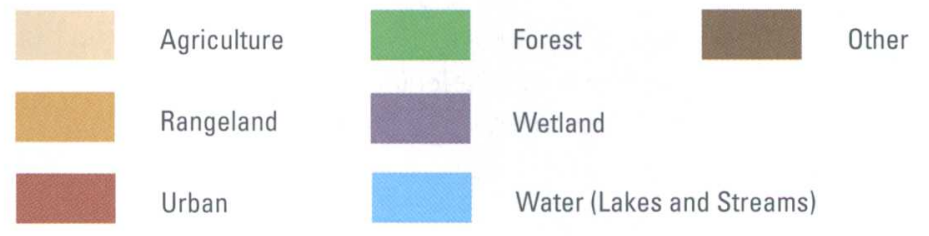

Figure 2. Land use and land cover in the Upper Mississippi River Basin Study Unit. 
Table 1. Sites sampled for nutrients, chlorophyll $a$, phytoplankton, and suspended sediment in streams of the Upper Mississippi River Basin Study Unit

[Sites are listed in downstream order.]

\begin{tabular}{|c|c|c|c|c|c|c|c|}
\hline $\begin{array}{c}\text { Site } \\
\text { number } \\
\text { (shown } \\
\text { in fig. 1) }\end{array}$ & $\begin{array}{l}\text { U.S. Geological } \\
\text { Survey site } \\
\text { identifier }\end{array}$ & Site name & Site type & Land cover & $\begin{array}{l}\text { Drainage area } \\
\text { (square miles) }\end{array}$ & Latitude & Longitude \\
\hline 1 & 05267000 & Mississippi River near Royalton, Minn. & integrator & mixed & 11,600 & $45^{\circ} 51^{\prime} 40^{\prime \prime}$ & $94^{\circ} 21^{\prime} 30^{\prime \prime}$ \\
\hline 2 & 05276005 & North Fork Crow River above Paynesville, Minn. & indicator & agriculture & 232 & $45^{\circ} 22^{\prime} 38^{\prime \prime}$ & $94^{\circ} 47^{\prime} 00^{\prime \prime}$ \\
\hline 3 & 05288500 & Mississippi River near Anoka, Minn. ${ }^{1}$ & integrator & mixed & 19,200 & $45^{\circ} 06^{\prime} 38^{\prime \prime}$ & $93^{\circ} 17^{\prime} 48^{\prime \prime}$ \\
\hline 4 & 05288705 & $\begin{array}{l}\text { Shingle Creek at Queen Avenue in Minneapolis, } \\
\text { Minn. }\end{array}$ & indicator & urban & 28.2 & $45^{\circ} 03^{\prime} 00^{\prime \prime}$ & $93^{\circ} 18^{\prime} 36^{\prime \prime}$ \\
\hline 5 & 05320270 & Little Cobb River near Beauford, Minn. & indicator & agriculture & 130 & $43^{\circ} 59^{\prime} 48^{\prime \prime}$ & $93^{\circ} 54^{\prime} 30^{\prime \prime}$ \\
\hline 6 & 05330000 & Minnesota River near Jordan, Minn. & integrator & agriculture & 16,200 & $44^{\circ} 41^{\prime} 35^{\prime \prime}$ & $93^{\circ} 38^{\prime} 30^{\prime \prime}$ \\
\hline 7 & 05330902 & $\begin{array}{l}\text { Nine Mile Creek near James Circle at } \\
\text { Bloomington, Minn. }\end{array}$ & indicator & urban & 44.6 & $44^{\circ} 48^{\prime} 26^{\prime \prime}$ & $93^{\circ} 18^{\prime} 05^{\prime \prime}$ \\
\hline 8 & 05331580 & $\begin{array}{l}\text { Mississippi River below Lock and Dam } 2 \text { at } \\
\text { Hastings, Minn. }^{2}\end{array}$ & integrator & mixed & 37,000 & $44^{\circ} 44^{\prime} 48^{\prime \prime}$ & $92^{\circ} 51^{\prime} 08^{\prime \prime}$ \\
\hline 9 & 05331833 & Namekagon River at Leonards, Wisc. & indicator & forest & 126 & $46^{\circ} 10^{\prime} 18^{\prime \prime}$ & $91^{\circ} 19^{\prime} 50^{\prime \prime}$ \\
\hline 10 & 05333500 & St. Croix River near Danbury, Wisc. & integrator & forested & 1,580 & $46^{\circ} 04^{\prime} 28^{\prime \prime}$ & $92^{\circ} 14^{\prime} 50^{\prime \prime}$ \\
\hline 11 & 05340500 & St. Croix River at St. Croix Falls, Wisc. & integrator & $\begin{array}{l}\text { forest and } \\
\text { agriculture }\end{array}$ & 6,240 & $45^{\circ} 24^{\prime} 25^{\prime \prime}$ & $92^{\circ} 38^{\prime} 49^{\prime \prime}$ \\
\hline 12 & 05355250 & Mississippi River at Red Wing, Minn. & integrator & mixed & 46,800 & $44^{\circ} 36^{\prime} 36^{\prime \prime}$ & $92^{\circ} 36^{\prime} 36^{\prime \prime}$ \\
\hline
\end{tabular}

'Samples were not collected during February-March and May-July 1997

2 Referred to as Mississippi River at Hastings, in this report.

sources, physiography, and surficial geology.

The stratification process for study design (Stark and others, 1996) included dividing the Study Unit into subareas, based on a combination of natural and anthropogenic factors, and superimposing the drainage basin and aquifer boundaries using a geographic information system (GIS). The Study Unit was stratified at three levels for the stream waterquality sampling component: (1) glacial deposit composition (dominant physiographic provinces); (2) surficial geology (based on texture); and (3) general land use and land cover. The first level of stratification was based on the areal distribution of deposits from glacial lobes that correlate to soil mineralogy, texture, and permeability. Glacial deposits are classified as consisting predominantly of calcareous or siliceous deposits (Hobbs and Goebel, 1992). For each of the dominant provinces of glacial-deposit composition, surficial geologic deposits were subdivided into two groups: (1) till plains, lake deposits, and moraines (fine- grained deposits, which are frequently drained by tiles or ditches); and (2) outwash and alluvium (coarse-grained deposits) (Olcott, 1992). It was assumed that the texture (second level of stratification) of surficial geologic deposits had an influence on the hydrology, water quality, and aquatic biology of streams draining those areas. The third level of stratification was land use and land cover, which was divided into five land cover types (Hitt, 1994): (1) forest, (2) mixed agriculture and forest, (3) agriculture, (4) urban (residential and commercial), and (5) wetlands and lakes.

As a result of this stratification, there were 22 potential stratification combinations within the Study Unit (Stark and others, 1996). Watersheds containing the five most dominant types of stratification combinations were selected for sampling, based on areal extent within the Study Unit. These five stratification combinations represent: (1) agricultural land cover on coarse-grained calcareous deposits, (2) agricultural land cover on fine-grained calcareous deposits, (3) urban-residential land cover on coarsegrained calcareous deposits, (4) urbanresidential land cover on fine-grained calcareous deposits, and (5) forested land cover on coarse-grained siliceous deposits.

Data summarized in this report were collected from 1996 through 1998. Water-quality samples generally were collected monthly and during runoff. The sampling frequency was increased to weekly from April through August 1997 at the sites on Shingle Creek, Little Cobb River, and Nine Mile Creek. Continuous streamflow was computed at most sites using standard USGS techniques (Rantz and others, 1982). At Nine Mile Creek, continuous streamflow was computed using standard USGS techniques based on the stage data collected by the Twin Cities Metropolitan Council.

\section{SAMPLE COLLECTION AND ANALYTICAL METHODS}

Stream water-quality sampling procedures for the NAWQA Program are 
described in detail by Shelton (1994). Most stream-water samples were collected using an equal-width increment and depth-integrated sampling method (Edwards and Glysson, 1988). In this method, samples are composited from approximately 10 equally-spaced vertical transects across the stream and from the water surface to just above the streambed. Most samples from the Mississippi, Minnesota, and St. Croix Rivers were collected from the upstream sides of bridges or boats because of the unwadeable depths of these large rivers. Occasionally, a grab sample was collected using a weighted bottle sampler from near the centroid of flow when ice conditions made other sampling methods unsafe. All samples collected from the St. Croix River at St. Croix Falls, Wisconsin (site 11, table 1) were grab samples because it was not possible to wade the stream or launch a boat at this location. The sampling equipment was constructed of inert materials, such as teflon or polyethylene. Clean-sampling protocols also were used to minimize the possible introduction of contaminants during sampling and handling (Shelton, 1994). All samples were composited and split using a Teflon cone splitter (Capel and Larson, 1996). Samples to be analyzed for dissolved nutrient concentrations were filtered using 0.45 micrometer $(\mu \mathrm{m})$ pore size encapsulated filters. Samples analyzed to determine total nutrient concentrations were not filtered. In addition to collecting stream-water samples, measurements of water temperature, $\mathrm{pH}$, spe- cific conductance, dissolved oxygen, and alkalinity were done in the field.

Stream-water samples were shipped to the USGS National Water-Quality Laboratory (NWQL) in Colorado for analysis of nutrients and to the USGS Sediment Laboratory in Iowa for analysis of suspended-sediment concentrations. At the NWQL, samples were analyzed to determine the concentrations of seven nutrient compounds (table 2) using colorimetry as described by Patton and Truitt (1992) and Fishman (1993). Chlorophyll $a$ analyses were done by the USGS in Mounds View, Minnesota using USEPA method 445 (U.S. Environmental Protection Agency, 1992). Phytoplankton were identified and enumerated by the Philadelphia Academy of Natural Sciences in Pennsylvania.

Ranges in nutrient, suspended sediment, and chlorophyll- $a$ concentrations among sites are shown graphically in this report using standard boxplots (Helsel and Hirsch, 1992). Censored values (values below the method reporting limit) were displayed in boxplots by setting each censored value to the method reporting limit. Boxplots are not shown for the site on the Mississippi River near Anoka because this site was not sampled consistently throughout the study. Differences in the period of record sampled may bias comparisons of constituent concentrations among sites, especially if there are substantial variations with season or hydrologic conditions. Differences in concentrations among sites were tested for statistical significance using the
Kruskal-Wallis test (Helsel and Hirsch, 1992). The test compares median values between groups of data. When used to make multiple comparisons, the overall error rate was controlled as described by Helsel and Hirsch (1992). The significance level of 0.05 , or $p$ value less than 0.05 , was the criteria used to designate statistical significance. Throughout this report, the term "significant" refers to differences in concentrations determined to be statistically significant. Seasonal variations in concentrations at the sites were analyzed using boxplots by season. In this analysis, winter is December through February; spring is March through May; summer is June through August; and fall is September through November.

The stream load is the mass of a constituent, such as nitrate, that has been carried past a point on a stream in a given amount of time, usually 1 year. Stream loads commonly are used to determine the relative contribution of constituents to a larger river or lake from tributaries and point sources. Yield is the stream load divided by the drainage area, and is the mass of a constituent being transported per unit area of the watershed. Yields often are used to determine relative contributions of constituents.

Stream loads were calculated using the version 96.04 of the ESTIMATOR program (G. Baier, T. Cohn, and E. Gilroy, U.S. Geological Survey, written commun., 1993). This program uses an adjusted maximum likelihood technique to compute daily constituent loads as a

Table 2. Nutrients analyzed and method reporting limits

\begin{tabular}{lcc}
\hline \multicolumn{1}{c}{ Nutrient } & $\begin{array}{c}\text { U.S. Geological Survey } \\
\text { parameter code }\end{array}$ & $\begin{array}{c}\text { Method reporting limit (milli- } \\
\text { grams per liter) }\end{array}$ \\
\hline Dissolved nitrite nitrogen & 00613 & 0.01 \\
Dissolved nitrite plus nitrate nitrogen & 00631 & 0.05 \\
Dissolved ammonia nitrogen & 00608 & 0.02 \\
Total organic plus ammonia nitrogen & 00625 & ${ }^{1} 0.10-0.20$ \\
Dissolved organic plus ammonia nitrogen & 00623 & ${ }^{1} 0.10-0.20$ \\
Total phosphorus & 00665 & 0.05 \\
Dissolved orthophosphate phosphorus & 00671 & 0.01 \\
\hline
\end{tabular}

\footnotetext{
1 The method reporting limit for this constituent was lowered to 0.10 milligrams per liter as nitrogen on November 10, 1997 (Peter Rogerson, U.S. Geological Survey, written commun., National Water-Quality Laboratory Technical Memorandum 97.10, June 20, 1997)
} 
function of streamflow and season. A minimum-variance unbiased estimator also was used to account for the retransformation bias incurred by transforming logarithmic-predicted loads back to the original units. A 95-percent prediction interval was calculated for each load estimate. The prediction interval is the confidence interval for prediction of an estimate of a value, and is used to quantify the uncertainty associated with an estimated load. Water-quality data from 1996 through 1998 were used to calibrate the load model. Loads were computed using streamflow data from water years 1997 and 1998.

Total nitrogen concentrations and loads were calculated by summing total organic plus ammonia and dissolved nitrite plus nitrate nitrogen concentrations and loads because total nitrogen was not directly measured. There were sufficient data to estimate constituent loads for the Mississippi River near Anoka. Total nitrogen concentrations were not calculated because the period of record was different from the other sites.

Constituent loads were not computed for Nine Mile Creek for water year 1998. The stage-discharge relation at this site was unstable throughout the sampling period. No streamflow measurements were made at this site after water-quality sampling ended in June 1998. As a result, the accuracy of the continuous streamdischarge data could not be verified from July through September 1998.

Relations between nutrient, chlorophyll- $a$, and suspended-sediment concentrations and streamflow were analyzed by computing Kendall tau correlation coefficients (Helsel and Hirsch, 1992, p. 212) and visually examining plots of constituent concentrations and streamflow. For all correlations, the criteria for statistical significance was less than 0.05 . Correlation coefficients measure the strength of the association between two variables. Two variables may be correlated because they share the same underlying cause, but correlation does not provide evidence of a causal relation between two variables.

\section{QUALITY ASSURANCE}

Information on bias and variability is necessary to properly interpret waterquality data. Bias and variability may exist in a data set as a result of sample collection, processing, or laboratory procedures. Bias is the systematic error inherent in a method and may be either positive or negative. Positive bias may result from the introduction of contaminants into the sample during sampling or processing procedures, laboratory analysis, exposure to airborne gases and particulates, or due to inadequately cleaned sample collection or analytical equipment. Variability is the random error in independent measures of the same quantity. In water-quality data, variability results from errors inherent in sample collection, processing procedures, and laboratory analysis.

Field blank data collected as part of this study and a synoptic survey of water quality and aquatic communities in streams draining agricultural areas conducted for the NAWQA Program (Stark and others, 1999) were used to assess contamination bias in the data. A field blank is a water sample that is intended to be free of the analytes of interest. Field blank data collected as part of the synoptic survey were used to increase sample size for quality assurance evaluation for this study. These quality-control data were directly comparable to the data collected as part of this study because the sample collection, processing, and analytical procedures were identical. Field blank samples were prepared at the sampling site as described by Mueller and others (1997). Briefly, field blank samples were prepared by pouring water certified by the USGS to be free of nutrients and sediment through all of the sample collection and splitting equipment as if an environmental sample were being processed. These samples were then filtered, preserved, and shipped to the laboratory according to standard NAWQA sampling procedures (Shelton, 1994).

Contamination bias was quantified by constructing an upper tolerance bound on the field-blank concentration data. A tolerance bound is a statistical interval which contains a specified proportion of a sampled population. In analyses of water-quality data, tolerance bounds often are constructed to determine a limiting concentration that most values do not exceed, which is called an upper tolerance bound. Because the distributions of the field-blank concentration data were highly skewed, distribution-free methods (Hahn and Meeker, 1991) were used to calculate upper tolerance bounds. Upper tolerance bounds of contamination bias, based on field blanks are presented in table 3. For example, there is a greater than 90 percent confidence that contamination is less than or equal to $0.07 \mathrm{mg} / \mathrm{L}$ of dissolved ammonia nitrogen in 85 percent of all samples.

Variability in the water-quality data was determined by analyzing results from split replicate samples. Split replicate samples assess the variability introduced by sample processing, handling, and laboratory analytical procedures. Split replicates were prepared by dividing a single volume of sample water into two subsamples. Each of the subsamples was then processed and analyzed separately.

The variability in the nutrient and suspended-sediment concentration data was computed by calculating the mean relative standard deviation for each of the constituents. The mean relative standard deviation is defined as the standard deviation divided by the mean concentration (table 4).

\section{STREAM-DISCHARGE CONDITIONS}

The amount and concentration of constituents in a stream may be affected by stream-discharge conditions. In cases where a constituent is supplied by a relatively constant source, such as a wastewater treatment facility or ground-water inflow, increases in streamflow as the result of the addition of rain water usually results in lesser constituent concentrations because of dilution. In contrast, when a constituent generally is supplied to a stream by erosion or overland flow, an increase in precipitation (and streamflow) may cause increased constituent concentrations due to runoff. At some locations, constituent concentrations may 
Table 3. Ninety-percent confidence level upper tolerance bounds that specified percentages of concentrations of nitrogen and phosphorus exceeded based on all field blank data.

\begin{tabular}{|c|c|c|c|c|c|}
\hline \multirow[b]{2}{*}{ Compound } & \multirow[b]{2}{*}{$\begin{array}{l}\text { Number of field } \\
\text { blank samples }\end{array}$} & \multirow[b]{2}{*}{$\begin{array}{l}\text { Method reporting limit } \\
\text { (milligrams per liter) }\end{array}$} & \multicolumn{3}{|c|}{$\begin{array}{l}\text { 90-percent confidence level upper tolerance bound } \\
\text { (milligrams per liter) }\end{array}$} \\
\hline & & & $\begin{array}{l}70 \text { percent of } \\
\text { samples }\end{array}$ & $\begin{array}{l}80 \text { percent of } \\
\text { samples }\end{array}$ & $\begin{array}{l}85 \text { percent of } \\
\text { samples }\end{array}$ \\
\hline Dissolved nitrite plus nitrate nitrogen & 19 & 0.05 & 0.06 & 0.06 & 0.07 \\
\hline Dissolved ammonia nitrogen & 19 & 0.02 & 0.04 & 0.04 & 0.07 \\
\hline Total organic plus ammonia nitrogen & 19 & $0.1-0.2$ & $<0.20$ & 0.13 & 0.24 \\
\hline Total phosphorus & 19 & 0.05 & $<0.05$ & $<0.05$ & $<0.05$ \\
\hline Dissolved orthophosphate phosphorus & 19 & 0.01 & 0.02 & 0.02 & 0.02 \\
\hline
\end{tabular}

be affected by both relatively constant sources and runoff from the land surface.

Streamflows in the Study Unit were near or greater than average during water years 1996 through 1998 compared to mean annual discharges from the last 25 years (water years 1974 through 1998) (table 5). Streamflows generally were above average in water years 1996 and 1997 and near average in water year 1998. Many streams in the Study Unit had near record streamflows during April 1997, due to an abrupt warming trend that melted an unusually large snowpack. These types of conditions also led to greater than average streamflows in the St. Croix River Basin during April 1996. Major thunderstorms during July 1997 caused greater than average streamflows in most of the streams throughout the Study Unit. Thunderstorms also caused greater than average streamflows in the St. Croix River during April, May, and July 1996 and in the Little Cobb River near Beauford, Minnesota (not shown) and Minnesota River near Jordan, Minnesota during June 1996.

\section{NUTRIENTS, CHLOROPHYLL A, PHYTOPLANKTON, AND SUSPENDED SEDIMENT IN STREAMS}

Natural and anthropogenic activities produce nitrogen and phosphorus in the environment. These elements occur naturally in the atmosphere and as part of soils, rocks, vegetation, and biota. The largest natural reservoir of nitrogen is the atmosphere, which consists of 78 percent nitrogen gas. Phosphorus occurs naturally in minerals such as apatite (Hem, 1985). However, phosphorus minerals are not commonly present in the Study Unit. One of the primary uses of nitrogen and phosphorus compounds is to manufacture fertilizers. Historically, phosphorus compounds have been used to increase the cleaning power of detergents, but state legislation has restricted their use. A 1976 Minnesota law restricts the amount of phosphorus in laundry detergents to 0.5 percent (by weight) and in dishwashing detergents to 11 percent (by weight) (Mary Hayes, Minnesota Pollution Control Agency, written com- mun., 1993). In Wisconsin, phosphorus in laundry detergents was limited to 0.5 percent (by weight) on January 1, 1984 (Litke, 1999).

The USEPA (1986) has established national water-quality criteria for un-ionized ammonia $\left(\mathrm{NH}_{3}\right)$. In drinking water supplies, the USEPA (2000) has established a maximum contaminant level (MCL) for nitrate of $10 \mathrm{mg} / \mathrm{L}$ as nitrogen. Nitrate concentrations greater than 10 $\mathrm{mg} / \mathrm{L}$ in drinking water can cause a potentially fatal condition called methemoglobinemia, or blue-baby syndrome, usually in infants. Criteria for un-ionized ammonia are dependent upon stream $\mathrm{pH}$ and temperature. Un-ionized ammonia, which exists in equilibrium with ammonium $\left(\mathrm{NH}_{4}^{+}\right)$, is toxic to fish and other aquatic life. National water-quality criteria have not been established for phosphorus compounds in surface water, but to prevent nuisance plant growth in streams and other flowing waters not discharging directly to lakes or impoundments, the USEPA (1986) has established a desired goal of $0.1 \mathrm{mg} / \mathrm{L}$.

Elevated concentrations of nutrients in streams and lakes can result in

Table 4. Variability in selected nutrient compound and suspended-sediment concentrations

\begin{tabular}{lcc}
\hline \multicolumn{1}{c}{ Compound } & Number of replicate samples & $\begin{array}{c}\text { Mean relative standard deviation } \\
\text { (milligrams per liter) }\end{array}$ \\
\hline Dissolved nitrite plus nitrate nitrogen & 17 & 0.043 \\
Dissolved ammonia nitrogen & 17 & 0.086 \\
Total organic plus ammonia nitrogen & 17 & 0.057 \\
Total phosphorus & 17 & 0.073 \\
Dissolved orthophosphate phosphorus & 17 & 0.027 \\
Suspended sediment & 11 & 0.140 \\
\hline
\end{tabular}


Table 5. Stream-discharge characteristics for selected streams in the Upper Mississippi River Basin Study Unit

\begin{tabular}{|c|c|c|c|c|c|c|}
\hline \multirow[b]{2}{*}{$\begin{array}{l}\text { Site number } \\
\text { (shown in fig. 1) }\end{array}$} & \multirow[b]{2}{*}{$\begin{array}{c}\text { U.S. Geological } \\
\text { Survey site } \\
\text { identifier }\end{array}$} & \multirow[b]{2}{*}{ Site name } & \multicolumn{4}{|c|}{ Mean annual streamflow (cubic feet per second) } \\
\hline & & & $\begin{array}{c}\text { Water year } \\
1996\end{array}$ & $\begin{array}{c}\text { Water year } \\
1997\end{array}$ & $\begin{array}{c}\text { Water year } \\
1998\end{array}$ & $\begin{array}{l}\text { Water years } \\
1974-1998\end{array}$ \\
\hline 1 & 05267000 & Mississippi River near Royalton, Minn. & 7,790 & 8,320 & 5,540 & 5,620 \\
\hline 3 & 05288500 & Mississippi River near Anoka, Minn. & 11,850 & 12,440 & 8,940 & 9,480 \\
\hline 6 & 05330000 & Minnesota River near Jordan, Minn. & 7,270 & 10,400 & 5,760 & 5,880 \\
\hline 10 & 05333500 & St. Croix River near Danbury, Wisc. & 1,690 & 1,610 & 1,190 & 1,370 \\
\hline 11 & 05340500 & St. Croix River at St. Croix Falls, Wisc. & 6,350 & 5,480 & 3,750 & 5,000 \\
\hline
\end{tabular}

eutrophication. Eutrophication is the excessive growth of aquatic plants and algae. Chlorophyll $a$ is a photosynthetic pigment and is used as an indicator of the amount of algae in a water body. Excessive algal growth can have several adverse consequences. Eutrophic water bodies become aesthetically unpleasing for recreational activities such as swimming and boating. Increased abundance of certain species of algae result in foul smelling and tasting water, which may ultimately increase water treatment costs if the water is used for drinking. When these plants and algae become so abundant that shading prohibits photosynthesis, some of the plants and algae die. The decomposition of the plant material uses dissolved oxygen, which may become depleted in the water and cause the death of fish and other aquatic life.

Suspended-sediment concentrations in streams may be increased by land-use practices that encourage erosion. Increased concentrations of suspended sediment make the water less desirable for swimming and other recreational activities and also reduce the amount of light reaching aquatic vegetation. Deposition of sediment on fish-spawning areas may reduce the successful development of fish eggs. Sediment also may be a carrier of other contaminants, such as phosphorus, trace elements, and trace hydrophobic organic contaminants.

\section{INDICATOR SITES-SMALL STREAMS}

Five streams (indicator sites) were assessed to determine the influence agricultural, urban-residential, or forested land cover had on water quality in the
Study Unit. Agricultural and urban-residential indicator streams (table 1) were located in areas of coarse- or fine-grained calcareous and coarse-grained siliceous deposits. To improve crop productivity, portions of the Study Unit are artificially drained by an extensive network of subsurface tile drains and drainage ditches. Information on the density of tile drains was not readily available for the North Fork Crow and Little Cobb Basins. However, a soil survey that includes most of the Little Cobb River Basin indicated artificial drainage enhances or is required for crop production for many soil types in the basin (Cummins, 1965). Conversely, Anderson (1989) reported that very sandy soils of the North Fork Crow Basin allow for rapid infiltration of precipitation and rapid transport of dissolved constituents to ground water. None of the indicator sites sampled were greatly influenced by municipal or industrial wastewater effluent.

\section{Total Nitrogen}

Total nitrogen concentrations at indicator sites were greatest at the Little Cobb River (fig. 3). The median concentrations at this site were about four times greater than those from the North Fork Crow River, the site with the next greatest median concentration. Median concentrations among all the indicator sites were determined to be significantly different. The order of statistical significance (beginning with the site determined to have the greatest total nitrogen median concentration) was as follows: Little Cobb River, North Fork Crow River, Shingle Creek, Nine Mile Creek, and Namekagon River. These results indicated agricultural and urban land cover, espe- cially agricultural land-use on tile-drained soils, influenced total nitrogen concentrations in the Study Unit.

Yields followed a pattern similar to concentrations (table 6). Total nitrogen yields were about 6 times greater at the Little Cobb River site compared to those at the North Fork Crow River site. The differences in total nitrogen concentrations and yields between these two agricultural indicator sites probably were not the result of differences in fertilizer or animal manure applications. Fertilizer nitrogen application to the drainage area upstream from the North Fork Crow and Little Cobb River sites was computed based on sales data from 1997 (D.L. Lorenz, U.S. Geological Survey, oral commun., 1999). Nitrogen in livestock manure was computed based on animal populations reported in the 1997 Census of Agriculture (B. Ruddy, U.S. Geological Survey, written commun., 1999). Nitrogen fertilizer applications and livestock manure generation (expressed as tons of nitrogen) were similar in the drainage areas of the Little Cobb River (103.4 tons/square mile) and North Fork Crow River sites (97.2 tons/square mile). Nitrogen fertilizer applications were greater in the drainage area of the Little Cobb River site (80.1 tons/square mile) compared to the drainage area of the North Fork Crow River site (56.9 tons/square mile). In contrast, nitrogen in livestock manure in the drainage area of the North Fork Crow River site (40.3 tons/square mile) was almost twice that at in the drainage area of the Little Cobb River site (23.3 tons/square mile). Total nitrogen yields probably were greater from the Little Cobb River because nitrate contained in soil water was transported to streams by 


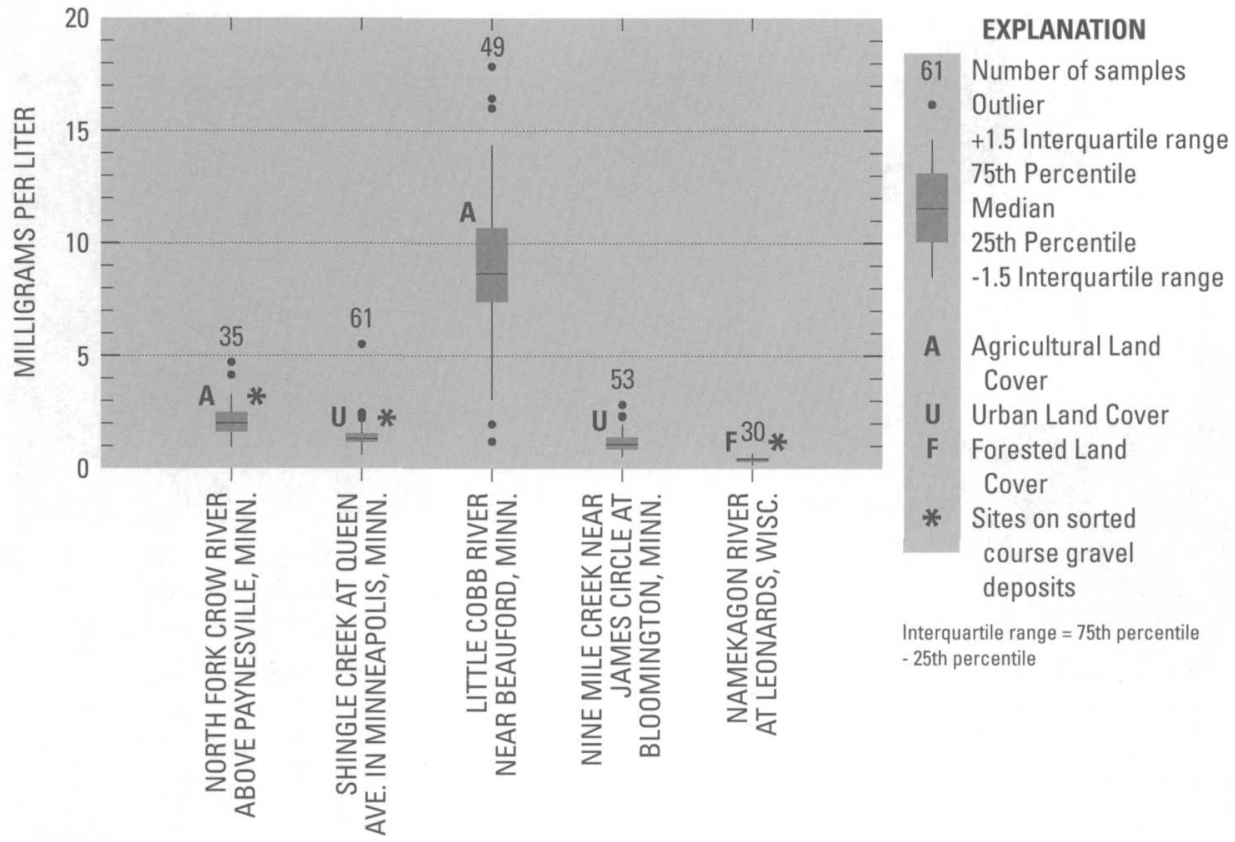

Figure 3. Total nitrogen concentrations as nitrogen at the indicator sites in the Upper Mississippi River Basin Study Unit, April 1996-June 1998.

tile drainage. Another source of nitrogen to the Little Cobb River may have been from the mineralization of the organicrich mollisol soils to nitrate, which may not have been as important in the drainage area of the North Fork Crow River. Burkart and James (1999) computed nitrate mineralized from soil organic matter was the largest potential nitrate source in the Mississippi River Basin, exceeding both commercial fertilizer and livestock manure inputs. Areas with the greatest amount of potentially mineralizable nitrate from soil organic matter include the Minnesota River Basin.

\section{DISSOLVED NITRITE PLUS NITRATE NITROGEN}

Dissolved nitrite plus nitrate nitrogen concentrations and yields generally had similar spatial and temporal distribution as total nitrogen. The order of statistical significance for median dissolved nitrite plus nitrate nitrogen concentrations (beginning with the site determined to have the greatest median concentration) was as follows: Little Cobb River, North Fork Crow River, Shingle Creek and Nine Mile Creek, Namekagon River. At the Little Cobb River site, about one-half of the concentrations ranged between 6 and $9 \mathrm{mg} / \mathrm{L}$. At most of the other sites, concentrations typically were less than 1 $\mathrm{mg} / \mathrm{L}$. The MCL for nitrate of $10 \mathrm{mg} / \mathrm{L}$ as $\mathrm{N}$ set by the USEPA for drinking water was exceeded in 20 percent of the samples analyzed from the Little Cobb River. No exceedances of the MCL for nitrate were measured at the other indicator sites.

Nitrite nitrogen composed a small proportion of nitrite plus nitrate concentrations. Dissolved nitrite nitrogen concentrations ranged from below the method reporting limit $(0.01 \mathrm{mg} / \mathrm{L})$ to $0.18 \mathrm{mg} / \mathrm{L}$. Median concentrations ranged from less than $0.01 \mathrm{mg} / \mathrm{L}$ at the Namekagon River site to $0.04 \mathrm{mg} / \mathrm{L}$ at the Little Cobb River site. Dissolved nitrite nitrogen was detected in 96 percent of the samples from the Little Cobb River site and 95 percent of the samples from the Shingle Creek site. In contrast, dissolved nitrite nitrogen was detected in only 23 percent of the samples from the Namekagon River.

Seasonal variations in dissolved nitrite plus nitrate nitrogen concentrations varied among the indicator sites (fig. 4). At the Little Cobb River site, the median concentration was greatest in the spring and least in the fall. Greater dissolved nitrite plus nitrate nitrogen concentrations during the spring at the Little Cobb River site may be attributed to the transport of nitrate applied as fertilizer or derived from the mineralization of soil organic matter. Lesser concentrations during the fall at the Little Cobb and North Fork Crow River sites probably are due to assimilation by crops and other plants during the summer growing season and reduced precipitation. The greatest dissolved nitrite plus nitrate nitrogen con-

Table 6. Total nitrogen loads and yields at the indicator sites in the Upper Mississippi River Basin Study Unit

[Sites are listed in downstream order; $\mathrm{lb} / \mathrm{d}$, pounds per day; $\mathrm{lb} / \mathrm{mi}^{2} / \mathrm{d}$, pounds per square mile per day; $\mathrm{NC}$, not computed due to insufficient data]

\begin{tabular}{|c|c|c|c|c|c|c|}
\hline \multirow[b]{2}{*}{$\begin{array}{l}\text { Site number } \\
\text { (shown in } \\
\text { fig. 1) }\end{array}$} & \multirow[b]{2}{*}{ Site name } & \multirow[b]{2}{*}{ Land cover } & \multicolumn{2}{|c|}{ Water year 1997} & \multicolumn{2}{|c|}{ Water year 1998} \\
\hline & & & $\begin{array}{c}\text { Mean daily } \\
\text { load } \\
\text { (lb/d) }\end{array}$ & $\begin{array}{c}\text { Mean daily } \\
\text { yield } \\
\left(\mathrm{lb} / \mathrm{mi}^{2} / \text { day }\right)\end{array}$ & $\begin{array}{c}\text { Mean daily } \\
\text { load } \\
\text { (lb/d) }\end{array}$ & $\begin{array}{l}\text { Mean daily } \\
\text { yield } \\
\left(\mathrm{lb} / \mathrm{mi}^{2} / \mathrm{d}\right)\end{array}$ \\
\hline 2 & North Fork Crow River above Paynesville, Minn. & agriculture & 1,884 & 8.1 & 1,116 & 4.8 \\
\hline 4 & Shingle Creek at Queen Avenue in Minneapolis, Minn. & urban-residential & 161 & 5.7 & 97 & 3.5 \\
\hline 5 & Little Cobb River near Beauford, Minn. & agriculture & 6,538 & 50.3 & 5,270 & 40.5 \\
\hline 7 & Nine Mile Creek near James Circle at Bloomington, Minn. & urban-residential & 241 & 5.4 & NC & $\mathrm{NC}$ \\
\hline 9 & Namekagon River at Leonards, Wisc. & forest & 367 & 2.9 & 272 & 2.2 \\
\hline
\end{tabular}




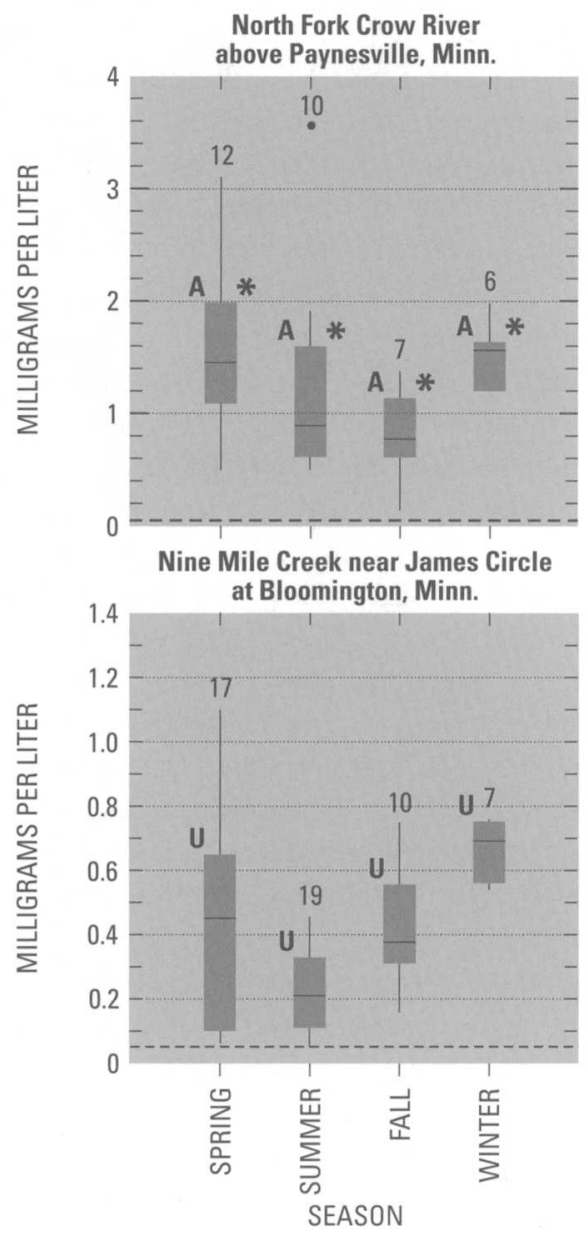

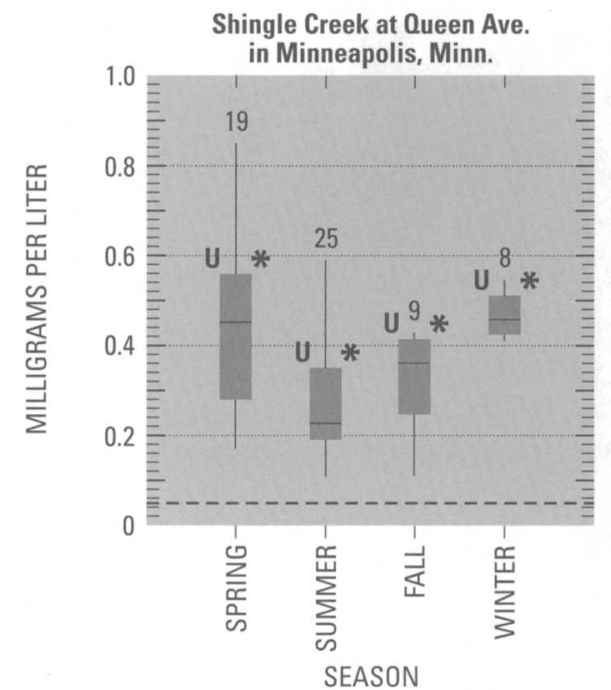

EXPLANATION
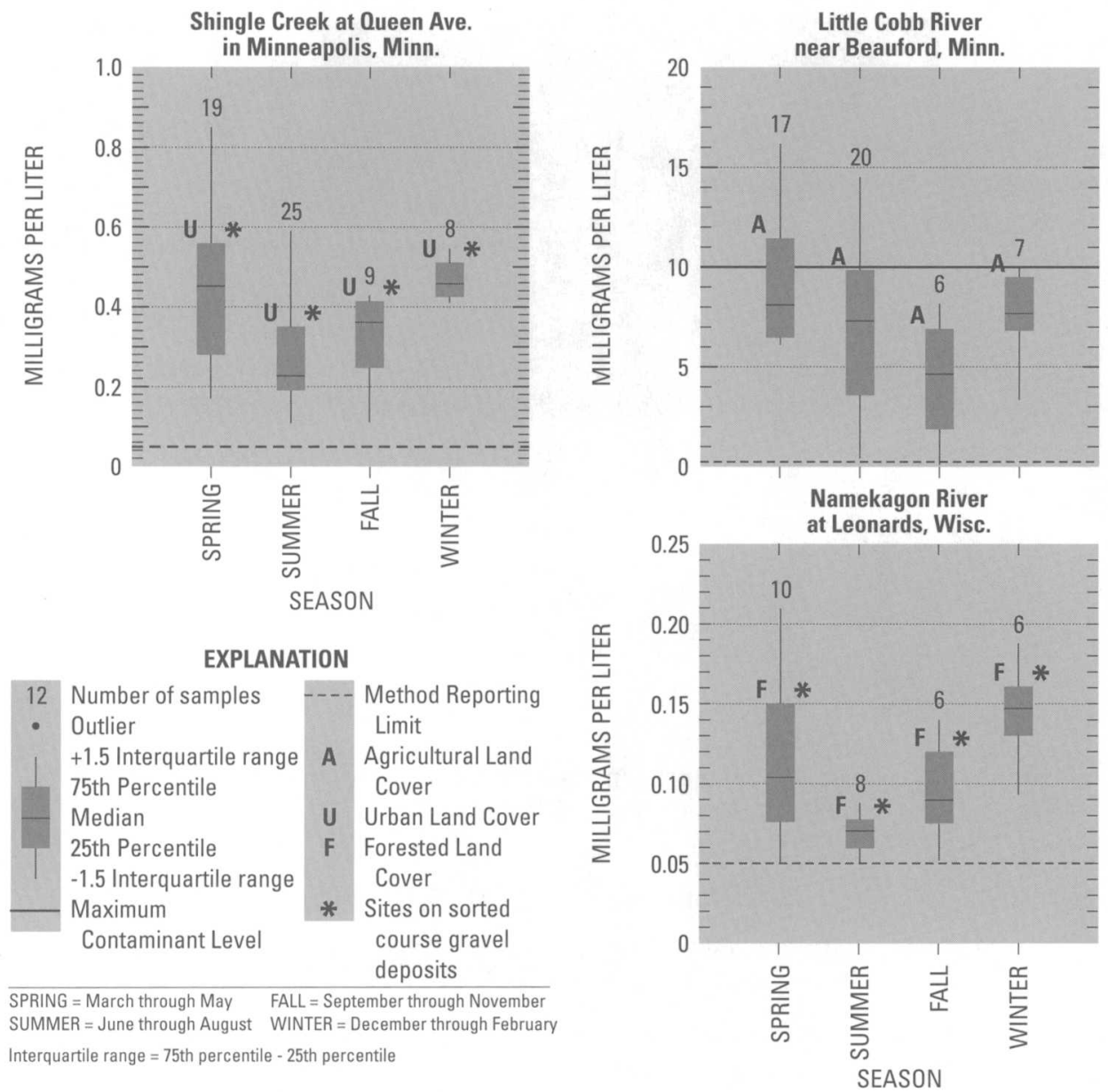

Figure 4. Seasonal variations of dissolved nitrite plus nitrate nitrogen concentrations as nitrogen at the indicator sites in the Upper Mississippi River Basin Study Unit, April 1996-June 1998 (note differences in concentration scales).

centrations occurred during the winter at the North Fork Crow River, Nine Mile Creek, and the Namekagon River sites may be attributed to reduced assimilation by terrestrial and aquatic plants due to lower temperatures and plant dormancy. At the North Fork Crow River site, increased dissolved nitrite plus nitrate nitrogen concentrations during winter also may result from ground-water inflow. Within the Study Unit, the greatest dissolved nitrite plus nitrate nitrogen concentrations were in surficial aquifers (Kroening and Andrews, 1997), such as those underlying the North Fork Crow River.

Dissolved nitrite plus nitrate nitrogen concentrations at the Little Cobb River site generally were greater in water year 1998 than water year 1997. The median and maximum concentrations at this site in water year 1997 were 6.9 and 13.1 $\mathrm{mg} / \mathrm{L}$, respectively, and the median and maximum concentrations in water year 1998 were 7.4 and $16.2 \mathrm{mg} / \mathrm{L}$, respectively. Differences in concentrations between these years may have been the result of reduced fertilizer applications, differences in terrestrial nitrate cycling, or dilution. Precipitation and streamflow were greater in water year 1997 than 1998. Wetter conditions in water year 1997 may have made the agricultural fields less accessible, and as a result less fertilizer may have been applied. Some processes that affect nitrate concentrations on the land surface, such as denitrification or soil mineralization, also are influenced by soil moisture. Greater soil moisture in water year 1997 would have resulted in lower oxygen concentrations in the soil, producing conditions more conducive for denitrification and less conducive for soil mineralization. Less fertilizer applications and soil mineralization and more denitrification would have resulted in less nitrate on the land surface available to be transported to streams. Concentrations in streams also may have been diluted by greater precipitation in water year 1997. However, a previous study of stream-water quality in the Minnesota River Basin (Payne, 1994) indicated dilution of dissolved nitrite plus nitrate nitrogen concentrations does not typically occur in this area.

Dissolved nitrite plus nitrate nitrogen composed about 25 percent of the nitrogen load at sites in the urban-residential and forested areas (Shingle Creek, Nine Mile Creek, and Namekagon River). In contrast, dissolved nitrite plus nitrate nitrogen composed greater proportions in 
agricultural areas (approximately 50 percent of the total nitrogen load at the North Fork Crow River site, and about 90 percent of the total nitrogen load at the Little Cobb River site).

\section{Dissolved Ammonia Nitrogen}

Dissolved ammonia nitrogen concentrations were significantly greater at the Shingle Creek site compared to the other indicator sites. The order of statistical significance for median dissolved ammonia nitrogen concentrations (beginning with the site determined to have the greatest median concentrations) was as follows: Shingle Creek, North Fork Crow River and Nine Mile Creek, Little Cobb River and Namekagon River.

Low dissolved oxygen concentrations at the Shingle Creek site indicated reducing conditions in the streambed sedi- ments. Under reducing conditions, organic nitrogen is converted to ammonia in the sediments, which could account for greater ammonia concentrations in the creek. Lesser dissolved ammonia nitrogen concentrations at the Little Cobb River site may be due to uptake by phytoplankton. Chlorophyll- $a$ concentrations during the growing season (June through September) were greatest in this stream compared to the other indicator sites (see section on chlorophyll $a$ ).

Median dissolved ammonia nitrogen concentrations were greatest during winter at the North Fork Crow River, Shingle Creek, Little Cobb River, and Nine Mile Creek sites (fig. 5), probably due to less biological uptake, which is consistent with results from an analysis of retrospective stream water-quality data in the Study Unit (Kroening and Andrews,
1997). There also were some elevated concentrations during the spring, especially at the North Fork Crow River site. At the Namekagon River site dissolved ammonia nitrogen concentrations were near method reporting limits (not shown).

\section{Organic Plus Ammonia Nitrogen}

Total organic plus ammonia nitrogen concentrations and yields varied among the sites. The order of statistical significance for median organic plus ammonia nitrogen concentration (beginning with the site determined to have the greatest median concentration) was as follows: Little Cobb River, Shingle Creek, North Fork Crow River and Nine Mile Creek, Namekagon River.

Particulate forms of organic and ammonia nitrogen generally were more
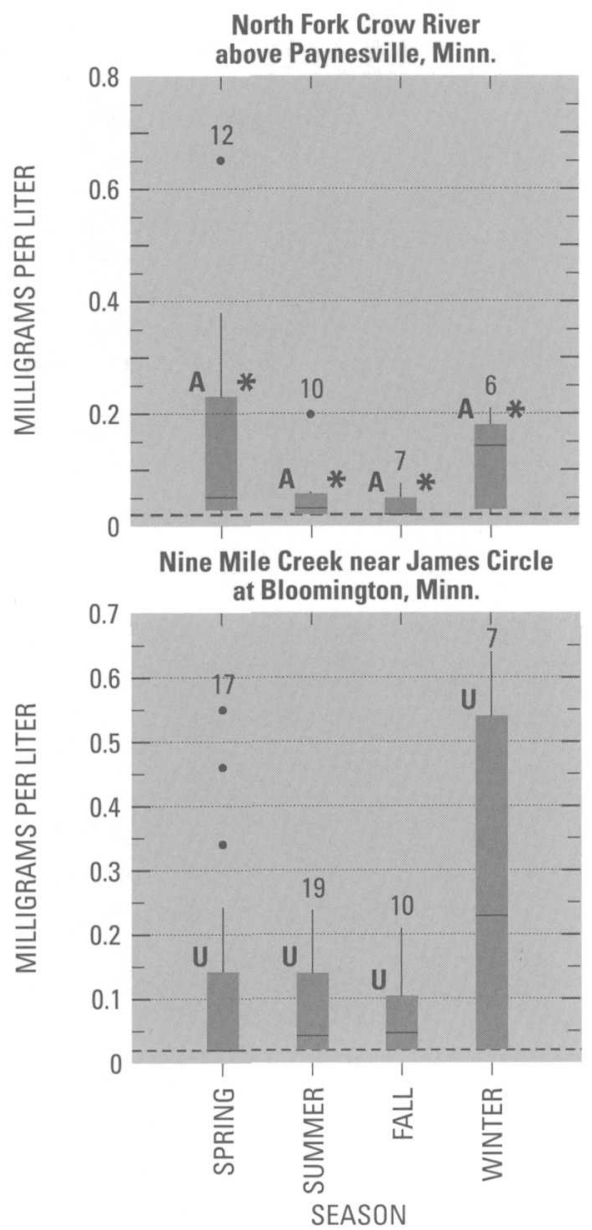

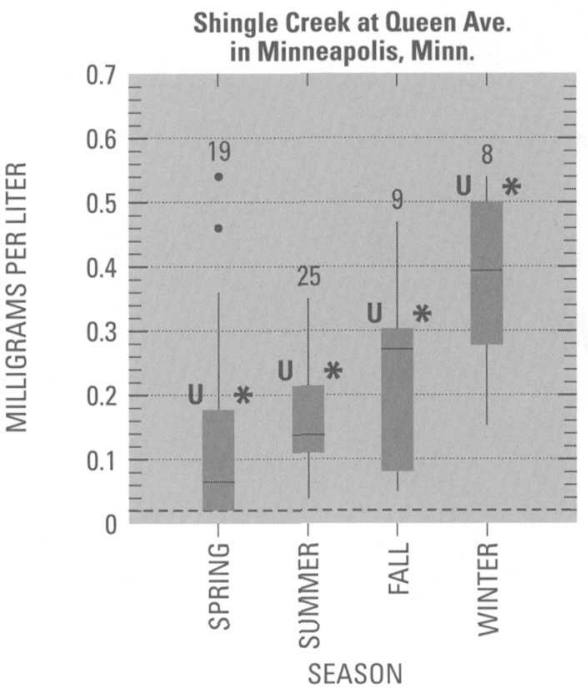

Figure 5. Seasonal variations of dissolved ammonia nitrogen concentrations as nitrogen at the indicator sites in the Upper Mississippi River Basin Study Unit, April 1996-June 1998 (note difference in concentration scales). 
important at the Shingle Creek and Little Cobb River sites. In these two streams, particulate organic plus ammonia nitrogen generally composed 35 to 45 percent of the total organic plus ammonia nitrogen concentration. In contrast, particulate organic plus ammonia nitrogen generally composed 22 to 28 percent of the total organic plus ammonia nitrogen concentration at the North Fork Crow River, Nine Mile Creek, and Namekagon River sites.

The greater total organic plus ammonia nitrogen concentrations and yields at the Little Cobb River site may have resulted from the erosion and transport of the organic-rich mollisol soils that are in this part of the Study Unit (Stark and others, 1996). The utilization of ammonia or nitrate as a nutrient by phytoplankton in the Little Cobb River also may have contributed to the greater concentrations and yields because particulate forms comprised a greater percentage of the organic and ammonia nitrogen concentration than dissolved forms.

\section{Total Phosphorus}

Total phosphorus concentrations and yields (fig. 6, table 7) were greatest in the Little Cobb River. Total phosphorus loads were not computed at the Namekagon River site because 87 percent of the concentrations were less than the method reporting limit. The order of statistical significance for the median total phos- phorus concentrations (beginning with the site with the greatest median concentration) was as follows: Little Cobb River, North Fork Crow River and Shingle Creek and Nine Mile Creek, Namekagon River. There was no consistent difference among yields at the North Fork Crow River, Shingle Creek, and Nine Mile Creek sites.

Median total phosphorus concentrations were greatest in the summer at the Shingle Creek, North Fork Crow River,
Little Cobb River, and Nine Mile Creek sites. The North Fork Crow River site median concentration in the spring was similar to the median concentration in the summer. Greater concentrations in the spring and summer probably were the result of runoff transporting phosphorus from the land surface to the streams. During the fall and winter, transport of phosphorus from the land surface would be restricted because of less precipitation, precipitation falling in the form of snow,
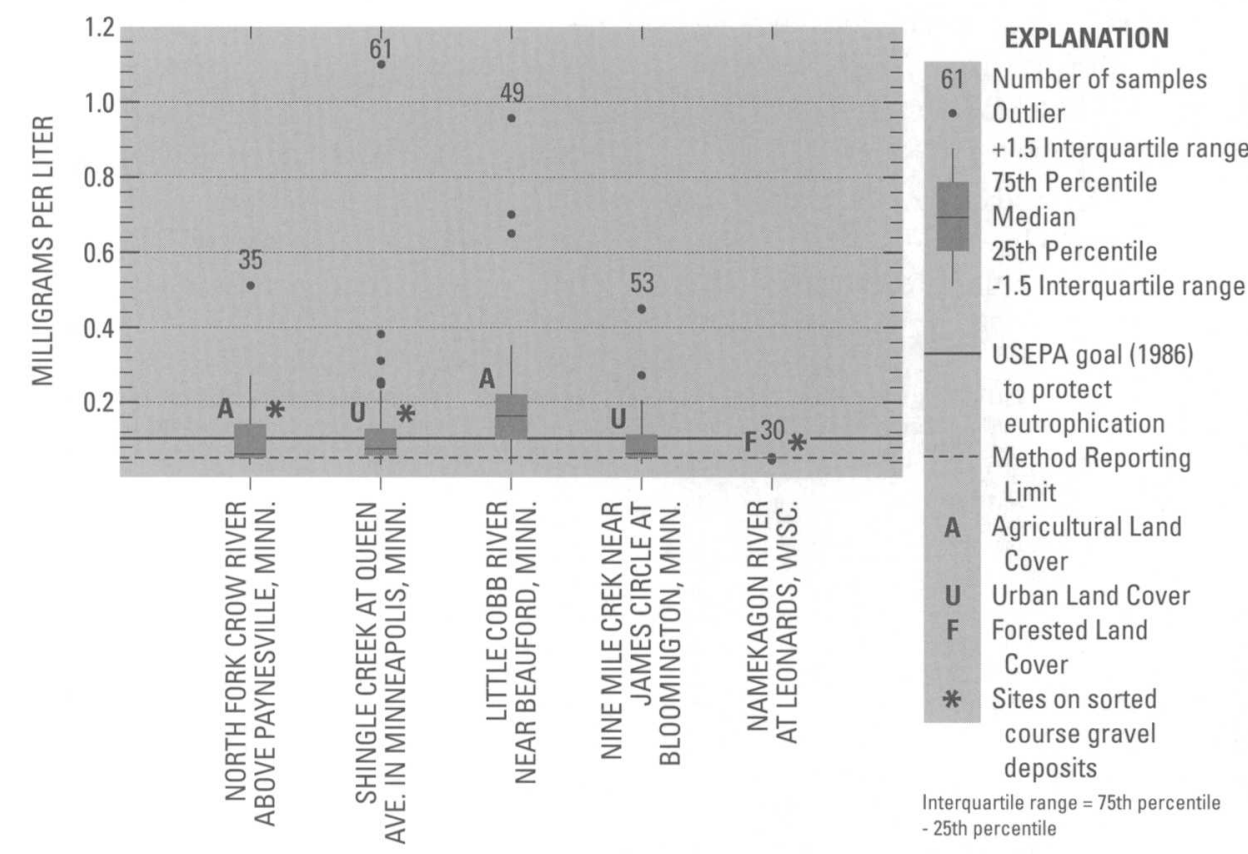

Figure 6. Total phosphorus concentrations at the indicator sites in the Upper Mississippi River Basin Study Unit, April 1996-June 1998.

Table 7. Total phosphorus loads and yields at indicator sites in the Upper Mississippi River Basin Study Unit

[Sites are listed in downstream order; $1 \mathrm{~b} / \mathrm{d}$, pounds per day; $1 \mathrm{~b} / \mathrm{mi}^{2} / \mathrm{d}$, pounds per square mile per day; \%, percent; NC, not computed].

\begin{tabular}{|c|c|c|c|c|c|c|c|c|}
\hline \multirow[b]{2}{*}{$\begin{array}{c}\text { Site } \\
\text { number } \\
\text { (shown } \\
\text { in fig. 1) }\end{array}$} & \multirow[b]{2}{*}{ Site name } & \multirow[b]{2}{*}{$\begin{array}{l}\text { Indicator site } \\
\text { type }\end{array}$} & \multicolumn{3}{|c|}{ Water year 1997} & \multicolumn{3}{|c|}{ Water year 1998} \\
\hline & & & $\begin{array}{l}\text { Mean } \\
\text { daily load } \\
\quad(\mathrm{lb} / \mathrm{d})\end{array}$ & $\begin{array}{l}\text { Mean daily } \\
\text { yield } \\
\left(\mathrm{lb} / \mathrm{mi}^{2} / \mathrm{d}\right)\end{array}$ & $\begin{array}{l}\text { Prediction interval } \\
(95 \%) \text { for mean } \\
\text { daily load }\end{array}$ & $\begin{array}{l}\text { Mean } \\
\text { daily load } \\
\quad(\mathrm{lb} / \mathrm{d})\end{array}$ & $\begin{array}{l}\text { Mean daily } \\
\text { yield } \\
\left(\mathrm{lb} / \mathrm{mi}^{2} / \mathrm{d}\right)\end{array}$ & $\begin{array}{c}\text { Prediction interval } \\
(95 \%) \text { for mean } \\
\text { daily load }\end{array}$ \\
\hline 2 & $\begin{array}{l}\text { North Fork Crow River above } \\
\text { Paynesville, Minn. }\end{array}$ & agriculture & 166 & 0.72 & $35-296$ & 72 & 0.31 & $30-114$ \\
\hline 4 & $\begin{array}{l}\text { Shingle Creek at Queen Ave- } \\
\text { nue in Minneapolis, Minn. }\end{array}$ & urban-residential & 13.5 & 0.48 & $10.0-17.1$ & 7.1 & 0.25 & $5.5-8.7$ \\
\hline 5 & $\begin{array}{l}\text { Little Cobb River near Beau- } \\
\text { ford, Minn. }\end{array}$ & agriculture & 126 & 0.97 & $63-189$ & 109 & 0.84 & $49-170$ \\
\hline 7 & $\begin{array}{l}\text { Nine Mile Creek near James } \\
\text { Circle at Bloomington, Minn. }\end{array}$ & urban-residential & 24 & 0.54 & $16-31$ & $\mathrm{NC}$ & $\mathrm{NC}$ & $\mathrm{NC}$ \\
\hline 9 & $\begin{array}{l}\text { Namekagon River at } \\
\text { Leonards, Wisc. }\end{array}$ & forest & $\mathrm{NC}$ & $\mathrm{NC}$ & $\mathrm{NC}$ & $\mathrm{NC}$ & $\mathrm{NC}$ & $\mathrm{NC}$ \\
\hline
\end{tabular}


and frozen soils. There was little seasonal variation in total phosphorus concentrations at the Namekagon River site. At this site, concentrations were near the method reporting limit.

The total phosphorus goal of 0.1 $\mathrm{mg} / \mathrm{L}$ established by the USEPA to prevent eutrophication (U.S. Environmental Protection Agency, 1986) was exceeded at the North Fork Crow River, Shingle Creek, Little Cobb River, and Nine Mile Creek sites. No exceedances of the goal were measured at the Namekagon River site. Exceedances of the total phosphorus goal were measured most frequently at the Little Cobb River site. At this site, concentrations in 73 percent of the samples analyzed exceeded the goal. In contrast, concentrations in 29 to 39 percent of the samples analyzed from the North Fork Crow River and Shingle and Nine Mile Creek sites exceeded the goal.

\section{Dissolved Orthophosphate}

Median dissolved orthophosphate concentrations and mean annual yields were greatest at the North Fork Crow and Little Cobb River sites. The lowest mean daily yields were at the Shingle Creek site. Median concentrations were significantly greater at the North Fork Crow and Little Cobb River sites compared to the other sites. The order of statistical significance for median concentrations (beginning with the site determined to have the greatest median concentrations) was as follows: Little Cobb River and North Fork Crow River, Nine Mile Creek, Shingle Creek, Namekagon River.

Dissolved orthophosphate composed from near zero to 100 percent of the total phosphorus concentration. At the North Fork Crow River site, dissolved orthophosphate typically composed 68 percent of the total phosphorus concentration in samples with detectable phosphorus concentrations. Dissolved orthophosphate typically composed about 30 percent of the total phosphorus concentration in samples from the other sites, except at the Shingle Creek site where dissolved orthophosphate composed about 17 percent of the total phosphorus concentration.

Median concentrations of dissolved orthophosphate were greatest in the sum- mer at the North Fork Crow, Shingle, and Nine Mile Creek sites (fig. 7). However, the maximum concentrations at the North Fork Crow River site were measured in the spring. Increased concentrations in the spring and summer at these sites may result from runoff of fertilizer from the land surface, where phosphorus typically is applied in the form of phosphate. Dissolved orthophosphate concentrations did not vary appreciably at the Namekagon River site (not shown). At the Little Cobb River site, the median concentrations were slightly greater in winter and fall compared to the other seasons. Lesser median concentrations in the spring and summer at this site may be the result of uptake by biota, because orthophosphate is a form of phosphorus readily assimilated by biota. Lower dissolved ammonia nitrogen concentrations during the spring and summer at this site and increased concentrations of chlorophyll $a$ (see next section) during the growing season indicate that uptake of orthophosphate probably was occurring in the Little Cobb River.

\section{Chlorophyll $a$ and Phytoplankton}

Chlorophyll- $a$ concentrations during the growing season (June through September) were significantly greater at the Little Cobb River site compared to the other indicator sites (fig. 8). The order of statistical significance for median chlorophyll- $a$ concentrations (beginning with the site determined to have the greatest median concentrations was as follows: Little Cobb River, Shingle Creek, Nine Mile Creek, North Fork Crow River, and Namekagon River.

Phytoplankton were identified and enumerated in samples collected from April through September 1996. The median algal abundance (defined as the number of algae in a volume of water) during the growing season ranged from 880 cells per milliliter (cells/mL) at the North Fork Crow River site to 15,000 cells/mL at the Little Cobb River site (table 8).

Diatoms generally dominated the phytoplankton community at the North Fork Crow River site (fig. 9). Diatoms also generally dominated the phytoplankton community in Shingle Creek, Nine
Mile Creek, and the Namekagon River sites. At the Little Cobb River site the phytoplankton community generally changed from primarily diatoms in April and May to blue-green algae during June through September (fig. 9).

\section{Suspended Sediment}

Suspended-sediment concentrations were significantly greater at the Little Cobb River site compared to the other indicator sites (fig. 10). The order of statistical significance for median suspended sediment concentrations (beginning with the site determined to have the greatest median concentration) was as follows: Little Cobb River, North Fork Crow River and Shingle Creek and Nine Mile Creek, Namekagon River. Suspended-sediment yields (table 9) were greatest at the Little Cobb River site, and were least at the Namekagon River site. Yields were similar at the North Fork Crow River and Shingle Creek sites. Yields were not reported at the Nine Mile Creek site because load models developed were not reliable.

Greater median suspended-sediment concentrations and annual yields at the North Fork Crow River, Shingle Creek, Little Cobb River, and Nine Mile Creek sites than at the Namekagon River site probably were caused by greater soil disturbance activities in agricultural and urban areas, such as plowing and construction. Significantly greater median concentrations at the Little Cobb River site compared to the other sites may represent the greater erodibility of soils in this part of the Study Unit. An analysis of soil erosion potentials in the Minnesota River Basin by the University of Minnesota (A. Mallawatantri, University of Minnesota, Department of Soil, Water, and Climate, electronic commun., 2000) showed soils in the Little Cobb River Basin generally have high to extreme water-erosion potential and moderate to high wind-erosion potential. This analysis was done for only the Minnesota River Basin. Soil erosion potentials for the rest of the Study Unit were not available. 

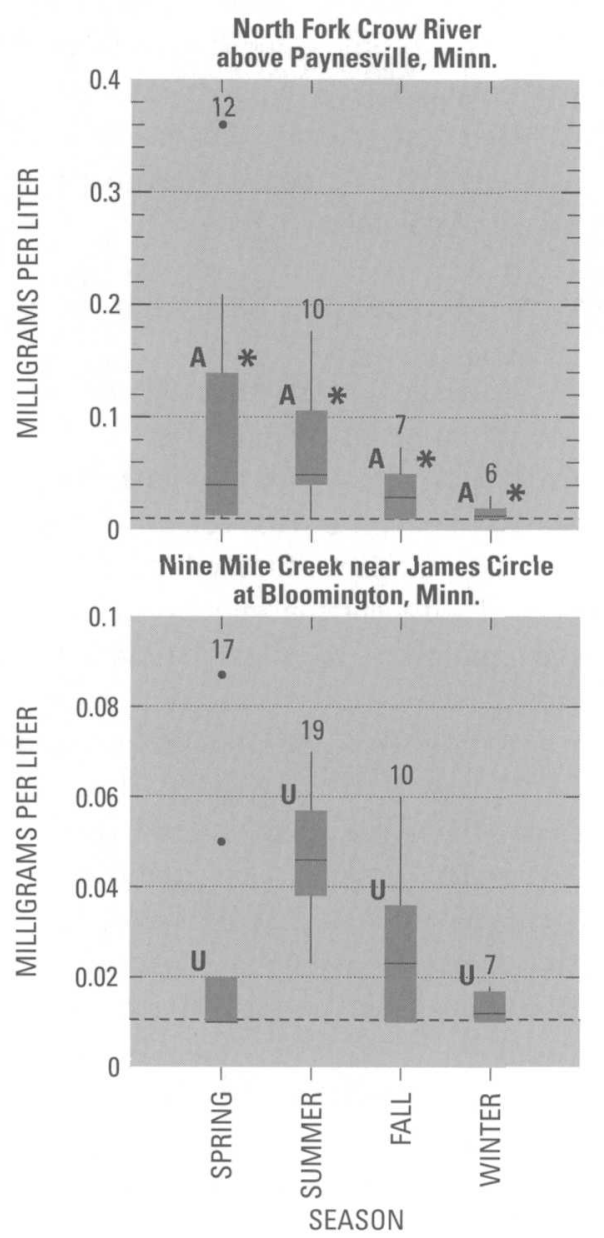
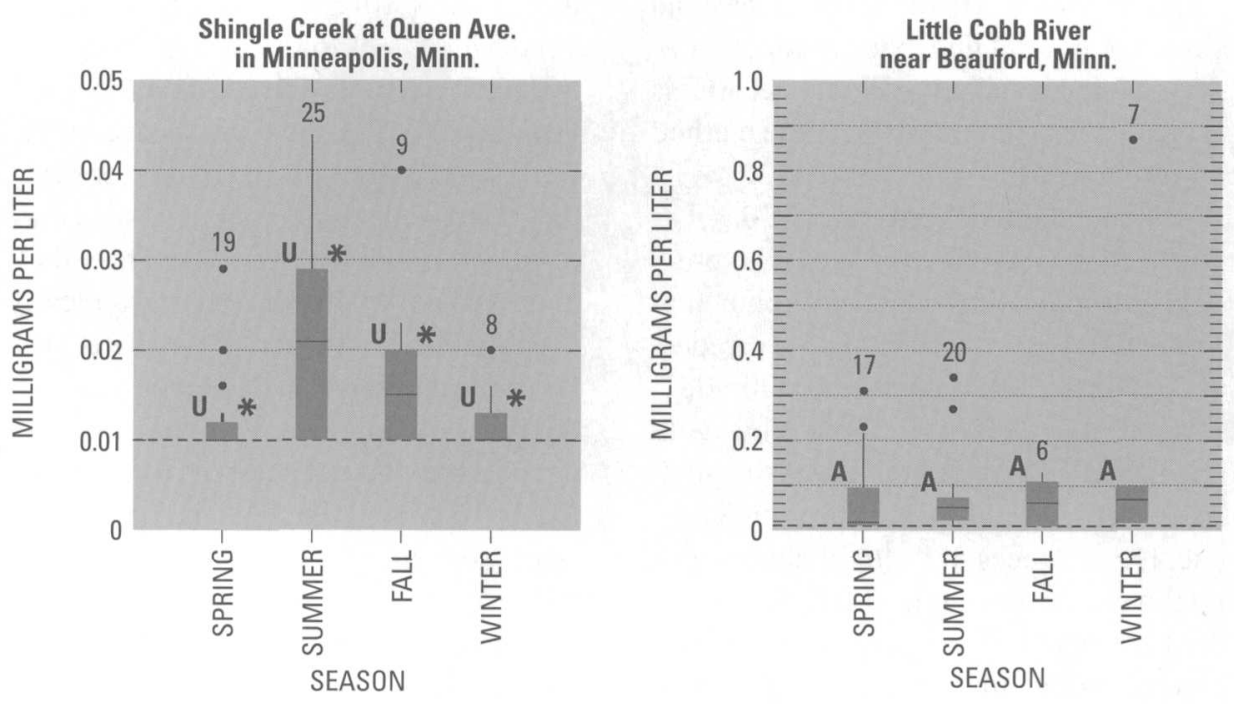

EXPLANATION

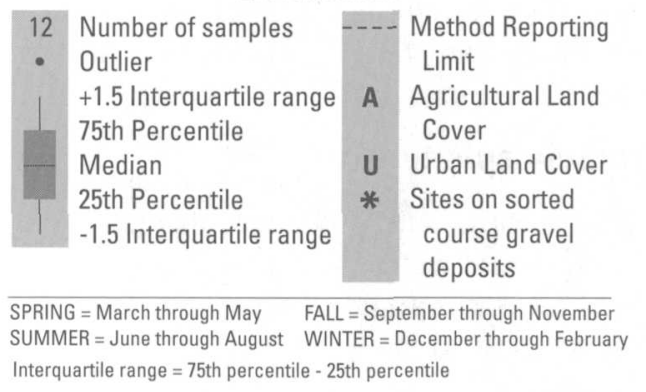

Figure 7. Seasonal variations of dissolved orthophosphate concentrations as phosphorus at the indicator sites in the Upper Mississippi River Basin Study Unit, April 1996-June 1998 (note differences in concentration scales).

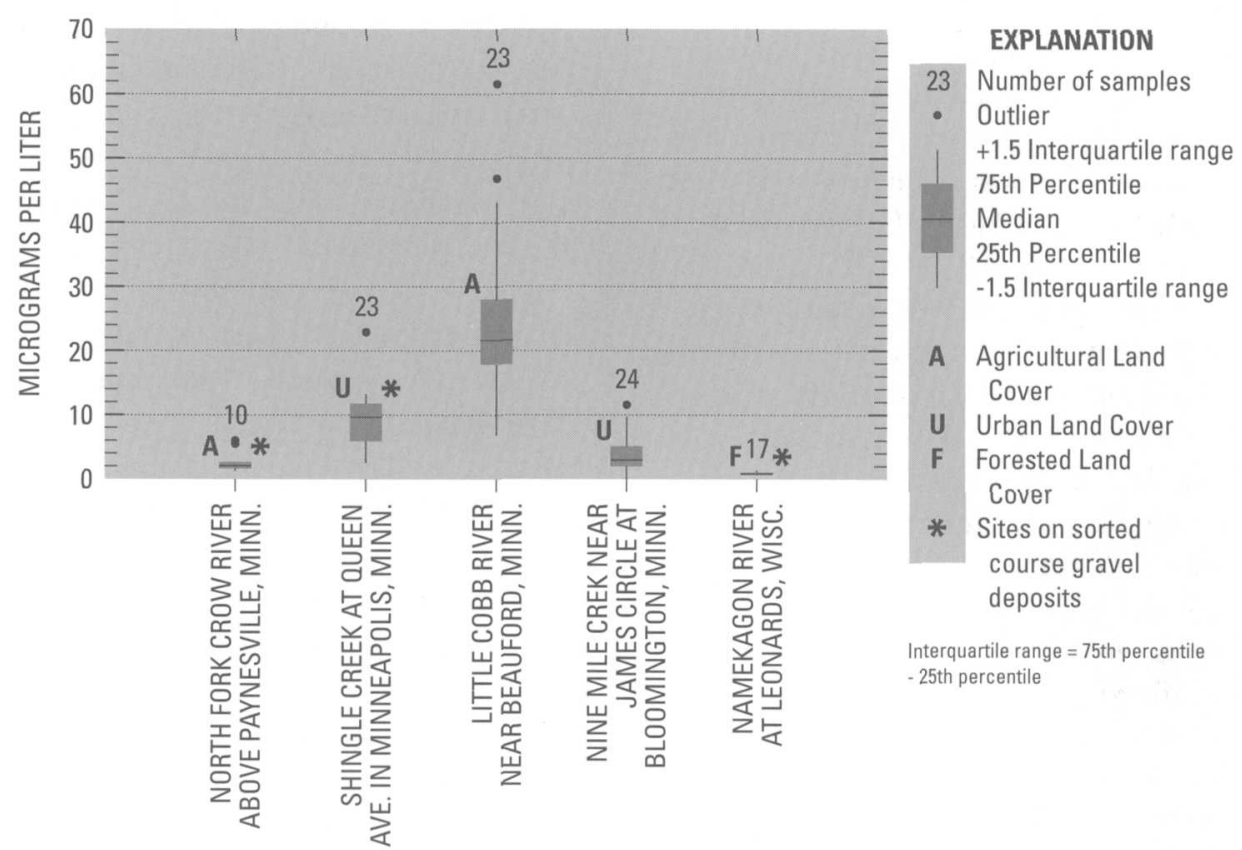

Figure 8. Chlorophyll a concentrations during the growing season at the indicator sites in the Upper Mississippi River Basin Study Unit, April 1996-June 1998.

\section{INTEGRATOR SITES- MISSISSIPPI, MINNESOTA, AND ST. CROIX RIVERS}

Seven integrator sites were sampled on the Mississippi, Minnesota, and St. Croix Rivers (fig.1, table 1). Four sites were sampled on the Mississippi River near the cities of Royalton, Anoka, Hastings, and Red Wing, Minnesota. The site near the city of Royalton (Royalton site), Minnesota (fig. 1) represents the quality of the Mississippi River in an area which is mostly forested. The sites near Anoka (Anoka site), Hastings (Hastings site), and Red Wing (Red Wing site) (fig. 1) represents mixed land cover in the Mississippi River Basin within and downstream of the TCMA. The Anoka site is located upstream from the Minnesota River and near the primary public-water 
Table 8. Median algal abundance at indicator sites in the Upper Mississippi River Basin Study Unit, June-September 1996.

[Sites are listed in downstream order.]

\begin{tabular}{ccllr}
\hline $\begin{array}{c}\text { Site number } \\
\text { (shown in fig. 1) }\end{array}$ & $\begin{array}{c}\text { U.S. Geological } \\
\text { Survey site } \\
\text { identifier }\end{array}$ & Indicator site type & & Site name \\
\hline 2 & 05276005 & agriculture & North Fork Crow River above Paynesville, Minn. & $\begin{array}{c}\text { Median algal abundance } \\
\text { (in number of cells per mil- } \\
\text { liliter) }\end{array}$ \\
4 & 05288705 & urban-residential & Shingle Creek at Queen Avenue in Minneapolis, Minn. & \\
5 & 05320270 & agriculture & Little Cobb River near Beauford, Minn. & 7,000 \\
7 & 05330902 & urban-residential & Nine Mile Creek near James Circle at Bloomington, Minn. \\
9 & 05331833 & forest & Namekagon River at Leonards, Wisc. & 4,000 \\
4,000
\end{tabular}

supply intakes for Minneapolis and St. Paul. The Hastings site integrates the influences of the Minnesota River and most of the wastewater discharges from the TCMA. The Red Wing site integrates the influence of the St. Croix River on the Mississippi River and represents the Mississippi River immediately upstream from Lake Pepin, which is the outlet of the Study Unit. Two sites were sampled on the St. Croix River near Danbury (Danbury site) and St. Croix Falls (St. Croix Falls site), Wisconsin (table 1). The Danbury site represents the St. Croix River in an area that is primarily forest and wetlands, and the St. Croix Falls site represents influences of forest and agricultural land cover.

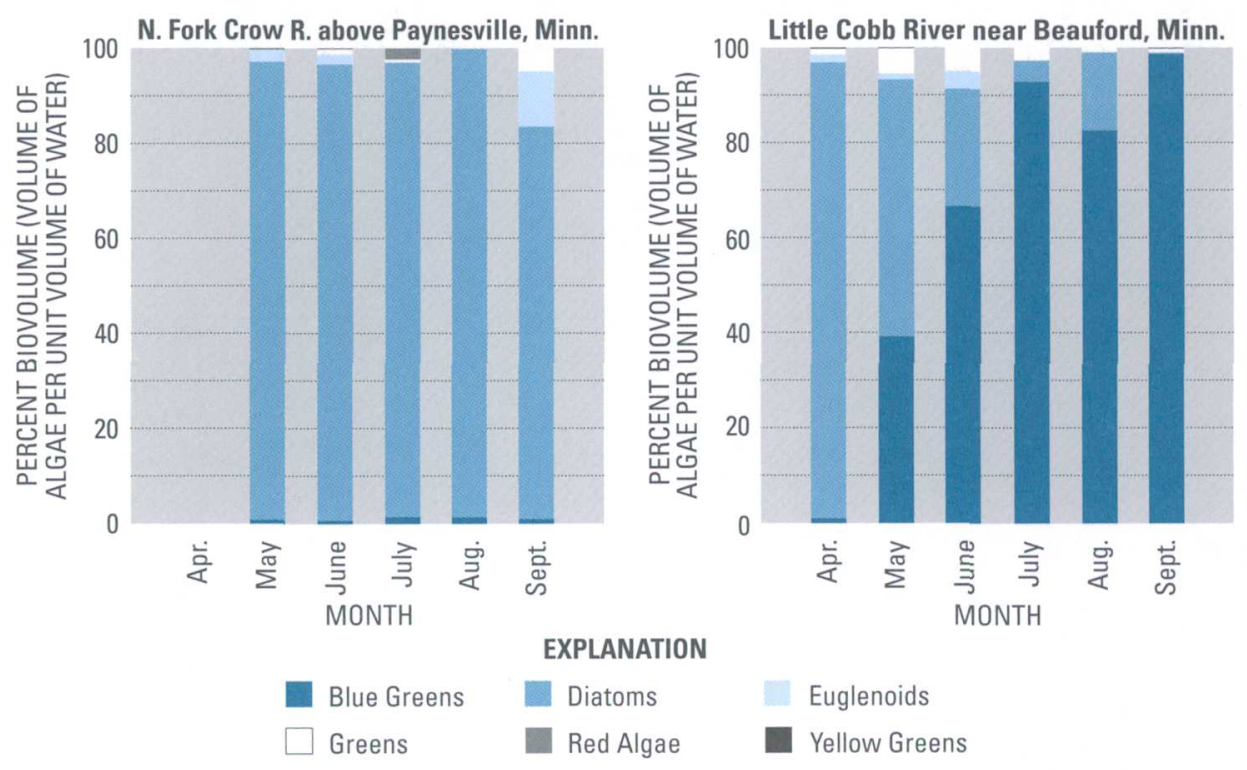

Figure 9. Seasonal variations in the phytoplankton community, by algal group, in the North Fork Crow River above Paynesville, Minnesota, and the Little Cobb River near Beauford, Minnesota, in the Upper Mississippi River Basin Study Unit, 1996. site $(1.6 \mathrm{mg} / \mathrm{L})$ also was greater than the maximum concentration at the Danbury site $(0.8 \mathrm{mg} / \mathrm{L})$.

Total nitrogen loads and yields in water years 1997 and 1998 are shown in table 10 . The most substantial increase in mean daily loads at the Hastings site primarily was due to inputs from the Minnesota River. In contrast to the concentration data, mean daily total nitrogen loads at the Red Wing site are greater than at the Hastings site, which is a result of nitrogen contributions from the St. Croix, Cannon, and Vermillion Rivers (Kroening and Andrews, 1997). Mean daily total nitrogen loads in the St. Croix River increased by about a factor of 6 from the Danbury to St. Croix Falls. sites.

The composition of the total nitrogen load varied among the sites. At the Royalton, Danbury, and St. Croix Falls sites, dissolved nitrite plus nitrate nitrogen composed about 20 to 30 percent of the total nitrogen load. At Anoka site, about 40 percent of the total nitrogen load was dissolved nitrite plus nitrate nitrogen. At the Hastings and the Red Wing sites, dissolved nitrite plus nitrate nitrogen composed about 70 percent of the total nitrogen load. At the Jordan site, greater than 80 percent of the total nitrogen load was dissolved nitrite plus nitrate nitrogen. These differences in the composition of the nitrogen load probably reflect differences in the predominant land covers integrated by each of these sites. Sites on the Mississippi and St. Croix Rivers with the least percentage of dissolved nitrite plus nitrate nitrogen integrated areas with a greater percentage of forest and wetland cover (figs. 1 and 2). The Jordan, Hastings, and the Red Wing sites integrated areas with the greatest percentage of agricultural land cover. 


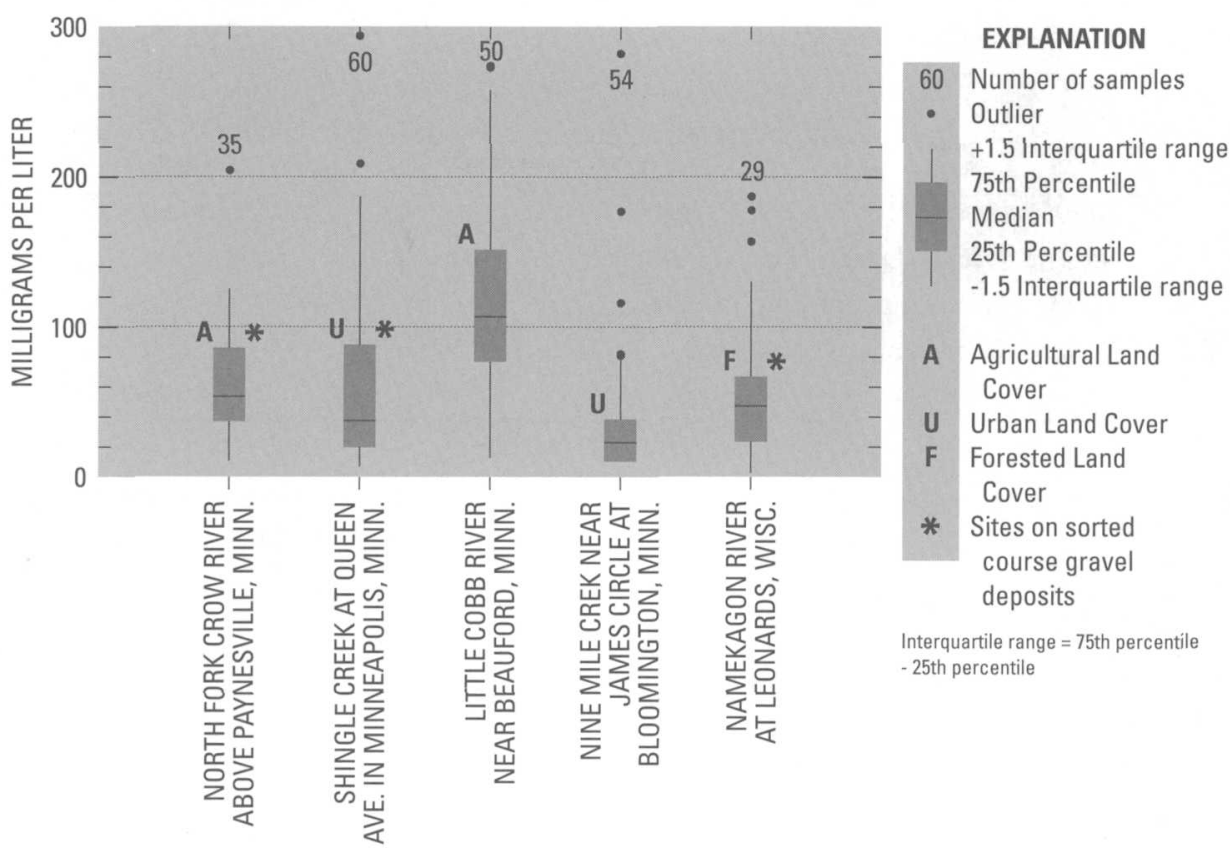

Figure 10. Suspended-sediment concentrations at the indicator sites in the Upper Mississippi River Basin Study Unit, April 1996-June 1998.

\section{Dissolved nitrite nitrogen}

Dissolved nitrite nitrogen concentrations ranged from less than the method reporting limit $(0.01 \mathrm{mg} / \mathrm{L})$ to $0.13 \mathrm{mg} / \mathrm{L}$. Dissolved nitrite nitrogen was detected in 30-38 percent of the samples analyzed from the Royalton, Danbury, and St. Croix Falls sites. Dissolved nitrite nitrogen was detected in 95 to 100 percent of the samples analyzed from the Jordan, Hastings, and Red Wing sites. The greatest median concentrations also were in samples from the Jordan site $(0.03 \mathrm{mg} / \mathrm{L})$, the Hastings site $(0.04 \mathrm{mg} / \mathrm{L})$, and the Red Wing site $(0.03 \mathrm{mg} / \mathrm{L})$.

\section{Dissolved nitrite plus nitrate nitrogen}

Dissolved nitrite plus nitrate nitrogen concentrations ranged from less than the method reporting limit (MRL) (0.05 $\mathrm{mg} / \mathrm{L}$ ) to $13 \mathrm{mg} / \mathrm{L}$ (fig. 12). Concentrations had a spatial distribution similar to total nitrogen. The greatest median concentrations were at the Jordan site (4.0 $\mathrm{mg} / \mathrm{L})$, Hastings site $(1.9 \mathrm{mg} / \mathrm{L})$, and the
Red Wing site $(1.7 \mathrm{mg} / \mathrm{L})$. The maximum contaminant level (MCL) of $10 \mathrm{mg} / \mathrm{L}$ as nitrogen set by the USEPA (1986) for drinking water was exceeded in 11 percent of the samples analyzed from the Jordan site. Exceedances of the MCL were not measured at the other sites. In the Mississippi River, median dissolved nitrite plus nitrate nitrogen concentrations were significantly greater at the Hastings and Red Wing sites than the Royalton site. There was no significant difference between median concentrations at the Hastings and Red Wing sites. In the St. Croix River, median concentrations were significantly greater at the St. Croix Falls site $(0.2 \mathrm{mg} / \mathrm{L})$ than the Danbury site $(0.1 \mathrm{mg} / \mathrm{L})$. Mean daily loads and yields (table 11) indicated a pattern similar to concentrations. However, loads increased in the Mississippi River between the Hastings and Red Wing sites due to inputs from the St. Croix River and other tributaries.

Seasonal variations in dissolved nitrite plus nitrate nitrogen concentrations also differed among the sites (fig. 13). At the sites upstream of the TCMA, Royalton, Danbury, and St. Croix Falls, the greatest concentrations occurred in the winter and spring. Dissolved nitrite plus nitrate nitrogen concentrations at the Jordan, Hastings, and Red Wing sites were greatest in the spring and summer. Greater concentrations during spring and summer indicated dissolved nitrite plus nitrate nitrogen concentrations at these

Table 9. Suspended-sediment loads and yields at indicator sites in the Upper Mississippi River Basin Study Unit [Sites are listed in downstream order; tons/d, tons per day; $1 \mathrm{~b} / \mathrm{mi}^{2} / \mathrm{d}$, pounds per square mile per day; $\mathrm{NC}$, not computed].

\begin{tabular}{|c|c|c|c|c|c|c|c|c|}
\hline \multirow[b]{2}{*}{$\begin{array}{l}\text { Site num- } \\
\text { ber (shown } \\
\text { in fig. 1) }\end{array}$} & \multirow[b]{2}{*}{ Site name } & \multirow[b]{2}{*}{ Indicator site type } & \multicolumn{3}{|c|}{ Water year 1997} & \multicolumn{3}{|c|}{ Water year 1998} \\
\hline & & & $\begin{array}{c}\text { Mean daily } \\
\text { load } \\
\text { (tons/d) }\end{array}$ & $\begin{array}{c}\text { Mean daily } \\
\text { yield } \\
\left(\mathrm{lb} / \mathrm{mi}^{2} / \mathrm{d}\right)\end{array}$ & $\begin{array}{c}\text { Prediction } \\
\text { interval (95\%) } \\
\text { for mean daily } \\
\text { load }\end{array}$ & $\begin{array}{c}\text { Mean daily } \\
\text { load } \\
\text { (tons/d) }\end{array}$ & $\begin{array}{c}\text { Mean daily } \\
\text { yield } \\
\left(\mathrm{lb} / \mathrm{mi}^{2} / \mathrm{d}\right)\end{array}$ & $\begin{array}{c}\text { Prediction } \\
\text { interval }(95 \%) \\
\text { for mean daily } \\
\text { load }\end{array}$ \\
\hline 2 & $\begin{array}{l}\text { North Fork Crow River above } \\
\text { Paynesville, Minn. }\end{array}$ & agriculture & 17.5 & 0.08 & $10.6-24.4$ & 13.3 & 0.06 & $9.7-17.0$ \\
\hline 4 & $\begin{array}{l}\text { Shingle Creek at Queen Avenue } \\
\text { in Minneapolis, Minn. }\end{array}$ & $\begin{array}{l}\text { urban-residen- } \\
\text { tial }\end{array}$ & 2.7 & 0.10 & $1.8-3.6$ & 1.9 & 0.07 & $1.3-2.4$ \\
\hline 5 & $\begin{array}{l}\text { Little Cobb River near Beauford, } \\
\text { Minn. }\end{array}$ & agriculture & 42.6 & 0.33 & $28.0-57.3$ & 36.1 & 0.28 & $22.7-49.5$ \\
\hline 7 & $\begin{array}{l}\text { Nine Mile Creek near James Cir- } \\
\text { cle at Bloomington, Minn. }\end{array}$ & $\begin{array}{l}\text { urban-residen- } \\
\text { tial }\end{array}$ & $\mathrm{NC}$ & $\mathrm{NC}$ & $\mathrm{NC}$ & $\mathrm{NC}$ & $\mathrm{NC}$ & $\mathrm{NC}$ \\
\hline 9 & $\begin{array}{l}\text { Namekagon River at Leonards, } \\
\text { Wisc. }\end{array}$ & forest & 1.9 & 0.02 & $1.4-2.4$ & 1.4 & 0.01 & $1.1-1.8$ \\
\hline
\end{tabular}




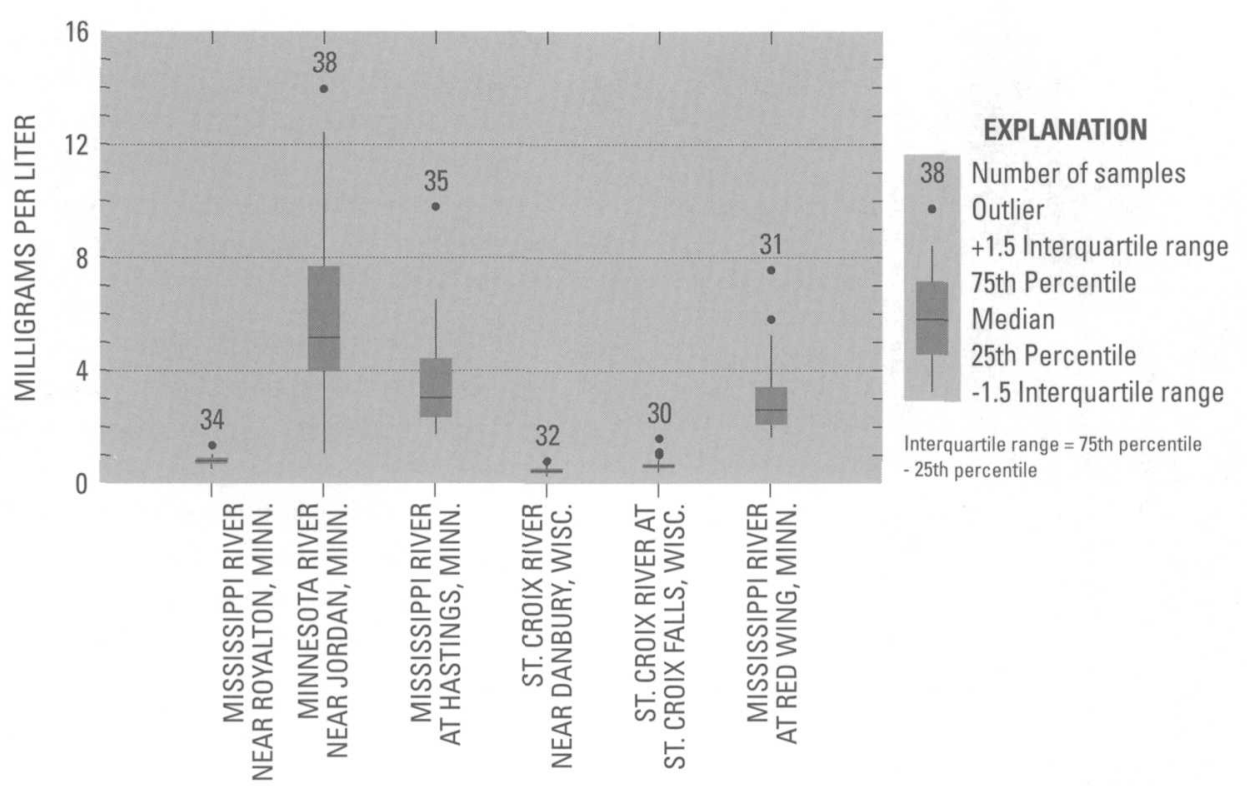

Figure 11. Total nitrogen concentrations as nitrogen at the Mississippi, Minnesota, and St. Croix River sites in the Upper Mississippi River Basin Study Unit, April 1996-June 1998.

sites were influenced by runoff from agricultural areas.

\section{Dissolved ammonia nitrogen}

Dissolved ammonia nitrogen concentrations ranged from less than the MRL $(0.02 \mathrm{mg} / \mathrm{L})$ to $0.5 \mathrm{mg} / \mathrm{L}$. Dissolved ammonia nitrogen concentrations near the method reporting limit $(0.02 \mathrm{mg} / \mathrm{L})$ may be the result of the introduction of contamination during the sampling or analysis procedures. The median concentration was greatest at the Hastings site. Concentrations also were the most variable at this site. The median dissolved ammonia nitrogen concentration at the Hastings site $(0.08 \mathrm{mg} / \mathrm{L})$ determined as part of this study was about one-half of the median concentration reported by Kroening and Andrews (1997). Lesser concentrations determined as part of this study are consistent with results from temporal trend analyses (Kroening and Andrews, 1997), in which decreases in ammonia nitrogen concentrations were attributed to reduced concentrations in municipal wastewater discharged in the TCMA.

Dissolved ammonia nitrogen concentrations generally were greatest during the winter and spring (fig. 14). Greater concentrations during the winter may be the result of reduced uptake by biota or reduced nitrification caused by cooler water temperatures. Municipal wastewater effluent discharged to these rivers within the TCMA also is permitted to contain greater concentrations of ammonia during the winter months. Other potential sources of ammonia to these streams include leaking sewerage and septic systems and inputs from livestock feedlots. Dissolved ammonia nitrogen from these sources may be more concentrated in these streams during the winter as a result of reduced streamflow.

\section{Organic plus ammonia nitrogen}

Total organic plus ammonia nitrogen concentrations ranged from near MRL (0.10-0.20 mg/L) to $2.1 \mathrm{mg} / \mathrm{L}$. Concentrations generally had similar spatial and temporal distribution to those for total nitrogen and dissolved nitrite plus nitrate nitrogen. Total organic plus ammonia

Table 10. Total nitrogen loads and yields at the Mississippi, Minnesota, and St. Croix River sites in the Upper Mississippi River Basin Study Unit

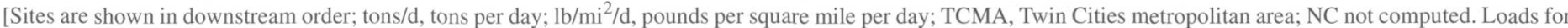
wastewater discharges from the TCMA were provided by C. Larson, Twin Cities Metropolitan Council.]

\begin{tabular}{|c|c|c|c|c|c|c|}
\hline \multirow[b]{2}{*}{$\begin{array}{c}\text { Site num- } \\
\text { ber } \\
\text { (shownin } \\
\text { fig. 1) }\end{array}$} & \multirow[b]{2}{*}{$\begin{array}{l}\text { USGS site } \\
\text { identifier }\end{array}$} & \multirow[b]{2}{*}{ Site name } & \multicolumn{4}{|c|}{ Water year 1998} \\
\hline & & & $\begin{array}{c}\text { Mean daily } \\
\text { load } \\
\text { (tons/d) }\end{array}$ & $\begin{array}{l}\text { Mean daily } \\
\text { yield } \\
\left(\mathrm{lb} / \mathrm{mi}^{2} / \mathrm{d}\right)\end{array}$ & $\begin{array}{c}\text { Mean daily } \\
\text { load } \\
\text { (tons/d) }\end{array}$ & $\begin{array}{c}\text { Mean daily } \\
\text { yield } \\
\left(\mathrm{lb} / \mathrm{mi}^{2} / \mathrm{d}\right)\end{array}$ \\
\hline 1 & 05267000 & Mississippi River near Royalton, Minn. & 19.4 & 3.3 & 12.1 & 2.1 \\
\hline 3 & 05288500 & Mississippi River near Anoka, Minn. & 51.0 & 5.3 & 36.0 & 3.7 \\
\hline \multirow[t]{2}{*}{6} & 05330000 & Minnesota River near Jordan, Minn. & 238 & 29.4 & 149 & 18.4 \\
\hline & & $\begin{array}{l}\text { Wastewater discharges from the TCMA to the Mississippi and Minne- } \\
\text { sota Rivers }\end{array}$ & 19.8 & $\mathrm{NC}$ & 19.8 & $\mathrm{NC}$ \\
\hline 8 & 05331580 & Mississippi River below Lock and Dam 2 at Hastings, Minn. & 259 & 14.0 & 156 & 8.4 \\
\hline 10 & 05333500 & St. Croix River near Danbury, Wisc. & 2.0 & 2.7 & 1.4 & 1.9 \\
\hline \multirow[t]{2}{*}{11} & 05340500 & St. Croix River at St. Croix Falls, Wisc. & 12.0 & 3.8 & 7.3 & 2.3 \\
\hline & & $\begin{array}{l}\text { Wastewater discharges from the TCMA to the Mississippi and St. } \\
\text { Croix Rivers at Vermillion }\end{array}$ & 1.2 & $\mathrm{NC}$ & 1.2 & $\mathrm{NC}$ \\
\hline 12 & 05355250 & Mississippi River at Red Wing, Minnesota & 272 & 11.6 & 179 & 7.6 \\
\hline
\end{tabular}




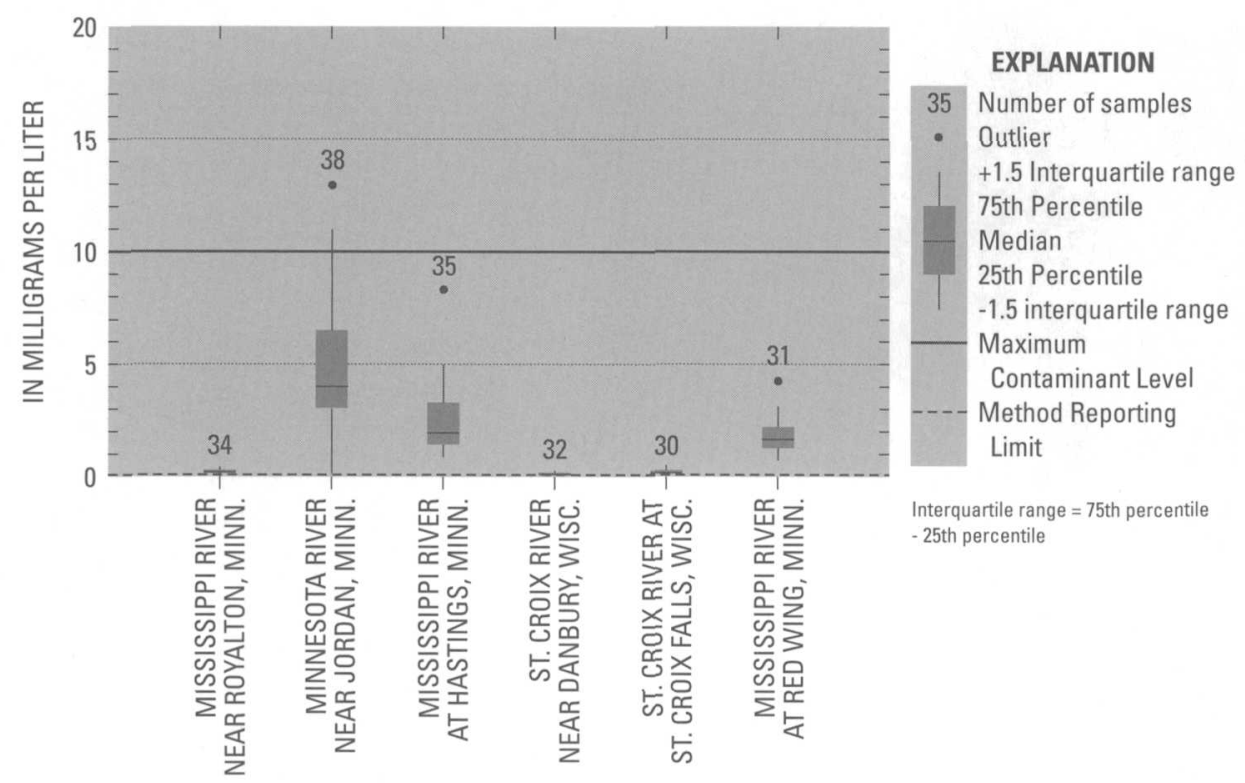

Figure 12. Dissolved nitrite plus nitrate nitrogen concentrations as nitrogen at the Mississippi, Minnesota, and St. Croix River sites in the Upper Mississippi River Basin Study Unit, April 1996-June 1998.

nitrogen concentrations were significantly greater at the Jordan, Hastings, and Red Wing sites compared to other sites. Concentrations at the Hastings site were significantly greater than concentrations at the Red Wing site, and the Red Wing site were significantly greater than the Royalton site. In the St. Croix River, total organic plus ammonia nitrogen concentrations were significantly greater at the Dan- bury site. Mean daily loads and yields (table 12) generally followed a pattern similar to concentrations. However, loads increased in the Mississippi River between the Hastings and Red Wing sites due to inputs from the St. Croix River and other tributaries.

Total organic plus ammonia nitrogen concentrations generally were greatest in the spring and summer and least in the winter and fall. This corresponds to the period when streamflow generally is greatest in the Study Unit, which indicates that runoff from the land surface contributed much of the organic plus ammonia nitrogen to these streams.

Dissolved organic plus ammonia nitrogen generally comprised 55 to 66 percent of the total organic plus ammonia nitrogen concentration at the Jordan, Hastings, and Red Wing sites. In contrast, dissolved organic plus ammonia nitrogen generally comprised 72 to 83 percent of the total organic plus ammonia nitrogen concentration at the Royalton site and the St. Croix River.

Table 11. Dissolved nitrite plus nitrate nitrogen loads and yields at the Mississippi, Minnesota, and St. Croix River sites in the Upper Mississippi River Basin Study Unit

[Sites are listed in downstream order; tons/d, tons per day; lb/mi ${ }^{2} / \mathrm{d}$, pounds per square mile per day; \%, percent; TCMA, Twin Cities metropolitan area; NC, not computed. Loads for wastewater discharges from the TCMA were provided by C. Larson, Twin Cities Metropolitan Council]

\begin{tabular}{|c|c|c|c|c|c|c|c|c|}
\hline \multirow[b]{2}{*}{$\begin{array}{l}\text { Site } \\
\text { number } \\
\text { (shown in } \\
\text { fig. 1) }\end{array}$} & \multirow[b]{2}{*}{$\begin{array}{l}\text { U.S. Geologi- } \\
\text { cal Survey } \\
\text { site identifier }\end{array}$} & \multirow[b]{2}{*}{ Site name } & \multicolumn{3}{|c|}{ Water year 1997} & \multicolumn{3}{|c|}{ Water year 1998} \\
\hline & & & $\begin{array}{l}\text { Mean } \\
\text { daily load } \\
\text { (tons/d) }\end{array}$ & $\begin{array}{l}\text { Mean } \\
\text { daily yield } \\
\left(\mathrm{lb} / \mathrm{mi}^{2} / \mathrm{d}\right)\end{array}$ & $\begin{array}{c}\text { Prediction } \\
\text { interval } \\
(95 \%) \text { for } \\
\text { mean daily } \\
\text { load }\end{array}$ & $\begin{array}{l}\text { Mean } \\
\text { daily load } \\
\text { (tons/d) }\end{array}$ & $\begin{array}{l}\text { Mean daily } \\
\text { yield } \\
\left(\mathrm{lb} / \mathrm{mi}^{2} / \mathrm{d}\right)\end{array}$ & $\begin{array}{l}\text { Prediction } \\
\text { interval } \\
(95 \%) \text { for } \\
\text { mean daily } \\
\text { load }\end{array}$ \\
\hline 1 & 05267000 & Mississippi River near Royalton, Minn. & 4.4 & 0.76 & $3.5-4.8$ & 2.9 & 0.5 & $2.4-3.3$ \\
\hline 3 & 05288500 & Mississippi River near Anoka, Minn. & 21 & 2.2 & $15-27$ & 16 & 1.7 & $12-21$ \\
\hline \multirow[t]{2}{*}{6} & \multirow[t]{2}{*}{05330000} & Minnesota River near Jordan, Minn. & 199 & 25 & $101-297$ & 128 & 16 & $69-186$ \\
\hline & & $\begin{array}{l}\text { Wastewater discharges from the TCMA } \\
\text { to the Mississippi and Minnesota Riv- } \\
\text { ers }\end{array}$ & 14.1 & NC & $\mathrm{NC}$ & 14.9 & NC & $\mathrm{NC}$ \\
\hline 8 & 05331580 & $\begin{array}{l}\text { Mississippi River below Lock and Dam } 2 \\
\text { at Hastings, Minn. }\end{array}$ & 178 & 9.6 & $126-231$ & 107 & 5.8 & $85-130$ \\
\hline 10 & 05333500 & St. Croix River near Danbury, Wisc. & 0.5 & 0.7 & $0.5-0.6$ & 0.4 & 0.5 & $0.3-0.4$ \\
\hline \multirow[t]{2}{*}{11} & \multirow[t]{2}{*}{05340500} & St. Croix River at St. Croix Falls, Wisc. & 3.0 & 1.0 & $1.0-4.0$ & 2.0 & 2.7 & $0.9-3.0$ \\
\hline & & $\begin{array}{l}\text { Wastewater discharges from the TCMA } \\
\text { to the Mississippi and St. Croix Rivers } \\
\text { at Vermillion }\end{array}$ & 1.1 & $\mathrm{NC}$ & $\mathrm{NC}$ & 1.1 & $\mathrm{NC}$ & NC \\
\hline 12 & 05355250 & $\begin{array}{l}\text { Mississippi River at Red Wing, Minne- } \\
\text { sota }\end{array}$ & 190 & 8.1 & $142-238$ & 122 & 5.2 & $99-146$ \\
\hline
\end{tabular}



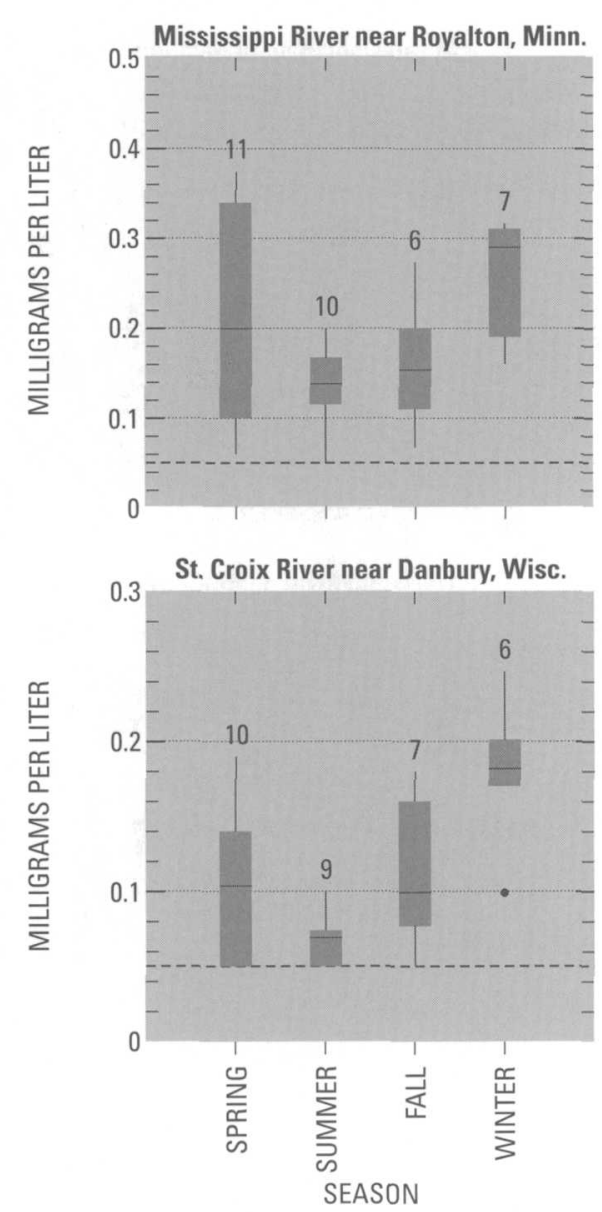

Figure 13. Seasonal variations in dissolved nitrite plus nitrate nitrogen concentrations as nitrogen at the Mississippi, Minnesota, and St. Croix River sites in the Upper Mississippi River Basin Study Unit, April 1996-June 1998 (note differences in concentration scales).

\section{Total Phosphorus}

Total phosphorus concentrations ranged from less than the MRL $(0.05$ $\mathrm{mg} / \mathrm{L}$ ) to $0.51 \mathrm{mg} / \mathrm{L}$ (fig. 15 ). Concentrations had the same general pattern to those found for total nitrogen, dissolved nitrite plus nitrate nitrogen, and total organic plus ammonia nitrogen concentrations, with concentrations at the Jordan and Hastings sites being significantly greater than those from the other sites.

Total phosphorus concentrations at the Hastings site were the result of contri-
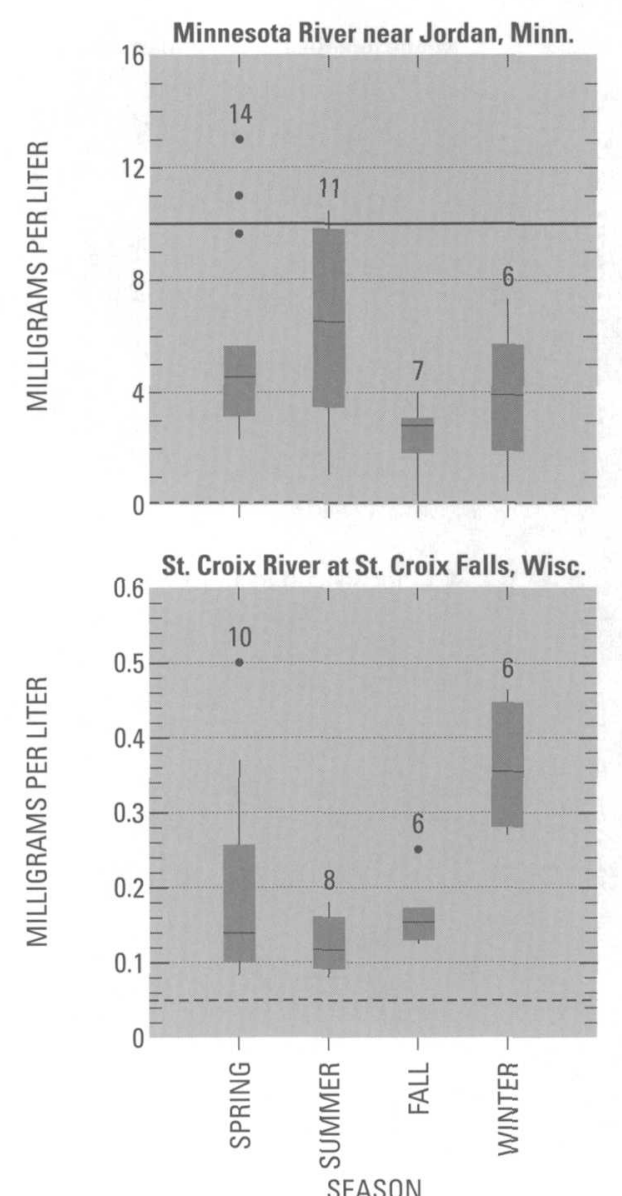

EXPLANATION

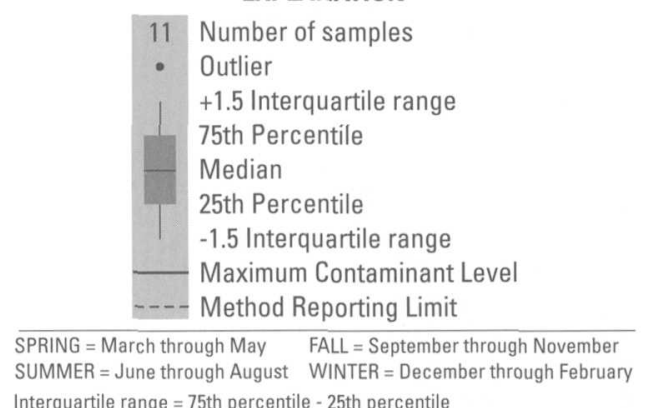

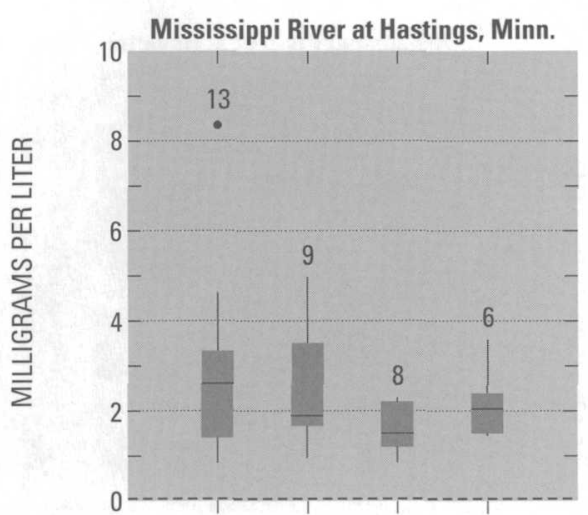

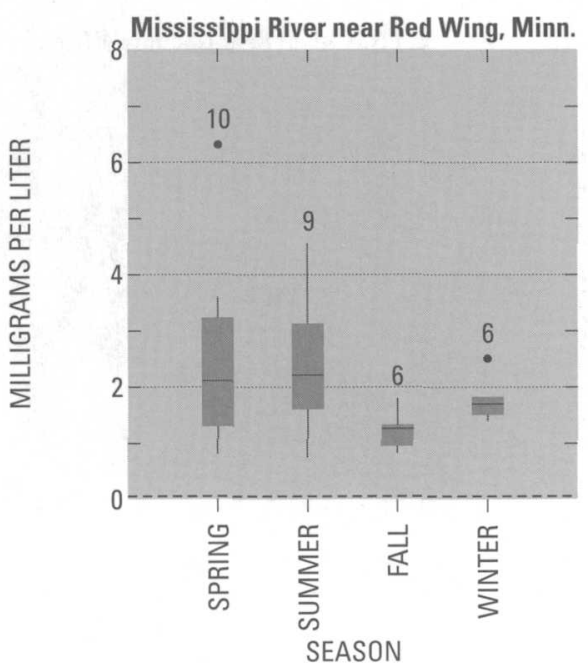



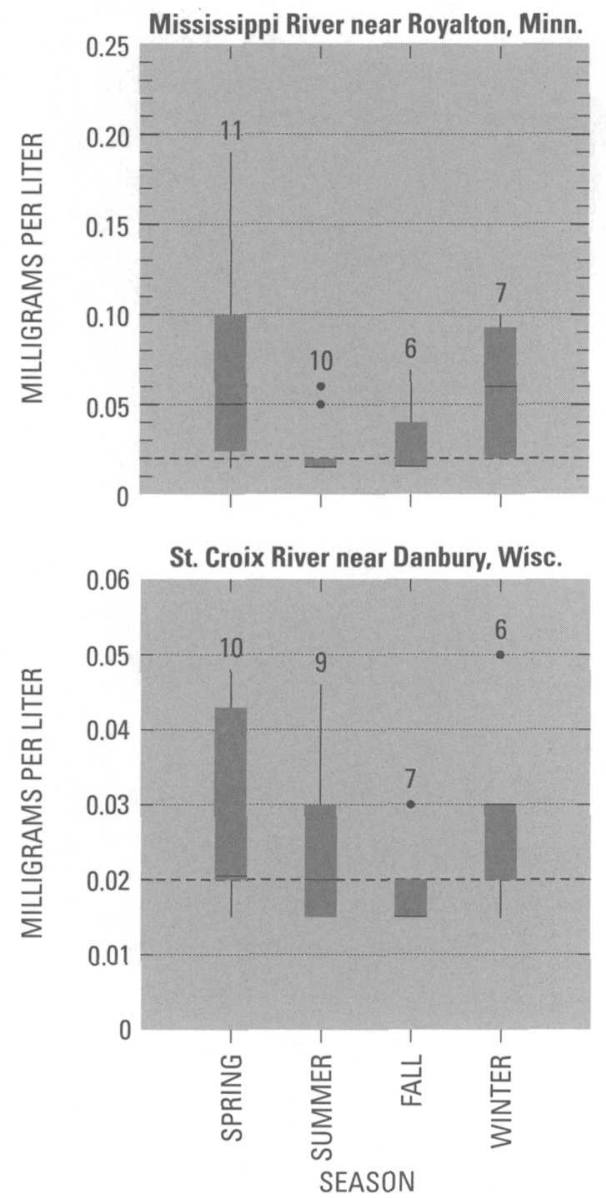

SEASON
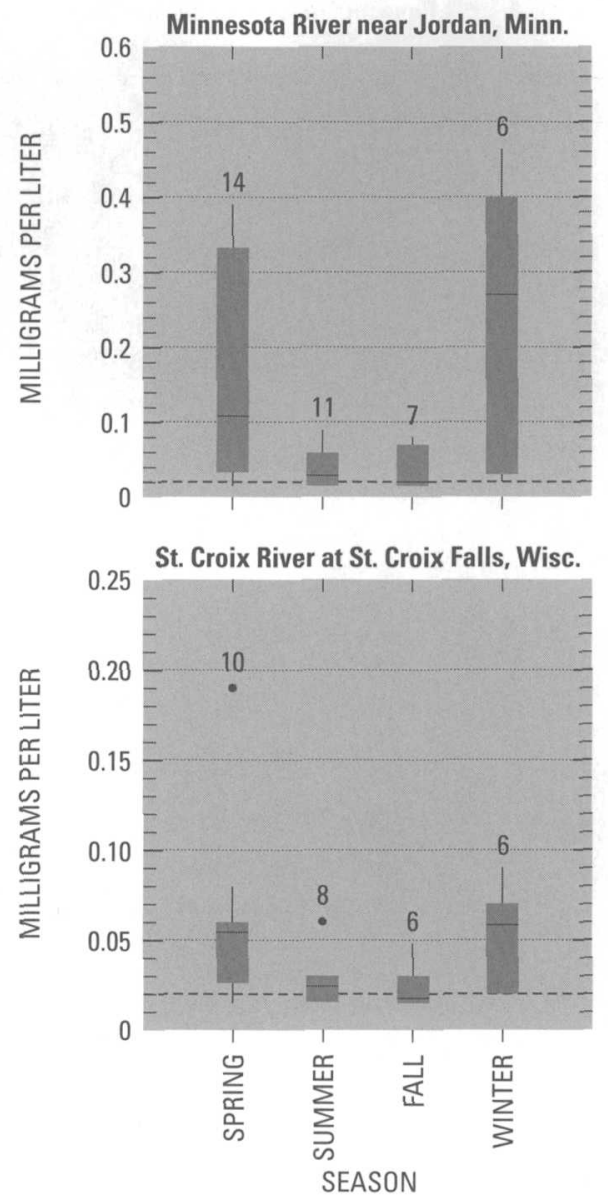

\section{EXPLANATION}

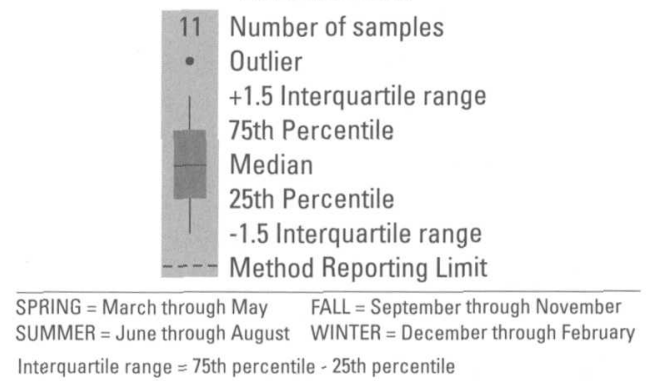

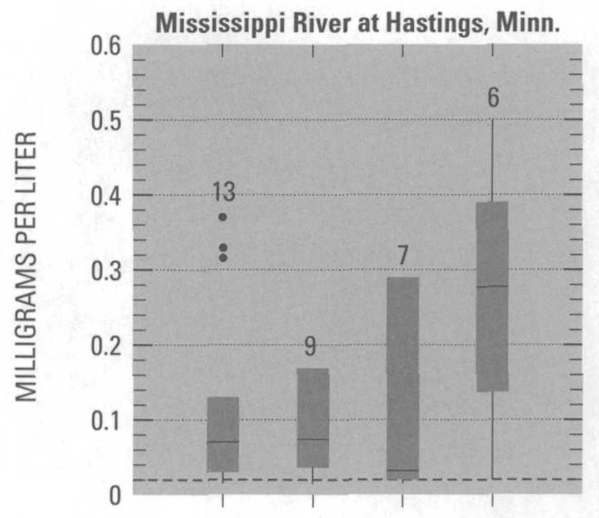

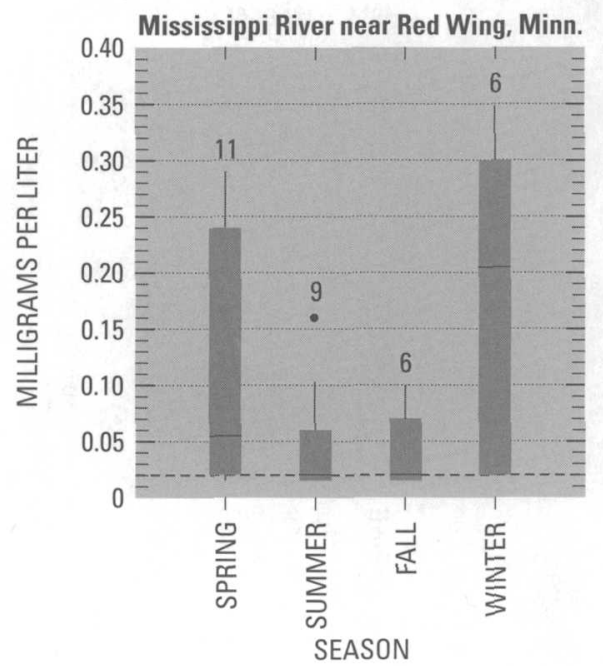

Figure 14. Seasonal variations in dissolved ammonia nitrogen concentrations as nitrogen at the Mississippi, Minnesota, and St. Croix River sites in the Upper Mississippi River Basin Study Unit, April 1996-June 1998 (note differences in concentration scales).

to prevent eutrophication (fig. 15). The goal was exceeded most frequently at the Jordan, Hastings, and Red Wing sites. At these sites, concentrations in 86 to 91 percent of the samples exceeded the goal. At the St. Croix Falls site, concentrations in 3 percent of the samples exceeded the goal. Only one exceedance of the goal was measured at the Royalton site, and one at the Danbury site. Phosphorus loads and yield are shown in table 13 .

There was little seasonal variation in total phosphorus concentrations at the
Royalton, Danbury, and St. Croix Falls sites. At these sites, concentrations generally remained near the MRL. At the Jordan site, concentrations generally were greatest in the spring and summer (fig. 16), which indicates runoff from agricultural areas probably contributes a substantial amount of phosphorus to this stream. At the Hastings and Red Wing site, concentrations generally were greatest in both the summer and fall. Greater concentrations during these two seasons further illustrate the importance of two different sources of phosphorus to the reach of the Mississippi River between the Hastings and Red Wing sites-runoff from agricultural areas and municipal wastewater. During the summer, when streamflows generally are greater compared to the fall and winter, a substantial amount of phosphorus may be contributed by runoff from agricultural and urban parts of the Study Unit. In contrast, during the fall, when streamflow generally is lower, municipal wastewater discharged from the TCMA probably 
Table 12. Total organic plus ammonia nitrogen loads and yields at the Mississippi, Minnesota, and St. Croix River sites in the Upper Mississippi River Basin Study Unit

[Sites are listed in downstream order; tons/d; tons per day; $\mathrm{lb} / \mathrm{mi}^{2} / \mathrm{d}$, pounds per square mile per day; \%, percent; TCMA, Twin Cities metropolitan area; NC, not computed. Loads for wastewater discharges from the TCMA were provided by C. Larson, Twin Cities Metropolitan Council]

\begin{tabular}{|c|c|c|c|c|c|c|c|c|}
\hline \multirow[b]{2}{*}{$\begin{array}{l}\text { Site } \\
\text { number } \\
\text { (shown } \\
\text { in fig. 1) }\end{array}$} & \multirow[b]{2}{*}{$\begin{array}{l}\text { U.S. Geological } \\
\text { Survey site } \\
\text { identifier }\end{array}$} & \multirow[b]{2}{*}{ Site name } & \multicolumn{3}{|c|}{ Water year 1997} & \multicolumn{3}{|c|}{ Water year 1998} \\
\hline & & & $\begin{array}{l}\text { Mean } \\
\text { daily load } \\
\text { (tons/d) }\end{array}$ & $\begin{array}{l}\text { Mean daily } \\
\text { yield } \\
\left(\mathrm{lb} / \mathrm{mi}^{2} / \mathrm{d}\right)\end{array}$ & $\begin{array}{c}\text { Prediction } \\
\text { interval }(95 \%) \\
\text { for mean daily } \\
\text { load }\end{array}$ & $\begin{array}{l}\text { Mean } \\
\text { daily load } \\
\text { (tons/d) }\end{array}$ & $\begin{array}{l}\text { Mean daily } \\
\text { yield } \\
\left(\mathrm{lb} / \mathrm{mi}^{2} / \mathrm{d}\right)\end{array}$ & $\begin{array}{c}\text { Prediction } \\
\text { interval }(95 \%) \\
\text { for mean daily } \\
\text { load }\end{array}$ \\
\hline 1 & 05267000 & $\begin{array}{l}\text { Mississippi River near Royalton, } \\
\text { Minn. }\end{array}$ & 15 & 2.6 & $14-16$ & 9.2 & 1.6 & $8.6-9.8$ \\
\hline 3 & 05288500 & $\begin{array}{l}\text { Mississippi River near Anoka, } \\
\text { Minn. }\end{array}$ & 30 & 3.1 & $27-34$ & 20 & 2.1 & $18-22$ \\
\hline \multirow[t]{2}{*}{6} & 05330000 & Minnesota River near Jordan, Minn. & 39 & 4.8 & $34-44$ & 21 & 2.6 & $19-23$ \\
\hline & & $\begin{array}{l}\text { Wastewater discharges from the } \\
\text { TCMA to Mississippi and Minne- } \\
\text { sota Rivers }\end{array}$ & 5.8 & $\mathrm{NC}$ & $\mathrm{NC}$ & 4.9 & $\mathrm{NC}$ & $\mathrm{NC}$ \\
\hline 8 & 05331580 & $\begin{array}{l}\text { Mississippi River below Lock and } \\
\text { Dam } 2 \text { at Hastings, Minn. }\end{array}$ & 81 & 4.4 & $74-88$ & 49 & 2.6 & $46-52$ \\
\hline 10 & 05333500 & St. Croix River near Danbury, Wisc. & 1.5 & 2.0 & $1.4-1.6$ & 1.0 & 1.3 & $0.9-1.0$ \\
\hline \multirow[t]{2}{*}{11} & 05340500 & $\begin{array}{l}\text { St. Croix River at St. Croix Falls, } \\
\text { Wisc. }\end{array}$ & 9.0 & 2.9 & $7.9-10.2$ & 5.3 & 1.7 & $4.7-6.0$ \\
\hline & & $\begin{array}{l}\text { Wastewater discharges from the } \\
\text { TCMA to the Mississippi and } \\
\text { St.Croix Rivers at Vermillion }\end{array}$ & 0.1 & $\mathrm{NC}$ & $\mathrm{NC}$ & 0.1 & $\mathrm{NC}$ & $\mathrm{NC}$ \\
\hline 12 & 05355250 & $\begin{array}{l}\text { Mississippi River at Red Wing, } \\
\text { Minnesota }\end{array}$ & 82 & 3.5 & $75-89$ & 57 & 2.4 & $54-61$ \\
\hline
\end{tabular}

contributes a greater percentage of the phosphorus to this reach of the Mississippi River.

Runoff as a result of spring snowmelt also may transport substantial amounts of phosphorus to the Mississippi, Minne- sota, and St. Croix Rivers (Fallon and McNellis, 2000). At the Royalton, Danbury, and St. Croix Falls sites, the greatest concentrations typically were associated with increased streamflows, which occurred in April as a result of

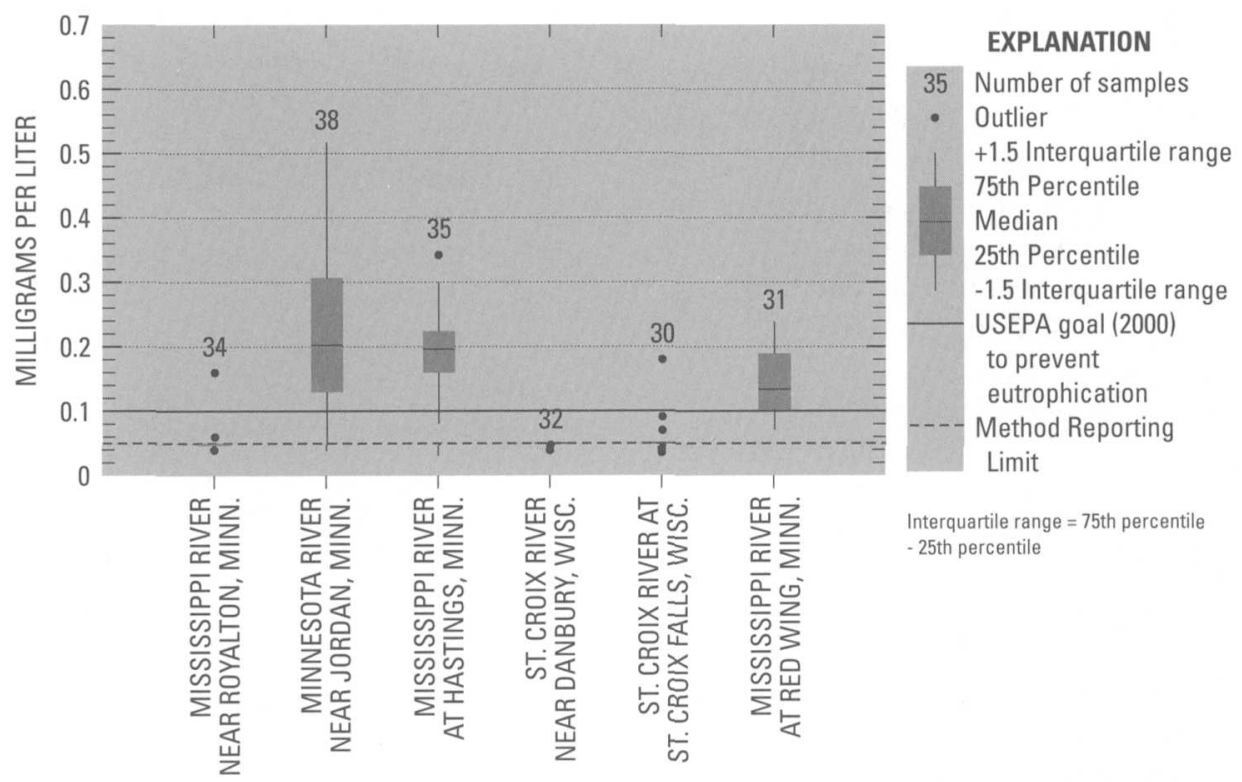

Figure 15. Total phosphorus concentrations at the Mississippi, Minnesota, and St. Croix River sites in the Upper Mississippi River Basin Study Unit, April 1996-June 1998.

snowmelt. Concentrations also increased during the spring snowmelt period at the Jordan, Hastings, and Red Wing sitemost noticeably in 1997.

\section{Dissolved orthophosphate}

Dissolved orthophosphate concentrations ranged from less than the MRL $(0.01 \mathrm{mg} / \mathrm{L})$ to $0.19 \mathrm{mg} / \mathrm{L}$ (fig. 17). The greatest median concentration was at the Hastings site, which was probably a result of contributions from the Minnesota River and wastewater discharges from the TCMA. Dissolved orthophosphate concentrations generally were less at the Red Wing site compared to the Hastings site, probably because of dilution from the St. Croix River, uptake by biota, or both.

Mean daily dissolved orthophosphate loads and yields at all the integrator sites are shown in table 14. In water year 1997, the Minnesota River near Jordan and the Mississippi River near Anoka contributed 56 and 21 percent, respectively of the mean daily dissolved orthophosphate load to the Mississippi River at Hastings. The remaining 23 percent of the mean daily load probably was contributed by 
Table 13. Total phosphorus loads and yields at the Mississippi, Minnesota, and St. Croix River sites in the Upper Mississippi River Basin Study Unit

[Sites are listed in downstream order. Tons/d, tons per day; $\mathrm{lb} / \mathrm{mi}^{2} / \mathrm{d}$, pounds per square mile per day; $\%$, percent; TCMA, Twin Cites metropolitan area; NC, not computed. Loads for wastewater discharges from the TCMA were provided by C. Larson, Twin Cities Metropolitan Council]

\begin{tabular}{|c|c|c|c|c|c|c|c|c|}
\hline \multirow[b]{2}{*}{$\begin{array}{l}\text { Site number } \\
\text { (shown in } \\
\text { fig. 1) }\end{array}$} & \multirow[b]{2}{*}{$\begin{array}{l}\text { U.S. Geological } \\
\text { Survey site } \\
\text { identifier }\end{array}$} & \multirow[b]{2}{*}{ Site name } & \multicolumn{3}{|c|}{ Water Year 1997} & \multicolumn{3}{|c|}{ Water Year 1998} \\
\hline & & & $\begin{array}{l}\text { Mean } \\
\text { daily load } \\
\text { (tons/d) }\end{array}$ & $\begin{array}{c}\text { Mean } \\
\text { daily yield } \\
\left(\mathrm{lb} / \mathrm{mi}^{2} / \mathrm{d}\right)\end{array}$ & $\begin{array}{c}\text { Prediction } \\
\text { interval }(95 \%) \\
\text { for mean daily } \\
\text { load }\end{array}$ & $\begin{array}{l}\text { Mean } \\
\text { daily load } \\
\text { (tons/d) }\end{array}$ & $\begin{array}{l}\text { Mean daily } \\
\text { yield } \\
\left(\mathrm{lb} / \mathrm{mi}^{2} / \mathrm{d}\right)\end{array}$ & $\begin{array}{c}\text { Prediction } \\
\text { interval }(95 \%) \\
\text { for mean daily } \\
\text { load }\end{array}$ \\
\hline 1 & 05267000 & $\begin{array}{l}\text { Mississippi River near Royalton, } \\
\text { Minn. }\end{array}$ & NC & NC & $\mathrm{NC}$ & NC & $\mathrm{NC}$ & $\mathrm{NC}$ \\
\hline 3 & 05288500 & Mississippi River near Anoka, Minn. & 2.9 & 0.3 & $1.0-3.6$ & 1.9 & 0.2 & $0.7-2.2$ \\
\hline \multirow[t]{2}{*}{6} & 05330000 & Minnesota River near Jordan, Minn. & 8.8 & 1.1 & $6.0-11.6$ & 4.1 & 0.7 & $3.1-5.0$ \\
\hline & & $\begin{array}{l}\text { Wastewater discharges from the } \\
\text { TCMA to Mississippi and Minne- } \\
\text { sota Rivers }\end{array}$ & 3.0 & $\mathrm{NC}$ & NC & 2.9 & NC & $\mathrm{NC}$ \\
\hline 8 & 05331580 & $\begin{array}{l}\text { Mississippi River below Lock and } \\
\text { Dam } 2 \text { at Hastings, Minn. }\end{array}$ & 13.5 & 0.72 & $11.3-15.6$ & 8.5 & 0.5 & $7.5-9.6$ \\
\hline 10 & 05333500 & St. Croix River near Danbury, Wisc. & NC & NC & $\mathrm{NC}$ & $\mathrm{NC}$ & $\mathrm{NC}$ & $\mathrm{NC}$ \\
\hline \multirow[t]{2}{*}{11} & 05340500 & $\begin{array}{l}\text { St. Croix River at St. Croix Falls, } \\
\text { Wisc. }\end{array}$ & $\mathrm{NC}$ & $\mathrm{NC}$ & $\mathrm{NC}$ & $\mathrm{NC}$ & NC & $\mathrm{NC}$ \\
\hline & & $\begin{array}{l}\text { Wastewater discharge from the } \\
\text { TCMA to Mississippi and St. } \\
\text { Croix Rivers at Vermillion }\end{array}$ & 0.2 & $\mathrm{NC}$ & NC & 0.2 & $\mathrm{NC}$ & $\mathrm{NC}$ \\
\hline 12 & 05355250 & $\begin{array}{l}\text { Mississippi River at Red Wing, Min- } \\
\text { nesota }\end{array}$ & 12.8 & 0.5 & $10.9-14.8$ & 8.8 & 0.4 & $7.8-9.9$ \\
\hline
\end{tabular}

wastewater discharges and runoff from the TCMA. In contrast, in water year 1998 , only 51 percent of the mean daily load at the Hastings site was attributed to the Jordan and Anoka sites. The remaining 49 percent of the mean daily load probably was contributed by wastewater discharges and runoff from the TCMA. The differences in loads and yields in water years 1997 and 98 may be attributable to difference in streamflow.

In the St. Croix River, mean daily loads increased by a factor of 6 in 1997 and by a factor of 5 in 1998 as the river flowed from Danbury to St. Croix Falls (table 14). The increase in loads in the St. Croix River probably was the result of tributary inflows. A study of the St. Croix Riverway during 1975 through 1983 (Graczyk, 1986) showed phosphorus yields were greater in streams tributary to the St. Croix River compared to those in the St. Croix River near Danbury, Wisconsin.

\section{Chlorophyll a and Phytoplankton}

Chlorophyll- $a$ concentrations during the growing season (June-September) for June 1996 through June 1998 ranged less than $0.1 \mathrm{mg} / \mathrm{L}$ to $31 \mathrm{mg} / \mathrm{L}$ (fig. 17 ). Median concentrations were greatest at the Jordan site. In the Mississippi River, the median chlorophyll- $a$ concentration during the growing season was greatest at the Red Wing site compared to the other sites. In the St. Croix River, the median concentration during the growing season was greater at the St. Croix Falls site compared to the Danbury site.

Median algal abundance during the 1996 growing season (table 15) ranged from 2,000 cells $/ \mathrm{mL}$ at the Royalton site to 51,000 cells $/ \mathrm{mL}$ at the Red Wing site. The median algal abundance in the Mississippi and St. Croix Rivers increased downstream. The greatest median algal abundances in these two rivers were at the Red Wing and the St. Croix Falls sites.

Diatoms generally dominated the phytoplankton community at the Royalton site (fig. 18), and also generally dominated the phytoplankton community at the Anoka and the St. Croix Falls sites. Green and blue-green algae dominated the phytoplankton community in the September 1996 samples at the Royalton and Anoka sites. At the Jordan site, the phy- toplankton community changed from primarily diatoms in April to blue-green algae from May through October. Similar changes in the composition of the phytoplankton community were measured at the Hastings, Danbury, and Red Wing sites. Streamflow during June through September 1996 was below average and approached the 25 th percentile at sites in the Study Unit. These flow conditions may have created conditions favorable for the growth of blue-green algae.

\section{Suspended Sediment}

Similar to the results for many of the other constituents, median suspendedsediment concentrations were greatest at the Jordan site (200 mg/L) (fig. 19). Suspended-sediment concentrations also were greatest at the Hastings and Red Wing sites compared to the other sites. In the St. Croix River, the median suspended-sediment concentration was about $5 \mathrm{mg} / \mathrm{L}$ at the Danbury and St. Croix Falls sites,

Mean daily suspended-sediment loads and yields (table 16) also were greater at the Jordan, Hastings, and Red Wing sites than at other sites. In water 

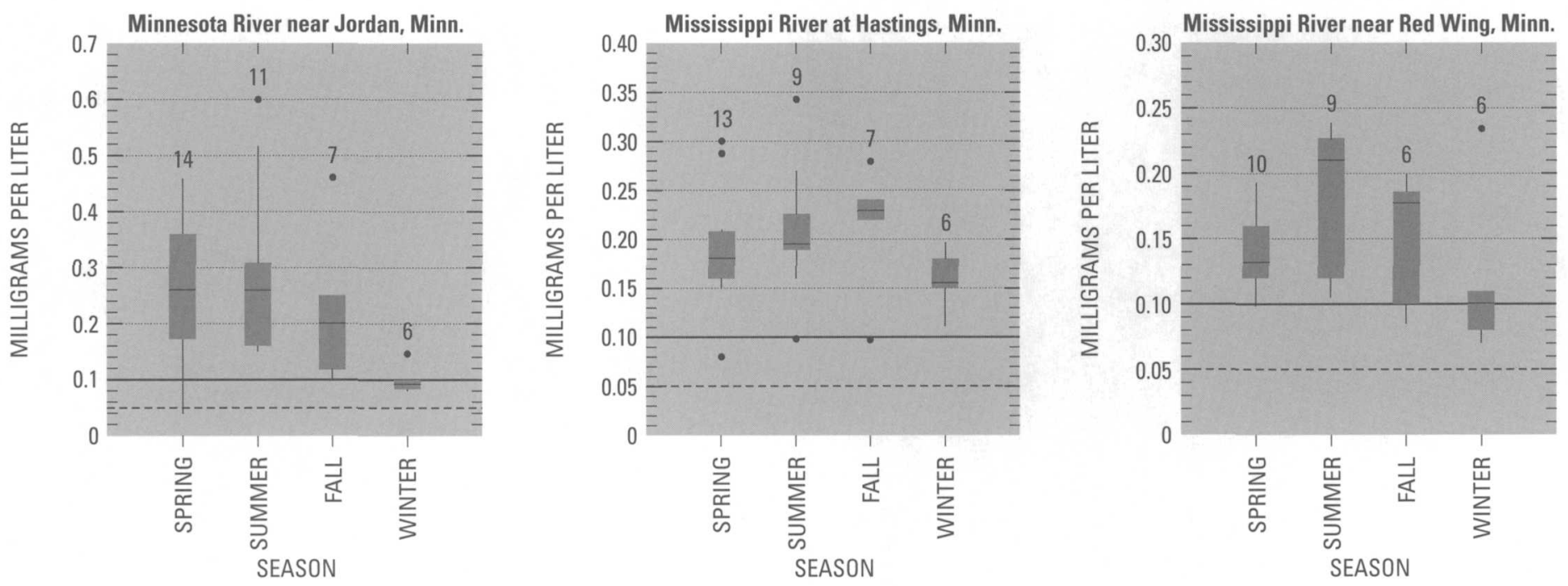

\section{EXPLANATION}

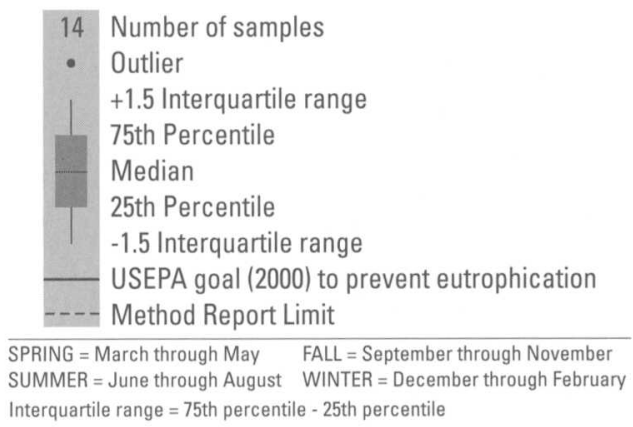

Figure 16. Seasonal variations in total phosphorus concentrations at the Mississippi and Minnesota River sites in the Upper Mississippi River Basin Study Unit, April 1996-June 1998 (note differences in concentration scales).

year 1998, the mean daily load in the Mississippi River increased about 300 tons per day between the Hastings and Red Wing sites because of inputs from the St. Croix River and other tributaries. In the St. Croix River during water year 1997, the mean daily suspended-sediment load increased by about a factor of 10 between the Danbury and St. Croix Falls sites.

\section{RELATION BETWEEN CONCENTRATIONS AND STREAMFLOW}

The source of a constituent affects its correlation with streamflow. The positive correlation between streamflow and the concentrations of dissolved nitrite plus nitrate nitrogen, total organic plus ammonia nitrogen, total phosphorus, and suspended sediment at many of the sites may be the result of constituents transported to streams by erosion, or the resuspension of settled particulate or organic matter from the streambed. The negative correlation between dissolved orthophosphate and streamflow at the Hastings site, probably is due to relatively constant inputs of phosphorus from wastewater discharges from the TCMA, which is diluted during times of greater streamflow.

The relation between constituent concentrations and streamflow varies depending upon the source of the constituent. Constituents associated with runoff from agricultural or urban lands or agricultural tile-drain flow typically have a positive relation between concentration and streamflow. Constituents primarily associated with point sources or groundwater discharge typically have a negative relation between concentration and streamflow because inputs from these sources would be diluted during periods of greater streamflows.

Correlation coefficients indicated a significant negative correlation between total phosphorus concentration and streamflow at the Danbury site (table 17). This result was unexpected. A study of nutrients in the St. Croix River Basin (Lenz and others, 2001) determined total phosphorus concentrations in streams generally increased with streamflow. Visual examination of the total phosphorus concentration and streamflow data from this site showed no relation.

Dissolved nitrite plus nitrate nitrogen concentrations in agricultural streams are expected to increase with precipitation (streamflow), so the lack of a correlation between dissolved nitrite plus nitrate concentrations and streamflow in the North Fork Crow River above Paynesville, Minnesota may be the result of dissolved nitrite plus nitrate nitrogen being 


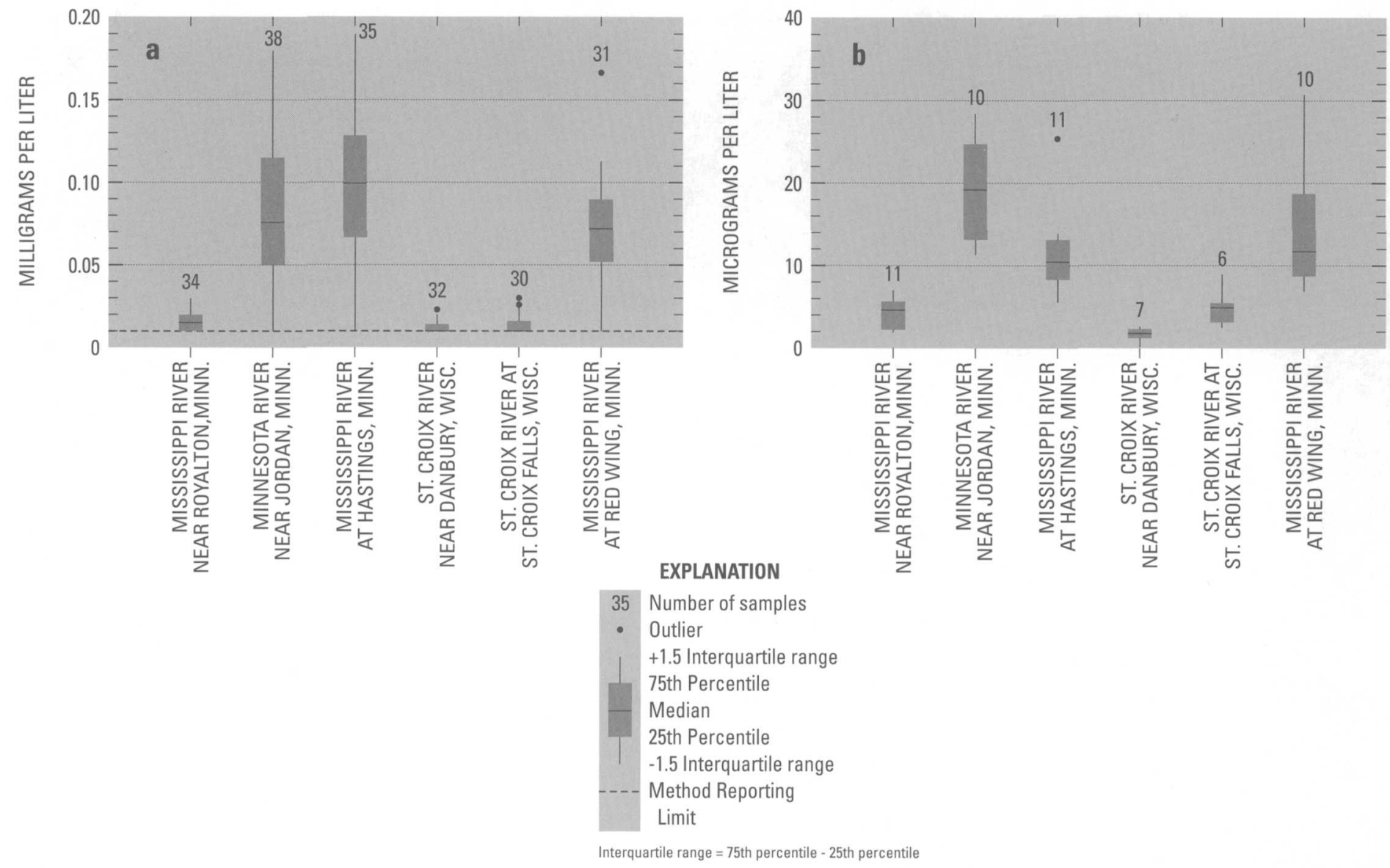

Figure 17. (a) Dissolved orthophosphate concentrations as phosphorus and (b) chlorophyll a concentrations (during the growing season) at the Mississippi, Minnesota, and St. Croix River sites in the Upper Mississippi River Basin Study Unit, April 1996-June 1998 (note differences in concentration scales).

readily leached to the ground water in this area. The soils covering this area are well drained and were developed on sandy glacial outwash. Kroening and Andrews (1997) indicated concentrations of dissolved nitrite plus nitrate nitrogen in ground water were greater in areas underlain by glacial outwash and alluvium compared to those underlain by till plains and moraines.

The general lack of a correlation between dissolved ammonia-nitrogen and chlorophyll- $a$ concentrations and streamflow was expected. Schnoebelen and others (1999) determined there was no correlation between ammonia-nitrogen concentrations and streamflow in streams in Iowa. Ammonia nitrogen is extremely reactive in the environment. It is readily assimilated by algae and other plants, strongly sorbs to particulate and organic matter, and is readily converted to nitrate under aerobic conditions. Simi- larly, the production of algae and their pigments, such as chlorophyll $a$, are affected by a variety of factors besides streamflow including light intensity, water temperature, and the availability of nutrients.

\section{INFLUENCE OF NATURAL AND ANTHROPOGENIC FACTORS ON WATER QUALITY}

Water quality in the large rivers of the Study Unit represent the cumulative quality of their tributaries. The tributaries of the Minnesota River drain primarily agricultural land, the tributaries of the St. Croix River drain primarily forested land, and the tributaries of the Mississippi River drain primarily agricultural and forested land. Dissolved nitrite plus nitrate nitrogen and dissolved orthophos- phate concentrations and yields were greatest in the streams in agricultural areas. The greatest concentrations of dissolved nitrite plus nitrate nitrogen, dissolved nitrite nitrogen, total organic plus ammonia nitrogen, total phosphorus, suspended sediment, and chlorophyll $a$ were measured at the Little Cobb River site, which represented agricultural land cover on tile-drained soils. Results also showed urban-residential land cover influenced nutrients and suspended sediment in streams. Concentrations and yields of dissolved nitrite plus nitrate nitrogen, total organic plus ammonia nitrogen, total phosphorus, dissolved orthophosphate, and suspended sediment in the urban-residential streams ranked second, being intermediate between tile-drained, agricultural area streams and forested land cover streams.

Significantly greater dissolved nitrite plus nitrate nitrogen concentrations and 
Table 14. Dissolved orthophosphate phosphorus (orthophosphate) loads and yields at the Mississippi, Minnesota, and St. Croix River sites in the Upper Mississippi River Basin Study Unit

[Sites are listed in downstream order. Tons/d, tons per day; $1 \mathrm{~b} / \mathrm{mi}^{2} / \mathrm{d}$, pounds per square mile per day; $\%$, percent; TCMA, Twin Cities metropolitan area]

\begin{tabular}{|c|c|c|c|c|c|c|c|c|}
\hline \multirow[b]{2}{*}{$\begin{array}{c}\text { Site } \\
\text { number } \\
\text { (shown in } \\
\text { fig. 1) }\end{array}$} & \multirow[b]{2}{*}{$\begin{array}{l}\text { U.S. Geological } \\
\text { Survey site } \\
\text { identifier }\end{array}$} & \multirow[b]{2}{*}{ Site name } & \multicolumn{3}{|c|}{ Water year 1997} & \multicolumn{3}{|c|}{ Water year 1998} \\
\hline & & & $\begin{array}{l}\text { Mean daily } \\
\text { load } \\
\text { (tons/d) }\end{array}$ & $\begin{array}{l}\text { Mean daily } \\
\text { yield } \\
\left(\mathrm{lb} / \mathrm{mi}^{2} / \mathrm{d}\right)\end{array}$ & $\begin{array}{c}\text { Prediction } \\
\text { interval (95\%) } \\
\text { for mean daily } \\
\text { load }\end{array}$ & $\begin{array}{l}\text { Mean daily } \\
\text { load } \\
\text { (tons } / \mathrm{d} \text { ) }\end{array}$ & $\begin{array}{c}\text { Mean daily } \\
\text { yield } \\
\left(\mathrm{lb} / \mathrm{mi}^{2} / \mathrm{d}\right)\end{array}$ & $\begin{array}{c}\text { Prediction } \\
\text { interval (95\%) } \\
\text { for mean daily } \\
\text { load }\end{array}$ \\
\hline 1 & 05267000 & $\begin{array}{l}\text { Mississippi River near Royalton, } \\
\text { Minn. }\end{array}$ & 0.39 & 0.07 & $0.28-0.50$ & 0.23 & 0.04 & $0.18-0.29$ \\
\hline 3 & 05288500 & $\begin{array}{l}\text { Mississippi River near Anoka, } \\
\text { Minn. }\end{array}$ & 1.16 & 0.12 & $0.71-1.60$ & 0.74 & 0.08 & $0.53-0.95$ \\
\hline 6 & 05330000 & $\begin{array}{l}\text { Minnesota River near Jordan, } \\
\text { Minn. }\end{array}$ & 3.06 & 0.38 & $1.5-4.6$ & 1.56 & 0.19 & $0.98-2.1$ \\
\hline & & $\begin{array}{l}\text { Wastewater discharge from the } \\
\text { TCMA to Mississippi and Min- } \\
\text { nesota Rivers }\end{array}$ & not available & & & & & \\
\hline 8 & 05331580 & $\begin{array}{l}\text { Mississippi River below Lock and } \\
\text { Dam } 2 \text { at Hastings, Minn. }\end{array}$ & 5.51 & 0.30 & $4.05-6.97$ & 4.48 & 0.24 & $3.37-5.58$ \\
\hline 10 & 05333500 & $\begin{array}{l}\text { St. Croix River near Danbury, } \\
\text { Wisc. }\end{array}$ & 0.04 & 0.05 & $0.03-0.05$ & 0.03 & 0.04 & $0.03-0.04$ \\
\hline 11 & 05340500 & $\begin{array}{l}\text { St. Croix River at St. Croix Falls, } \\
\text { Wisc. }\end{array}$ & 0.24 & 0.08 & $0.16-0.31$ & 0.15 & 0.05 & $0.11-0.19$ \\
\hline & & $\begin{array}{l}\text { Wastewater discharge from the } \\
\text { TCMA to Mississippi and St. } \\
\text { Croix Rivers at Vermillion }\end{array}$ & not available & & & & & \\
\hline 12 & 05355250 & $\begin{array}{l}\text { Mississippi River at Red Wing, } \\
\text { Minnesota }\end{array}$ & 5.9 & 0.25 & $4.1-7.7$ & 4.4 & 0.19 & $3.3-5.4$ \\
\hline
\end{tabular}

yields at the Little Cobb River site compared to the North Fork Crow River site indicated corn and soybean agriculture on tile-drained soils had a substantial effect on dissolved nitrite plus nitrate nitrogen transport to streams. In tiledrained agricultural areas, most of the dissolved nitrite plus nitrate nitrogen transport to streams occurs through tiledrain flow and little is from surface runoff (Jackson and others, 1973; Hatfield, 1996). In addition to fertilizer and livestock manure, soil nitrogen also may be a substantial source of dissolved nitrite plus nitrate nitrogen in the Study Unit. Burkart and James (1999) computed nitrate mineralized from soil organic matter was the largest potential source in the Mississippi River Basin, exceeding both commercial fertilizer and livestock manure inputs. Areas with the greatest amount of potentially mineralizable nitrate in the Study Unit included the Minnesota River Basin. Keeney and DeLuca (1993), in a study of the Des Moines River in Iowa (which is located in an environmental setting similar to the Little Cobb and Minnesota Rivers), concluded that the primary reason for nitrate contamination was enhanced mineralization of soil nitrogen resulting from tilling the soil and installing tile drainage.

Dissolved nitrite plus nitrate nitrogen was probably more readily transported from the land surface to ground water in the North Fork Crow River, which represented a naturally well-drained watershed with corn and soybean agriculture. Burkart and others (1999) have shown

Table 15. Median algal abundance in the Mississippi, Minnesota, and St. Croix Rivers in the Upper Mississippi River Basin Study Unit, June-September 1996.

[Sites are listed in downstream order]

\begin{tabular}{cclc}
\hline $\begin{array}{c}\text { Site number } \\
\text { (shown in fig. 1) }\end{array}$ & $\begin{array}{c}\text { U.S. Geological } \\
\text { Survey site identifier }\end{array}$ & \multicolumn{1}{c}{ Site name } & $\begin{array}{c}\text { Median algal abundance } \\
\text { (number of cells per milliliter) }\end{array}$ \\
\hline 1 & 05267000 & Mississippi River near Royalton, Minn. & 2,000 \\
3 & 05288500 & Mississippi River near Anoka, Minn. & 9,400 \\
6 & 05330000 & Minnesota River near Jordan, Minn. & 17,000 \\
8 & 05331580 & Mississippi River below Lock and Dam 2 at Hastings, Minn. & 10,000 \\
10 & 05333500 & St. Croix River near Danbury, Wisc. & 7,100 \\
11 & 05340500 & St. Croix River at St. Croix Falls, Wisc. & 14,000 \\
12 & 05355250 & Mississippi River at Red Wing, Minn. & 51,000 \\
\hline
\end{tabular}




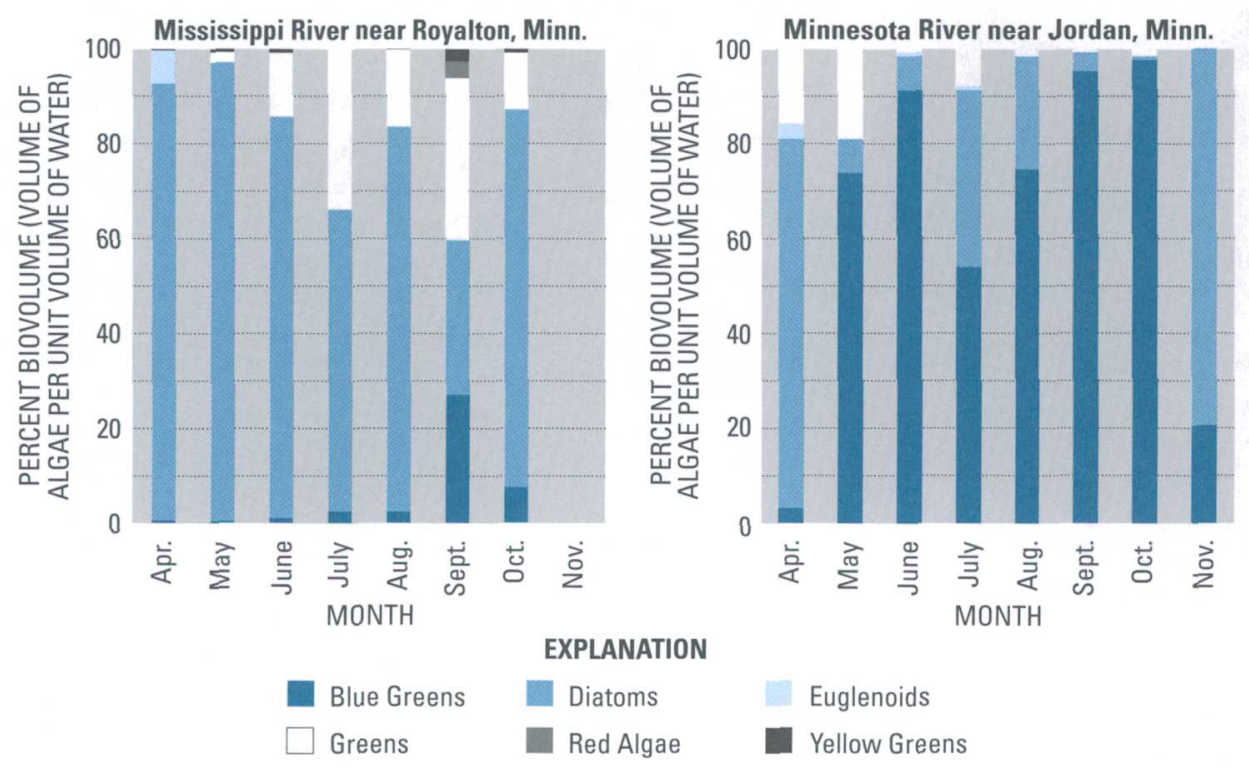

Figure 18. Seasonal variations in the phytoplankton community, by algal group, in the Mississippi River near Royalton, Minnesota, and the Minnesota River near Jordan, Minnesota, in the Upper Mississippi River Basin Study Unit, 1996.

soil characteristics, such as sandy soils, resulted in greater concentrations of dissolved nitrite plus nitrate nitrogen in the ground water. In the Study Unit, nitrate concentrations in ground water were determined to be greater in areas with more glacial outwash (Kroening and Andrews, 1997). About 38 percent of the samples from shallow ground water in a geologic setting similar to the North Fork Crow River site had dissolved nitrite plus nitrate nitrogen concentrations exceeding the MCL of $10 \mathrm{mg} / \mathrm{L}$ as nitrogen set by the USEPA for drinking water (Ruhl and others, 2000).

Nutrient and suspended-sediment concentrations and loads in the Mississippi, Minnesota, and St. Croix Rivers generally

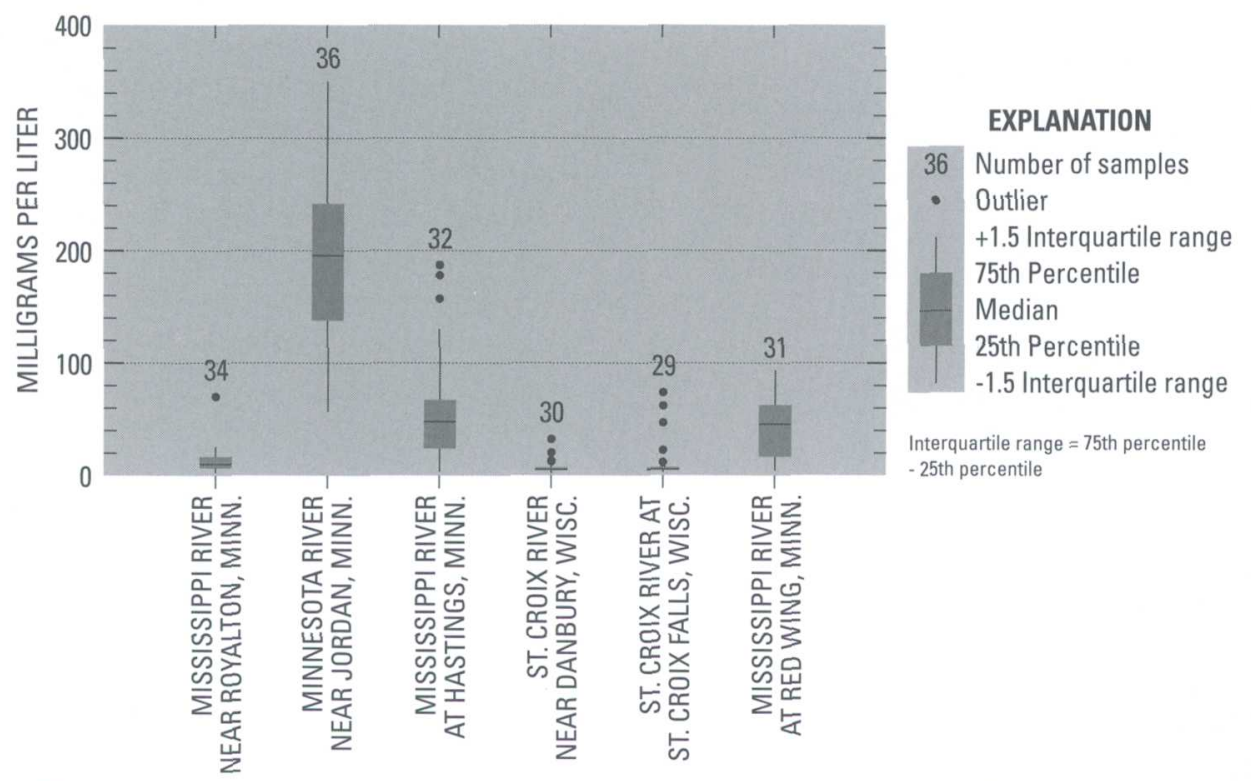

Figure 19. Suspended-sediment concentrations at the Mississippi, Minnesota, and St. Croix River sites in the Upper Mississippi River Basin Study Unit, April 1996-June 1998. reflect the primary land cover drained by the tributaries. The greatest concentrations of dissolved nitrite plus nitrate nitrogen, total organic plus ammonia nitrogen, total phosphorus, and suspended sediment generally were measured in the Minnesota River near Jordan. The concentrations of dissolved nitrite plus nitrate nitrogen, dissolved ammonia nitrogen, total organic plus ammonia nitrogen, total phosphorus, dissolved orthophosphate, and suspended sediment were less in the St. Croix River near Danbury compared to the other integrator sites because the majority of the watersheds upstream from Danbury are forested. Downstream from the TCMA, and below the confluence of the Minnesota and St. Croix Rivers, water quality in the Mississippi River results from a complex mixture of water and chemical constituents. Concentrations of nutrients and suspended sediments in the Mississippi River and decrease slightly, due to dilution downstream from the confluence with the St. Croix River (Fallon, 1998; Kroening, 2000)

Total phosphorus concentrations in of the Minnesota River and in the Mississippi River downstream from the TCMA frequently exceeded the USEPA guideline of $0.1 \mathrm{mg} / \mathrm{L}$ to prevent eutrophication (Kroening, 1998b, 2000). Phosphorus concentrations and loads to the rivers originate from both point and nonpoint sources. The major point sources are wastewater treatment facilities, whereas the major nonpoint sources are from agriculture in the Minnesota River Basin. During low streamflow conditions, more phosphorus comes from wastewater treatment facilities, whereas during high streamflow conditions, nonpoint sources dominate. Dissolved orthophosphate concentrations generally were greatest at sites downstream from wastewater discharges in the TCMA (Kroening, 1998b, 2000).

Suspended sediment adversely affects aquatic life by limiting light and covering habitat. Suspended sediment also transports nutrients, trace elements, and organic compounds attached to particles. The greatest concentration of suspended sediments in the large rivers was in the Minnesota River (Kroening, 2000). Con- 
Table 16. Suspended-sediment loads and yields at the Mississippi, Minnesota, and St. Croix River sites in the Upper Mississippi River Basin Study Unit

[Sites are listed in downstream order. Tons/d, tons per day; $\mathrm{lb} / \mathrm{mi}^{2} / \mathrm{d} ; \%$, percent; --negligible; wastewater discharge load was provided by C. Larson, Twin Cities Metropolitan Council]

\begin{tabular}{|c|c|c|c|c|c|c|c|c|}
\hline \multirow[b]{2}{*}{$\begin{array}{l}\text { Site num- } \\
\text { ber } \\
\text { (shown in } \\
\text { fig. 1) }\end{array}$} & \multirow[b]{2}{*}{$\begin{array}{l}\text { U.S. Geologi- } \\
\text { cal Survey } \\
\text { site } \\
\text { identifier }\end{array}$} & \multirow[b]{2}{*}{ Site name } & \multicolumn{3}{|c|}{ Water year 1997} & \multicolumn{3}{|c|}{ Water year 1998} \\
\hline & & & $\begin{array}{c}\text { Mean } \\
\text { daily } \\
\text { load } \\
\text { (tons/d) }\end{array}$ & $\begin{array}{c}\text { Mean daily } \\
\text { yield } \\
\left(\mathrm{lb} / \mathrm{mi}^{2} / \text { day }\right)\end{array}$ & $\begin{array}{c}\text { Prediction } \\
\text { interval (95\%) } \\
\text { for mean daily } \\
\text { load }\end{array}$ & $\begin{array}{l}\text { Mean } \\
\text { daily load } \\
\text { (tons/d) }\end{array}$ & $\begin{array}{c}\text { Mean daily } \\
\text { yield } \\
\left(\mathrm{lb} / \mathrm{mi}^{2} / \text { day }\right)\end{array}$ & $\begin{array}{c}\text { Prediction } \\
\text { interval (95\%) } \\
\text { for mean daily } \\
\text { load }\end{array}$ \\
\hline 1 & 05267000 & $\begin{array}{l}\text { Mississippi River near Royalton, } \\
\text { Minn. }\end{array}$ & 388 & 67 & $253-523$ & 151 & 26 & $121-181$ \\
\hline 3 & 05288500 & Mississippi River near Anoka, Minn. & 833 & 87 & $471-1,190$ & 457 & 48 & $325-588$ \\
\hline \multirow[t]{2}{*}{6} & 05330000 & Minnesota River near Jordan, Minn. & 6,060 & 748 & $2,560-7,340$ & 3,830 & 470 & $1,420-4,550$ \\
\hline & & $\begin{array}{l}\text { Wastewater discharges from the Twin } \\
\text { Cities metropolitan area }\end{array}$ & -. & $\mathrm{NC}$ & $\mathrm{NC}$ & -- & $\mathrm{NC}$ & $\mathrm{NC}$ \\
\hline 8 & 05331580 & $\begin{array}{l}\text { Mississippi River below Lock and } \\
\text { Dam } 2 \text { at Hastings, Minn. }\end{array}$ & 7,280 & 392 & $\begin{array}{l}4,430 \\
10,130\end{array}$ & 2,440 & 132 & $1,790-3,080$ \\
\hline 10 & 05333500 & St. Croix River near Danbury, Wisc. & 28 & 37 & $22-34$ & 18 & 24 & $14-21$ \\
\hline \multirow[t]{2}{*}{11} & 05340500 & $\begin{array}{l}\text { St. Croix River at St. Croix Falls, } \\
\text { Wisc. }\end{array}$ & 298 & 96 & $188-407$ & 108 & 35 & $75-142$ \\
\hline & & $\begin{array}{l}\text { Wastewater discharges from the Twin } \\
\text { Cities metropolitan area }\end{array}$ & & & & -- & & \\
\hline 12 & 05355250 & $\begin{array}{l}\text { Mississippi River at Red Wing, Min- } \\
\text { nesota }\end{array}$ & 4,240 & 181 & $3,110-5,380$ & 2,770 & 118 & $2,130-3,400$ \\
\hline
\end{tabular}

centrations were lower in the St. Croix River and in the upper reaches of the Mississippi River.

The addition of nutrients from wastewater treatment plants and from agricultural activities, combined with greater water temperatures and greater light penetration, stimulate algal growth. Concentrations of chlorophyll- $a$ and phytoplankton biovolume at the Jordan, Hastings, and Red Wing sites are greater than twice the concentrations measured at the Royalton site (Kroening, 2000), indicating greater phytoplankton abundance and primary production. High concentrations of nutrients, coupled with environmental conditions of sufficient light and temperature, can result in eutrophication and subsequent oxygen deficits.

Greater chlorophyll- $a$ concentrations and algal abundances in the Little Cobb River, Minnesota River near Jordan, Mississippi River at Hastings, and Mississippi River at Red Wing compared to most of the other sites coincided with greater concentrations of nitrogen and total phosphorus. The prevalence of bluegreen algae at these sites combined with increased nutrient concentrations indi- cates these streams are eutrophic (Wetzel, 1983). Total phosphorus concentrations at these sites frequently exceeded the goal set by the USEPA (1986) to prevent eutrophication. Phosphorus typically is thought to be the limiting nutrient for algal growth in fresh water (Cole, 1983). However, phosphorus may not be the only factor limiting algal growth in these streams. A recent study of Lake Pepin (James and others, 2000) analyzed alkaline phosphotase activity and soluble reactive phosphorus. Alkaline phosphotase is an enzyme produced by phytoplankton when phosphorus limits growth. James and others (2000) reported that alkaline phosphotase activity in Lake Pepin was extremely low, and soluble reactive phosphorus concentrations in the lake were relatively great. James and others (2000) concluded that phytoplankton growth in the lake was not limited by phosphorus. Other factors, such as discharge and light, also influence phytoplankton growth in streams (Allan, 1995). Algal growth in these streams may be light limited due to increased suspended-sediment concentrations. There also may be some self shading when phytoplankton are abundant.

The MCL for nitrate of $10 \mathrm{mg} / \mathrm{L}$ as nitrogen set by the USEPA for drinking water was exceeded in some samples analyzed from the Minnesota River near Jordan. The primary surface-water supply intakes for the TCMA are located on the Mississippi River near Fridley, Minnesota, which is upstream of the confluence with the Minnesota River. Most of the dissolved nitrite plus nitrate nitrogen transported to the Mississippi River in the Study Unit was from the Minnesota River, which is transported to downstream communities. Within the Study Unit, dissolved nitrite plus nitrate nitrogen concentrations in the Mississippi River did not decrease substantially between Hastings and Red Wing, and dissolved nitrite plus nitrate loads along this same reach increased. Analysis of longterm data from 1984-93 (Kroening and Andrews, 1997) also showed nitrate concentrations in the Mississippi River do not decrease substantially downstream from the Study Unit. Concentrations near the outlet of Lake Pepin remained about 1 to $2 \mathrm{mg} / \mathrm{L}$ greater than concentrations at sites upstream from the Minnesota River. 
Table 17. Kendall tau-b correlation coefficients for nutrient, chlorophyll- $a$, and suspended-sediment concentrations and streamflow, water years 1996-98, by stream site

[Sites are shown in downstream order. Statistically significant correlations less than the 0.05 significance levels are shown in bold type. Explanation of values in table (given for dissolved nitrite plus nitrate nitrogen at site number 1): -0.018 , correlation coefficient; $0.896, p$-value; 32 , number of observations]

\begin{tabular}{|c|c|c|c|c|c|c|c|c|}
\hline $\begin{array}{l}\text { Site num- } \\
\text { ber (shown } \\
\text { in fig. 1) }\end{array}$ & Site Name & $\begin{array}{l}\text { Dissolved } \\
\text { nitrite plus } \\
\text { nitrate } \\
\text { nitrogen }\end{array}$ & $\begin{array}{l}\text { Dissolved } \\
\text { ammonia } \\
\text { nitrogen }\end{array}$ & $\begin{array}{l}\text { Total organic } \\
\text { plus ammo- } \\
\text { nia nitrogen }\end{array}$ & $\begin{array}{l}\text { Dissolved } \\
\text { orthophos- } \\
\text { phorus }\end{array}$ & $\begin{array}{c}\text { Total } \\
\text { phosphorus }\end{array}$ & Chlorophyll $a$ & $\begin{array}{l}\text { Suspended } \\
\text { sediment }\end{array}$ \\
\hline \multirow[t]{3}{*}{1} & \multirow{3}{*}{$\begin{array}{l}\text { Mississippi River near } \\
\text { Royalton, Minn. }\end{array}$} & -0.018 & 0.189 & 0.379 & 0.176 & -0.053 & -0.119 & 0.280 \\
\hline & & 0.896 & 0.134 & 0.002 & 0.162 & 0.682 & 0.442 & 0.026 \\
\hline & & 32 & 32 & 32 & 32 & 32 & 23 & 32 \\
\hline \multirow[t]{3}{*}{2} & \multirow{3}{*}{$\begin{array}{l}\text { North Fork Crow River } \\
\text { above Paynesville, } \\
\text { Minn. }\end{array}$} & 0.132 & 0.062 & 0.555 & 0.510 & 0.550 & 0.128 & -0.193 \\
\hline & & 0.272 & 0.610 & 0.000 & 0.000 & 0.000 & 0.396 & 0.114 \\
\hline & & 35 & 35 & 35 & 35 & 35 & 24 & 35 \\
\hline \multirow[t]{3}{*}{4} & \multirow{3}{*}{$\begin{array}{l}\text { Shingle Creek at Queen } \\
\text { Avenue in Minneapo- } \\
\text { lis, Minn. }\end{array}$} & -0.163 & -0.205 & 0.187 & 0.171 & 0.353 & -0.039 & -0.346 \\
\hline & & 0.070 & 0.022 & 0.034 & 0.056 & 0.000 & 0.424 & 0.000 \\
\hline & & 59 & 59 & 59 & 59 & 59 & 39 & 58 \\
\hline \multirow[t]{3}{*}{5} & \multirow{3}{*}{$\begin{array}{l}\text { Little Cobb River near } \\
\text { Beauford, Minn. }\end{array}$} & 0.483 & 0.048 & 0.202 & 0.060 & 0.297 & -0.011 & 0.335 \\
\hline & & 0.000 & 0.631 & 0.042 & 0.542 & 0.003 & 0.984 & 0.001 \\
\hline & & 50 & 50 & 49 & 50 & 49 & 37 & 50 \\
\hline \multirow[t]{3}{*}{6} & \multirow{3}{*}{$\begin{array}{l}\text { Minnesota River near } \\
\text { Jordan, Minn. }\end{array}$} & 0.333 & 0.043 & 0.225 & 0.146 & 0.354 & -0.120 & 0.280 \\
\hline & & 0.004 & 0.719 & 0.037 & 0.208 & 0.002 & 0.424 & 0.017 \\
\hline & & 37 & 37 & 37 & 37 & 37 & 24 & 36 \\
\hline \multirow[t]{3}{*}{7} & \multirow{3}{*}{$\begin{array}{l}\text { Nine Mile Creek above } \\
\text { James Circle at Bloom- } \\
\text { ington, Minn. }\end{array}$} & -0.243 & 0.103 & 0.347 & 0.231 & 0.372 & 0.000 & 0.105 \\
\hline & & 0.012 & 0.285 & 0.000 & 0.013 & 0.000 & 1.00 & 0.276 \\
\hline & & 52 & 52 & 52 & 52 & 52 & 39 & 52 \\
\hline \multirow[t]{3}{*}{8} & \multirow{3}{*}{$\begin{array}{l}\text { Mississippi River below } \\
\text { Lock and Dam } 2 \text { at } \\
\text { Hastings, Minn. }\end{array}$} & 0.236 & -0.071 & 0.295 & -0.452 & 0.041 & -0.009 & 0.597 \\
\hline & & 0.583 & 0.060 & 0.019 & 0.000 & 0.749 & 0.976 & 0.000 \\
\hline & & 32 & 32 & 32 & 32 & 32 & 22 & 29 \\
\hline \multirow[t]{3}{*}{9} & \multirow{3}{*}{$\begin{array}{l}\text { Namekagon River at } \\
\text { Leonards, Wisc. }\end{array}$} & 0.128 & 0.329 & 0.630 & -0.073 & -0.229 & 0.113 & 0.254 \\
\hline & & 0.328 & 0.011 & 0.000 & 0.583 & 0.079 & 0.610 & 0.056 \\
\hline & & 30 & 30 & 30 & 30 & 30 & 14 & 29 \\
\hline \multirow[t]{3}{*}{10} & \multirow{3}{*}{$\begin{array}{l}\text { St. Croix River near Dan- } \\
\text { bury, Wisc. }\end{array}$} & 0.266 & 0.037 & 0.447 & -0.100 & -0.439 & -0.179 & 0.205 \\
\hline & & 0.031 & 0.772 & 0.000 & 0.424 & 0.000 & 0.430 & 0.110 \\
\hline & & 33 & 33 & 30 & 33 & 33 & 13 & 31 \\
\hline \multirow[t]{3}{*}{11} & St. Croix River at St. & -0.143 & 0.154 & 0.624 & 0.238 & 0.071 & 0.067 & 0.428 \\
\hline & Croix Falls, Wisc. & 0.259 & 0.238 & 0.000 & 0.068 & 0.597 & 0.764 & 0.001 \\
\hline & & 30 & 30 & 30 & 30 & 30 & 15 & 29 \\
\hline \multirow[t]{3}{*}{12} & Mississippi River at Red & 0.274 & 0.000 & 0.258 & -0.148 & 0.176 & 0.000 & 0.369 \\
\hline & Wing, Minn. & 0.032 & 1.00 & 0.044 & 0.251 & 0.171 & 1.00 & 0.004 \\
\hline & & 31 & 31 & 31 & 31 & 31 & 31 & 31 \\
\hline
\end{tabular}

\section{SUMMARY AND CONCLUSIONS}

Streams were sampled in the Upper Mississippi River Basin Study Unit from 1996 through 1998 to describe the distribution of nutrients, chlorophyll $a$, phytoplankton, and suspended sediment, and the influence of natural and anthropogenic factors on concentrations, loads, and yields. The Study Unit includes the drainage of the Mississippi River from its source in northern Minnesota to the outlet of Lake Pepin, a natural lake on the river. During the study period, streamflows were greater than average in 1996 and 1997 and near-average in 1998 compared to the previous 25 years.

Agricultural land cover, particularly on tile-drained soils, had the greatest influence on nutrients, chlorophyll $a$, and suspended sediment in streams in the Study Unit. The greatest con- centrations and yields of total nitrogen, dissolved nitrite plus nitrate nitrogen, dissolved nitrite nitrogen, total organic plus ammonia nitrogen, total phosphorus, and suspended sediment were measured at the Little Cobb River site, which represented agricultural land cover on tile-drained soils. Total nitrogen yields were greater at the Little Cobb River site than at the North Fork Crow River site, which represented agricultural land cover on naturally well-drained soils.

Urban-residential land cover also influenced nutrients and suspended sediment in streams. Concentrations of total nitrogen, dissolved nitrite plus nitrate nitrogen, total organic plus ammonia nitrogen, total phosphorus, dissolved orthophosphate, and suspended sediment in streams representing urban-residential land cover were intermediate between concentrations and yields 
at sites representing agricultural and forested land cover.

Nutrients and suspended sediment in the Mississippi, Minnesota, and St. Croix Rivers generally reflect the influence of primary land cover in drainage areas of streams tributary to these rivers. The greatest concentrations of total nitrogen, dissolved nitrite plus nitrate nitrogen, total organic plus ammonia nitrogen, total phosphorus, and suspended sediment generally were measured at the Jordan site. These greater concentrations probably were the result of contributions from tributaries in agricultural areas. The least concentrations of dissolved nitrite plus nitrate nitrogen, dissolved ammonia nitrogen, total organic plus ammonia nitrogen, total phosphorus, dissolved orthophosphate, and suspended sediment generally were measured at the Danbury site, probably as the result of contributions from tributaries in forested areas.

Total nitrogen, dissolved nitrite plus nitrate nitrogen, dissolved ammonia nitrogen, total phosphorus, dissolved orthophosphate, and suspended-sediment concentrations and loads in the Mississippi River increased most substantially downstream of the confluence with the Minnesota River. Increases in concentrations and loads were the result of contributions from the Minnesota River. Greater concentrations and loads of dissolved ammonia nitrogen and dissolved orthophosphate at the Hastings site probably were caused by wastewater discharges from the Twin Cities metropolitan area (TCMA) and contributions from the Minnesota River. The median dissolved ammonia nitrogen concentration at the Hastings site was about one-half the median concentration from water years 1984 through 1993. This decrease can be attributed to reduced ammonia concentrations in municipal wastewater discharged from the TCMA.

In the St. Croix River, total nitrogen, dissolved nitrite plus nitrate nitrogen, and total organic plus ammonia nitrogen concentrations were significantly greater at the St. Croix Falls site compared to the Danbury site. Nutrient and suspended-sediment loads and yields in the St. Croix River increase downstream from the Danbury site to the St. Croix Falls site.

Most sites had seasonal variations in dissolved nitrite plus nitrate nitrogen and dissolved ammonia nitrogen concentrations. Concentrations were greatest in the winter and spring and least during the summer and fall. The greatest dissolved nitrite plus nitrate nitrogen concentrations at the Little Cobb River, Jordan, Hastings and Red Wing sites occurred during the spring and summer. These seasonal variations in dissolved nitrite plus nitrate nitrogen concentrations may be the result of nitrogen cycling in the soils, as well as crop uptake and hydrologic conditions. The greatest concentrations of dissolved ammonia nitrogen occurred in the winter and spring. Greater concentrations during this period may be the result of reduced uptake by biota or reduced nitrification due to colder water temperatures. Inputs from leaking sewers or septic systems, from livestock feedlots, or from ground-water discharge also may increase ammonia nitrogen concentration in streams during the winter as a result of reduced streamflow.

The maximum contaminant level for nitrate of $10 \mathrm{mg} / \mathrm{L}$ as nitrogen set by the U.S. Environmental Protection Agency (1986) for drinking water was exceeded in 20 percent of the samples analyzed from the Little Cobb River site, and in 11 percent of the samples analyzed from the Jordan site.

The greatest concentrations of chlorophyll $a$ and algal abundances generally were at the Little Cobb River, Jordan, Hastings, and Red Wing sites. Greater concentrations and algal abundances at these locations may have been the result of increased nitrogen and phosphorus concentrations. Total phosphorus concentrations at these sites most frequently exceeded the U.S. Environmental Protection Agency (1992) goal of $0.1 \mathrm{mg} / \mathrm{L}$ to prevent eutrophication. The phytoplankton community at these sites primarily was dominated by blue-green algae during the summer. In contrast, at most of the other sites, the phytoplankton community was dominated by diatoms.

\section{REFERENCES}

Allan, J.D., 1995, Stream ecologyStructure and function of running waters: London, England, Chapman and Hall, $388 \mathrm{p}$.

Anderson, H.W., Jr., 1989, Effects of agriculture on quality of water in surficial sand-plain aquifers in Douglas, Kandiyohi, Pope, and Stearns Counties, Minnesota: U.S. Geological Survey Water-Resources Investigations Report 87-4040, $52 \mathrm{p}$.

Borchert, J.R., and Gustafson, N.C., 1980, Atlas of MinnesotaResources and settlement, 3rd ed.: Minneapolis, Minn., Center for Urban Development and Regional
Affairs, 309 p.

Burkart, M.R., and James, D.E., 1999, Agricultural-nitrogen contributions to hypoxia in the Gulf of Mexico: Journal of Environmental Quality, v. 28, p. 850-859.

Burkart, M.R., Kolpin, D.W., Jaquis, R.J., and Cole, K.J., 1999, Agrichemicals in ground water of the Midwestern USA-Relations to soil characteristics: Journal of Environmental Quality, v. 28, p. 1908-1915.

Capel, P.D., and Larson, S.J., 1996, Evaluation of selected information on splitting devices for water samples: U.S. Geological Survey WaterResources Investigations Report 954141, $103 \mathrm{p}$.
Cole, G.A., 1983, Textbook of Limnology: Prospect Heights, Ill., Waveland Press, Inc., $400 \mathrm{p}$.

Cummins, JF., 1965, Soil survey of Waseca County, Minnesota: U.S. Department of Agriculture series 1961 , no. 24, 84 p., 72 sheets.

Edwards, T.K., and Glysson, G.D., 1988, Field methods for measurement of fluvial sediment: U.S. Geological Survey Open-File Report 86-531, $118 \mathrm{p}$.

Fallon, J.D., 1998, Pesticides and pesticide metabolites in selected streams of the Upper Mississippi River Basin, 1997 [abs.]: Minnesota Water '98Protecting Minnesota's Water Supplies, 6th Biennial Conference on 
Minnesota Water Issues, May 5-6, 1998, University of Minnesota, Water Resources Research Center, $\mathrm{p}$. 92.

Fallon, J.D., Fong, A.L., and Andrews, W.J., 1997, Water-Quality Assessment of Part of the Upper Mississippi River Basin, Minnesota and Wisconsin--Pesticides in Streams, Streambed Sediment, and Ground Water, 1974-94: U.S. Geological Survey Water-Resources Investigations Report 97-4141, 53 p.

Fallon, J.D., and McNellis, R.P., 2000, Nutrients and suspended sediment in snowmelt runoff from part of the Upper Mississippi River Basin, Minnesota and Wisconsin, 1997: U.S. Geological Survey Water-Resources Investigations Report 00-4165, 23 p.

Fenneman, N.M., 1938, Physiography of the eastern United States: New York, McGraw-Hill Book Company, 714 p.

Fishman, M.J. (ed.), 1993, Methods of analysis by the U.S. Geological Survey National Water-Quality Laboratory-Determination of inorganic and organic constituents in water and fluvial sediments: U.S. Geological Survey Open-File Report 93-125, 217 p.

Gilliom, R.J., Alley, W.M., and Gurtz, M.E., 1995, Design of the National Water-Quality Assessment Program-Occurrence and distribution of water-quality conditions: U.S. Geological Survey Circular 1112, 33 p.

Goldstein, R.M., Lee, K.E., Talmage, Philip, Stauffer, J.C., and Anderson, J.P., 1999, Relation of fish-community composition to environmental factors and land use in part of the Upper Mississippi River Basin, 1995-97: U.S. Geological Survey Water- Resources Investigations Report 99-4034, 32 p.

Graczyk, D.J., 1986, Water quality in the St. Croix National Scenic Riverway, Wisconsin: U.S. Geological Survey Water-Resources Investigations Report 85-4319, 48 p.

Green, J.C., 1982, Geology of Keweenan extrusive rocks, in Wold, R.J., and Hinze, W.J., eds., Geology and Tec- tonics of the Lake Superior Basin: The Geological Society of America, Memoir 156, p. 47-55.

Hahn, G.J., and Meeker, W.Q., 1991, Statistical intervals- A guide for practitioners: New York, John Wiley and Sons, Inc., 392 p.

Hatfield, J. L., 1996, Accomplishments in watershed management-Examples from Walnut Creek watershed in Iowa: Proceedings of the Clean Water-Clean Environment in The 21st Century Conference-_Volume IV, Accomplishments, Challenges, and Perspectives, March 5-8, 1995, Kansas City, Missouri, p. 79-82.

Helsel, D. R., and Hirsch, R.M., 1992, Statistical methods in water resources: Amsterdam, The Netherlands, Elsevier Science Publishing Company, $522 \mathrm{p}$.

Hem, J.D., 1985, Study and interpretation of the chemical characteristics of natural water, $3 \mathrm{~d}$ ed.: U.S. Geological Survey Water-Supply Paper 2254, 263 p.

Hitt, K.J., 1994, Refining 1970's landuse data with 1990 population data to indicate new residential development: U.S. Geological Survey WaterResources Investigations Report 944250, 15 p.

Hobbs, H.C., and Goebel, J.E., 1982, Geologic map of Minnesota-Quaternary geology: Minnesota Geological Survey Map Series S-1, 1 sheet.

Holmberg, K.L., Perry, J., Ferrin, R.S., and Sparrow, D.L., 1997, Water resources management plan-St. Croix National Scenic Riverway, Minnesota and Wisconsin, unpaged.

Jackson, W.A., Asmussen, L.E., Hauser, E.W., and White, A.W., 1973,

Nitrate in surface and subsurface flow from a small agricultural watershed: Journal of Environmental Quality, v. 2, p. 480-482.

James, W.F., Barko, J.W., and Eakin, H.L., 2000, Synthesis of phosphorus/seston fluxes and phytoplankton dynamics in Lake Pepin (Upper Mississippi River), 1994-1996: Final report prepared by the U.S. Army Waterways Experiment Station, Eau Galle Aquatic Ecology Laboratory,
Spring Valley, Wisc., for Metropolitan Council Environmental Services, St. Paul, Minnesota, 73 p.

Justic, D., Rabalais, N.N., Turner, E.R., and Wiseman, W.J., 1993, Seasonal coupling between riverborne nutrients, net productivity, and hypoxia: Marine Pollution Bulletin, v. 26. no. 4, p. 184-189.

Keeney, D.R., and DeLuca, T.H., 1993, Des Moines River nitrate in relation to watershed agricultural practices1945 versus 1980s: Journal of Environmental Quality, v. 22, p. 267-272.

Kroening, S.E., 1994, Phosphorus trends in the Upper Mississippi River Basin: University of Minnesota, M.S. thesis, $220 \mathrm{p}$.

_ $1998 \mathrm{a}$, Nitrate concentrations, loads, and yields in streams in part of the Upper Mississippi River Basin, Minnesota and Wisxonsin, 1996-98 [abs.]: Minnesota Water '98-Protecting Minnesota's Water Supplies, 6 th Biennial Conference on Minnesota's Critical Water Issues, May 56, 1998, University of Minnesota, Water Resources Research Center, $\mathrm{p}$ 67.

,1998b, Nutrient sources within the Upper Mississippi River Basin, Minnesota and Wisconsin, 1991-93: U.S.Geological Survey Fact Sheet FS-121-98, 4 p.

2000, Nutrients, suspended sediment, and algae in streams in part of the Upper Mississippi River Basin, 1984-98 [abs.]: Minnesota Water 2000_A watershed year-Looking back, planning ahead, 7th Bienial Conference, April 25-26, 2000, University of Minnesota, Water Resources Research Center, p. 46.

Kroening, S.E., and Andrews, W.J., 1997, Water-quality assessment of part of the Upper Mississippi River Basin, Minnesota and WisconsinNitrogen and phosphorus in streams, streambed sediment, and ground water, 1971-94: U.S. Geological Survey Water-Resources Investigations Report 97-4107, 61 p.

Larson, C.E., Johnson, D.K., Flood, R.J., Meyer, M.L., O'Dea, T.J., and Schellhaas, S.M., 2002, Lake Pepin 
phosphorus study, 1994-1998-

Effects of phosphorus loads on the water quality of the Mississippi

River, Lock and Dam 1 through Lake Pepin: St. Paul, Minn., Metropolitan Council Environmental Services, 84 p.

Lee, K.E., and ZumBerge, Jeremy, 2000, Phytoplankton community composition in streams in part of the Upper Mississippi River Basin, April-September 1996 [abs.]: Minnesota Water 2000_A watershed year-Looking back, planning ahead, 7th Biennial Conference, April 25-26, 2000, University of Minnesota, Water Resources Research Center, p. 46.

Lenz, B.L., Robertson, D.M., Fallon, J.D., and Ferrin, Randy, 2001, Nutrient and suspended-sediment concentrations and loads and benthicinvertebrate data for tributaries to the St. Croix River, Wisconsin and Minnesota, 1997-99: U.S. Geological Survey Water-Resources Investigations Report 01-4162, 57 p.

Litke, D.W., 1999, Review of phosphorus control measures in the United States and their effects on water quality: U.S. Geological Survey WaterResources Investigations Report 994007, 38 p.

Metropolitan Waste Control Commission, 1993a, Mississippi River phosphorus study report-Water quality of the Mississippi River and its tributaries (1976-1991): St. Paul, Minnesota, $18 \mathrm{p}$.

,1993b, Mississippi River phosphorus study report-Point and nonpoint source phosphorus contributions: St. Paul, Minnesota, $66 \mathrm{p}$.

Minnesota Department of Transportation, 1993, River transportation in Minnesota, Ports and Waterways Section: St. Paul, Minnesota, 69 p.

Minnesota Environmental Quality Board, 2000, Minnesota watermarks gauging the flow of progress 2000 2010: St. Paul, Minnesota, 49 p.

Minnesota Pollution Control Agency, 1989, Review of water-quality conditions in Lake Pepin for the summer of 1988: St. Paul, Minnesota, 50 p.
Mueller, D.K., Martin, J.D., and Lopes, T.J., 1997, Quality-control design for surface- water sampling in the National Water-Quality Assessment Program: U.S. Geological Survey Open-File Report 97-223, 17 p.

Ojakangas, R.W., and Matsch, C.L., 1982, Minnesota's geology: Minneapolis, Minnesota, University of Minnesota Press, 255 p.

Olcott, P.G., 1992, Ground-water atlas of the United States, Segment 9: U.S. Geological Survey Hydrologic Investigations Atlas 730-J, 31 p., scales $1: 2,500,000$ and 1:500,000.

Patton, C.J., and Truitt, E.P., 1992, Methods of analysis by the U.S. Geological Survey National Water-Quality Laboratory-Determination of total phosphorus by a kjeldahl digestion method and an automated colorimetric finish that includes dialysis: U.S. Geological Survey Open-File Report 92-146, 39 p.

Payne, G.A., 1994, Sources and transport of sediment, nutrients, and oxygen-demanding substances in the Minnesota River Basin, 1989-92: U.S. Geological Survey WaterResources Investigations Report 934232, 71 p.

Quade, H.W., Boyum, K.W., Braaton, D.O., Gordon, Donald, Pierce, C.L., Silis, A.Z., Smith, D.R., and Thompson, B.C., 1980, The nature and effects of county drainage ditches in South Central Minnesota: University of Minnesota, Water Resources Research Center, Bulletin 105, 121 p.

Rabalais, N.N., Turner, R.E., Wiseman, W.J., Justic, D., Dortch, Q., and Gupta, B.S., 1994, Hypoxia on the Louisiana Shelf and system responses to nutrient changes in the Mississippi River-A brief synopsis, in National Oceanic and Atmospheric Administration, Nutrientenhances coastal ocean productivity: Proceedings of the 1994 synthesis workshop, Baton Rouge, LA.

Randall, G.W., 1998, Implications of dry and wet cycles on nitrate loss to subsurface tile drainage: Proceedings of the 7 th annual drainage symposium in the 21 st Century, Orlando, Florida,
March 8-10, 1998, p. 53-60.

Rantz, S.E., and others, 1982, Measurement and computation of streamflow: U.S. Geological Survey Water-Supply Paper 2175, 631 p.

Ruhl, J.F., Fong, A.L., Hanson, P.E., and Andrews, W.J., 2000, Water-quality assessment of part of the Upper Mississippi River Basin, Minnesota and Wisconsin-Ground-water quality in an agricultural area of Sherburne County, Minnesota, 1998: U.S. Geological Survey Water-Resources Investigations Report 00-4107, 33 p.

Schnoebelen, D. J., Becher, K.D., Bobier, M.W., and Wilton, Thomas, 1999, Selected nutrients and pesticides of the Eastern Iowa Basins, 1970-95: U.S. Geological Survey Water-Resources Investigations Report 99-4028, 65 p.

Shelton, L.R., 1994, Field guide for collecting and processing stream-water samples for the National WaterQuality Assessment Program: U.S. Geological Survey Water-Resources Investigations Report 94-455. 42 p.

Stark, J.R., Andrews, W.J., Fallon, J.D., Fong, A.L., Goldstein, R.M., Hanson, P.E., Kroening, S.E., and Lee, K.E., 1996, Water-quality assessment of part of the Upper Mississippi River Basin, Minnesota and Wisconsin-Environmental setting and study design: U.S. Geological Survey Water-Resources Investigations Report 96-4098, 62 p.

Stark, J.R., Fallon, J.D., Fong, A.L., Goldstein, R.M., Hanson, P.E., Kroening, S.E., and Lee, K.E., 1999, Water-quality assessment of part of the Upper Mississippi River Basin, Minnesota and Wisconsin-Design and implementation of water-quality studies, 1995-98: U.S. Geological Survey Water-Resources Investigations Report 99-4135, 85 p.

Tchobanoglous, George, 1991, Wastewater Engineering-Treatment, disposal, reuse: New York, McGrawHill, 1334 p.

Turner, Eugene, and Rabalais, N.N., 1994, Coastal eutrophication near the Mississippi River delta: Nature, v. 368, p. 619-621. 
Wetzel, R.G., 1983, Limnology: Philadelphia, Pennsylvania, Saunders College Publishing, 767 p.

Wright, H.E., Jr., 1972, Quaternary history of Minnesota, in Sims, P.K., and Morey, G.B. (eds.), Geology of Minnesota-A centennial volume: $\mathrm{St}$.

Paul, Minnesota, Minnesota Geological Survey, p. 515-547.

U.S. Environmental Protection Agency,
1986, Quality criteria for water 1986: U.S. Environmental Protection Agency, EPA-440-5-86-001.

U.S. Environmental Protection Agency, 1992, Method 445.0-In vitro determination of chlorophyll $a$ and phaeophytin in marine and freshwater phytoplankton by fluorescence, in Methods for determination of chemical substances in marine and estua- rine environmental samples: U.S. Environmental Protection Agency Report 600/R-92/ 121, p. 445.0-1445.0-9.

U.S. Environmental Protection Agency, 2000, Drinking water standards and health advisories: U.S. Environmental Protection Agency Report EPA 822--B-00-001, 12 p. 
